
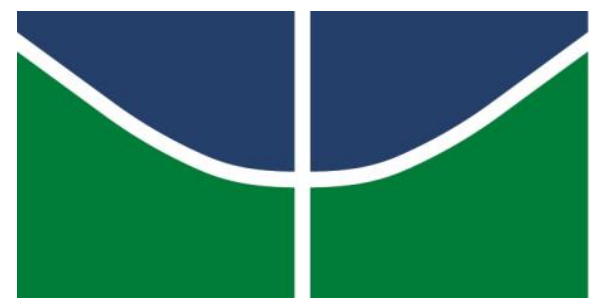

UNIVERSIDADE DE BRASÍLIA

INSTITUTO DE CIENCIAS HUMANAS

PROGRAMA DE PÓS-GRADUAÇÃO EM GEOGRAFIA

MESTRADO EM GEOGRAFIA

\title{
A PAISAGEM DA BACIA HIDROGRAFICA DO RIO CORRENTE- PI E SUAS MODIFICAÇÕES PELA LENTE DAS CRIANÇAS DO ENSINO FUNDAMENTAL
}

RAFAELA ARAÚJO DO NASCIMENTO

BRASÍLIA-DF

2016 
RAFAELA ARAÚJO DO NASCIMENTO

\section{A PAISAGEM DA BACIA HIDROGRAFICA DO RIO CORRENTE-PI E SUAS MODIFICAÇÕES PELA LENTE DAS CRIANÇAS DO ENSINO FUNDAMENTAL}

Dissertação de Mestrado apresentada ao Programa de PósGraduação em Geografia da Universidade de Brasília como requisito parcial para obtenção do título de Mestre em Geografia.

Orientador: Prof. Dr. Valdir Steinke

Brasília - DF

2016 


\title{
A PAISAGEM DA BACIA HIDROGRAFICA DO RIO CORRENTE-PI E SUAS MODIFICAÇÕES PELA LENTE DAS CRIANÇAS DO ENSINO FUNDAMENTAL
}

Dissertação apresentada como requisito parcial para obtenção do título de Mestre em Geografia pelo Programa de Pós-Graduação em Geografia da Universidade de Brasília,

Dissertação defendida em: 22/02/2016.

\author{
Banca Examinadora
}

Prof. Dr. Valdir Adilson Steinke

Departamento de Geografia, Universidade de Brasília

(Orientador)

Prof. Dr. Dante Reis Júnior

Departamento de Geografia, Universidade de Brasília

(Examinador interno)

Prof. Dr. Carlos Hiroo Saito

Departamento de Ecologia, Universidade de Brasília

(Examinador externo) 
FICHA CATALOGRAFICA

NASCIMENTO, RAFAELA ARAÚJO DO

A paisagem da bacia hidrográfica do Rio Corrente-PI e suas modificações pela lente das crianças do ensino fundamental. 2016, 85 p. (GEA/IH/UnB, Mestre, Geografia Análise de Sistemas Naturais, 2016).

Dissertação de Mestrado - Universidade de Brasília. Instituto de Ciências Humanas. Departamento de Geografia.

1. PRÁTICAS E TÉCNICAS DE ENSINO

2. PAISAGEM E ICONOGRAFIA NA GEOGRAFIA

3. PROCEDIMENTOS METODOLÓGICOS

4. RESULTADOS E DISCUSSÕES

É concedida à Universidade de Brasília permissão para reproduzir cópias desta Dissertação e emprestar ou vender tais cópias somente para propósitos acadêmicos e científicos. A autora reserva outros direitos de publicação e nenhuma parte desta dissertação de mestrado pode ser reproduzida sem a autorização por escrito da autora. 
Aos meus pais,

Edilene e Robson, e ao meu sobrinho, Guilherme. 


\section{AGRADECIMENTOS}

Em primeiro lugar agradeço ao meu sobrinho Guilherme que, apesar de sua pouca idade, me motivou mais do que tudo a fazer esta pesquisa. Aos meus pais, Edilene e Robson, e aos irmãos, Robson Filho, Rafael e Elias, por me ajudarem em tantos momentos adversos.

A Ana Maria Brito e a Delcy Nogueira, pela colaboração e disponibilidade quanto à autorização para a aplicação deste estudo na Unidade Escolar Desembargador João Pacheco Cavalcante e aos alunos desta instituição por participarem deste trabalho.

A Prefeitura de Corrente-PI, em especial a Secretária de Meio Ambiente e a Eduardo Rocha pelo fornecimento de algumas fotografias. Agradeço também aos cidadãos correntinos que forneceram alguns dados e fotografias para esta pesquisa.

Ao amigo Marcelo Scarabuci, pelas consultas nas quais sempre se mostrou disposto a me ajudar. Aos amigos Lucas Lira, Heraldo Botelho, Genebaldo Rios e Wesley Gomes pela ajuda prestada ao longo desta pesquisa.

Aos bolsistas do LAGIM, Thiago Almeida, Igor Gomes e Andrey Lago pela ajuda em alguns momentos desta pesquisa.

Ao professor Dr. Valdir Steinke, por me auxiliar nesta pesquisa e pela orientação neste trabalho.

Aos professores Dr. Carlos Saito e Dr. Dante Júnior pelas contribuições nas bancas de qualificação e defesa de dissertação.

Agradeço a Universidade de Brasília, Instituto de Ciências Humanas e ao Departamento de Geografia por me permitirem realizar esta pesquisa. 
“[...] O que vai ficar na fotografia São os laços invisíveis que havia As cores, figuras, motivos O sol passando sobre os amigos Histórias, bebidas, sorrisos $[\ldots] "$ (Fotografia, Composição: Leoni e Léo Jaime) 


\section{RESUMO}

A presente pesquisa apresenta algumas definições de paisagem e suas principais mudanças ao longo do tempo. Analisa a mudança na paisagem da bacia hidrográfica do rio Corrente, em Corrente-PI, focando na mudança causada pela ação antrópica, por meio da iconografia produzida por crianças do $7^{\circ}$ ano do Ensino Fundamental. Apresenta abordagens pedagógicas e educacionais sobre como é abordada a paisagem no ensino fundamental.

Palavras-chave: Paisagem. Fotografias. Bacia hidrográfica. Ensino. 


\begin{abstract}
This research presents some landscape settings and main changes over time. Analyzes in the changing landscape of the river hydrographic basin Corrente, in Corrente-PI, focusing on change caused by human action, through the iconography produced by children of the 7th year of elementary school. Presents pedagogical and educational approaches on how the landscape is covered in elementary school.
\end{abstract}

Keywords: Landscape. Photographs. Hydrographic basin. Education. 


\section{LISTA DE FIGURAS}

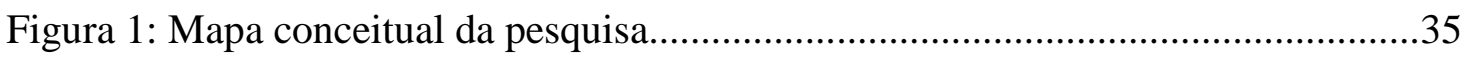

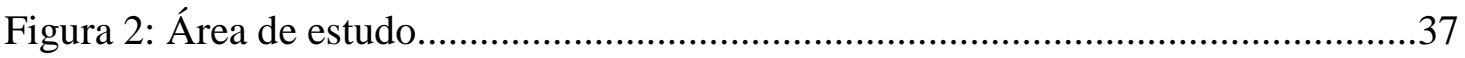

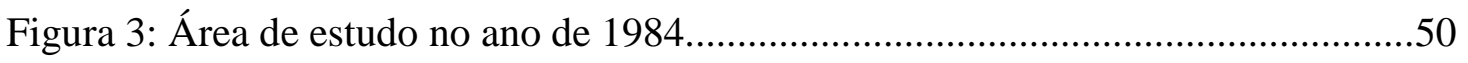

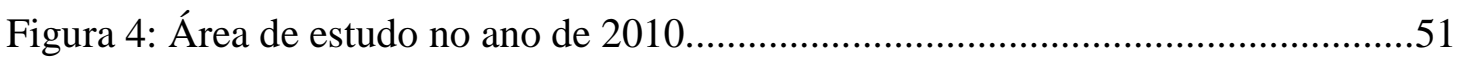

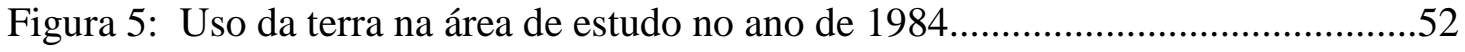

Figura 6: Uso da terra na área de estudo no ano de 2010 ...........................................53

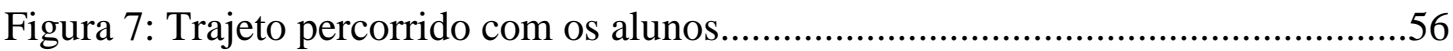

Figura 8: Fotografia tirada na parada 1 durante o percurso de ida................................57

Figura 9: Fotografia tirada na parada 1 durante o percurso de volta.............................58

Figura 10: Fotografia tirada na parada 2 durante o percurso de ida.............................59

Figura 11: Fotografia tirada na parada 2 durante o percurso de ida..............................60

Figura 12: Fotografia tirada na parada 3 durante o percurso de ida.............................61

Figura 13: Fotografia tirada na parada 3 durante o percurso de volta..........................62

Figura 14: Fotografia tirada na parada 4 durante o percurso de ida.............................63

Figura 15: Fotografia tirada na parada 4 durante o percurso de volta...........................64

Figura 16: Fotografia da área conhecida como "barragem", aproximadamente, em

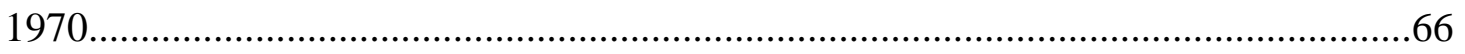

Figura 17: Fotografia da área conhecida como "barragem", em 2014.........................66

Figura 18: Média das notas dadas pelos alunos no protocolo, para cada parada...........68

Figura 19: Elementos naturais $\mathrm{X}$ elementos antropizados fotografados na primeira saída

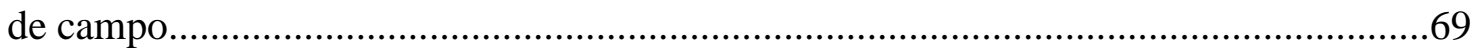

Figura 20: Alunos após a exposição dos trabalhos................................................... 70 
Sumário

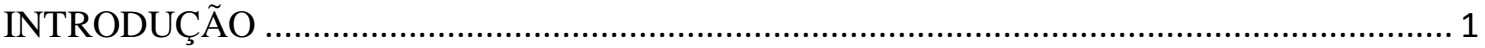

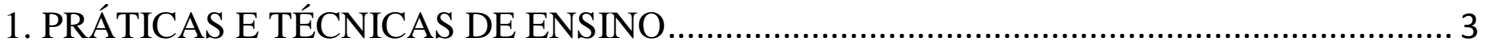

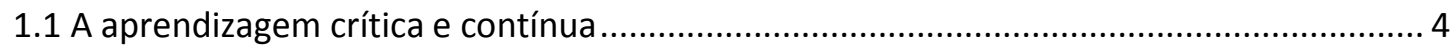

1.2 A paisagem no ensino segundo os Parâmetros Curriculares Nacionais - PCN.................... 9

1.30 ensino e as interações socioculturais na paisagem ..................................................... 15

2. PAISAGEM E ICONOGRAFIA NA GEOGRAFIA ........................................................ 18

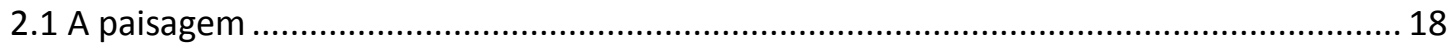

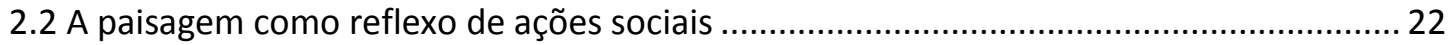

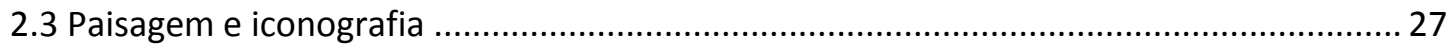

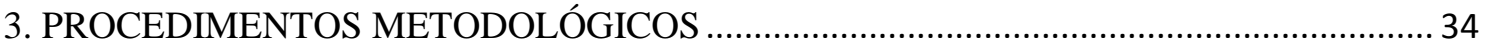

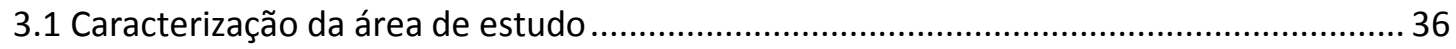

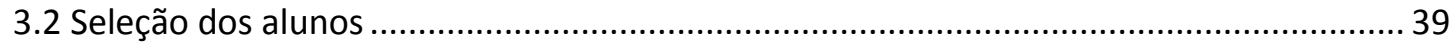

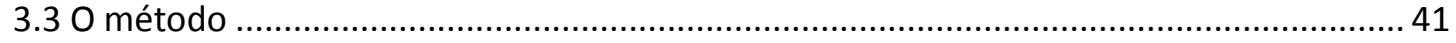

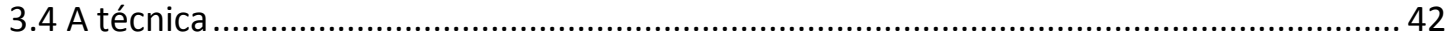

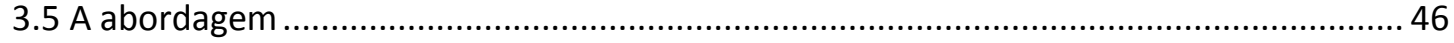

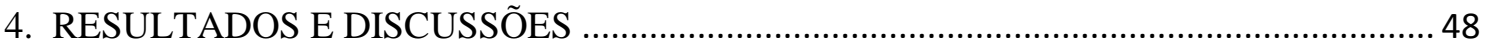

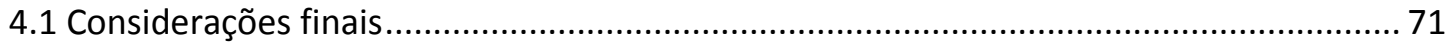

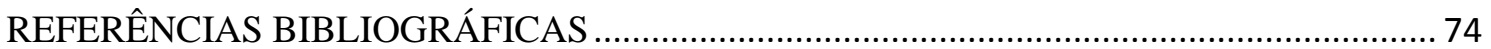

APÊNDICE A - PROTOCOLO DE AVALIAÇÃO ............................................................... 82

APÊNDICE B - PLANO DE AULA DA PRIMEIRA SAÍDA DE CAMPO .............................. 83

APÊNDICE C - PLANO DE AULA DA SEGUNDA SAÍDA DE CAMPO ……...................... 84

APÊNDICE D - AUTORIZAÇÃO DE USO DE IMAGEM, SOM DE VOZ, NOME E

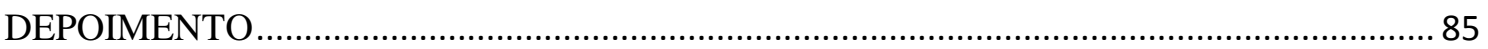




\section{INTRODUÇÃO}

A história da vivência social sempre foi registrada ao longo do tempo, seja através de pinturas, relatos do cotidiano, fotografias ou vídeos. Tais registros estabelecem uma relação de identidade com acontecimentos e com o território, fazendo com que determinada imagem seja associada a um lugar e consequentemente a uma lembrança.

O estudo da paisagem permite analisar as modificações sociais que estão ocorrendo na região, pois a partir do momento em que uma sociedade muda o seu meio de produção e o convívio com o meio, modifica também a paisagem com a qual tem contato para que lhe seja proporcionado um maior desenvolvimento e qualidade de vida. Tal constatação pode ser observada na Inglaterra do século XIX, em que juntamente com a Revolução Industrial houve uma mudança drástica na paisagem que era, majoritariamente, natural e passou a ser urbana e rural antropizada.

As mudanças na paisagem devem ser observadas e contextualizadas para que se tenha uma análise da realidade, pois segundo Souza e Souza (2013, p.109), “[...] Concebemos que a contemplação da imagem capturada de determinado momento (situação, objeto, pessoas etc), é única, pois tal momento não se repetirá mais na realidade, foi capturado e será representado na fotografia, dando-nos a oportunidade de (re)criar pensamentos, emoções, lembranças e reflexões".

A presente pesquisa envolve abordagens pedagógicas e educacionais sobre como é abordada a paisagem no ensino fundamental, assim como a percepção de uma determinada amostra de alunos acerca das modificações na paisagem da bacia hidrográfica do rio Corrente, em Corrente-PI. Tais abordagens envolvem conceitos de paisagem cultural e física, assim como os resultados da interação homem-meio na paisagem. Caetano e Bezzi (2011, p.454) afirmam que "a paisagem, como objeto da interpretação da Geografia, permite a leitura da cultura e a história de um povo através da manifestação dos valores, crenças e demais atributos que os identificam". Considerando as relações estabelecidas entre o homem/meio ambiente e as alterações ambientais causadas por modificações no uso da terra, esta pesquisa discute alguns conceitos sobre paisagem, focando na mudança de paisagem por ação antrópica.

O Serviço Geológico do Brasil - CPRM (2004) afirma que em algumas regiões do nordeste brasileiro há escassez de água e que tal situação de escassez poderia ser 
contornada se houvesse uma melhoria no uso e emprego adequado dos recursos hídricos presentes na região.

A presente pesquisa propõe o estudo da iconografia produzida por crianças do Ensino Fundamental para caracterização da paisagem na região. A visão construída com as crianças visa estabelecer uma relação de identidade com a paisagem local e experiência social, juntamente com os saberes propostos para a educação brasileira na fase em que estas se encontram. A geoiconografia será utilizada na caracterização da percepção social frente às mudanças na paisagem local, neste trabalho o tema central abordado foi o assoreamento, apenas pelos indicadores visuais, que podem ser percebidos pelos alunos do ensino fundamental.

O assoreamento de rios, é um excelente indicador das transformações na paisagem, pois apresenta como a sociedade interage com o meio e como estas transformações podem afetar consideravelmente o cotidiano.

Desta forma, chega-se ao seguinte questionamento: As crianças percebem o assoreamento do rio Corrente, em Corrente-PI, como consequências das ações antrópicas?

Assim, esta pesquisa tem como objetivos fazer com que os alunos conheçam e entendam mais sobre as modificações que ocorrem na paisagem localizada no rio que corta a cidade, fazendo com que haja uma identidade territorial e, consequentemente, uma maior conscientização de preservação ambiental nestas crianças. Desta forma, as crianças que participaram deste estudo podem refletir sobre suas ações enquanto cidadãs no ambiente em que vivem. Partindo desta questão, os alunos participam de atividade práticas de campo e em sala de aula para mostrar a importância da preservação ambiental e também as consequências de suas ações frente às modificações ambientais que estão acontecendo na região. 


\section{PRÁTICAS E TÉCNICAS DE ENSINO}

Os professores, quanto à prática docente, devem ter em mente que os conteúdos discutidos em salas de aula não são conteúdos isolados e/ou a-históricos e, justamente por isto, devem ser abordados de forma interdisciplinar, pois os fatos e conhecimentos estão sempre se transformando e, em alguns casos, se alterando. A interdisciplinaridade teria como ponto de partida, não apenas a discussão teórica sobre os fatos, mas também a prática, dando uma abordagem teórico-prático da realidade.

O desafio educacional, no que tange a prática de ensino, proporciona tanto ao educador quanto ao educando um processo de discussão aprofundada sobre temas do cotidiano, estabelecer relações de causa-efeito com diversos acontecimentos ocorridos na sociedade e encarar os acontecimentos "num plano de totalidade não como algo petrificado, a compreensão resultante tende a tornar-se crescentemente crítica, por isto, cada vez mais desalinhada" (FREIRE, 2011, p.98).

[...] Freire nos ensinou que a educação nunca é neutra, que tem uma intencionalidade que envolve práticas, valores, utopias que reproduzem, legitimam, questionam ou transformam as relações de poder prevalecentes na sociedade. Uma dimensão que se sustenta em homens e mulheres que "estão sendo", inacabados, urgidos de diálogo para construir-se como pessoas e como sujeitos sociais de mudança, que se organizam de diversas formas não só partidárias, mas também em suas organizações de base e de movimentos sociais, construindo poder subjetivo, popular e democrático (ROSSEL, 2012, p.457).

A prática continuada de desconstrução de objetos e pensamentos com educandos faz com que estes sejam desafiados a ver o mundo em que vivem de forma mais ampla, relacionando acontecimentos diversos no meio social, o que proporciona o estabelecimento de conexões com questões sociais, ambientais e culturais. Esta pesquisa tem como um dos princípios da educação dialógico-problematizadora proposta e defendida por Freire (2008), pois esta possibilita aos educandos e educadores uma transformação não apenas no conhecimento discutido em sala de aula, mas também na sociedade, pois gera uma comunicação e discussão de temas fundamentais para a sociedade, utilizando temas primários para o estabelecimento de diálogos e de desenvolvimentos políticos nos alunos. 


\subsection{A aprendizagem crítica e contínua}

A aprendizagem crítica ocorre quando o professor não apenas ensina os conteúdos sugeridos para uma determinada classe em sala de aula, mas sobretudo quando este os relaciona com fatos do cotidiano dos alunos, fazendo com que os alunos estabeleçam um olhar crítico de suas realidades. Partindo de tal premissa, o pensamento freireano defende tal ideia e esta servirá como ponto de partida na análise dos métodos de ensino abordados nesta pesquisa.

A ótica freireana apresenta alguns pontos pertinentes a esta pesquisa, como por exemplo: "o diálogo, a construção coletiva e a intencionalidade política" (RODRIGUES; MACHADO, 2012, p.488). Neste sentido, as contribuições freireanas vão além de análises momentâneas acerca do ensino, tornando as práticas pedagógicas algo constante e permanente na vida escolar e social dos alunos. “[...] Freire reivindicou a utopia de uma educação para a vida, para o amor, a justiça e a solidariedade entre os homens" (ROSSEL, 2012, p.457).

O conhecimento desenvolvido em pesquisas científicas deve ser discutido em sociedade para que todos opinem sobre as modificações que irão ocorrer em seu meio social/ambiental. A ação individual não necessariamente caracteriza uma ação benéfica ao meio, pois é necessário estabelecer um diálogo com os mais diversos setores e estratos sociais. Os professores têm papel de mediador de informações e diálogo no momento em que se estabelece o contato entre o conhecimento científico e o social. Este tipo de articulação

[...] proporcionou a articulação entre o conhecimento e a ação; o primeiro orientando a ação e sendo, por sua vez, redimensionado com base nos resultados dessa mesma ação. Esse é um aspecto fundamental do processo de construção do conhecimento, que se encontra presente no conceito de práxisação- reflexão como constituintes da compreensão transformadora da realidade (LUCATTO; TALAMONI, 2007, p.396).

O educador, ao longo de sua caminhada social e educacional, deve fazer com que seus educandos sejam cada vez mais críticos e conscientes de suas ações. "[...] Se nos interessa analisar o compromisso profissional com a sociedade, teremos que reconhecer que ele, antes de ser profissional, é homem. Deve ser comprometido por si mesmo" (FREIRE, 2008, p.19). Desta forma, o educador reforça a capacidade crítica do educando, o que, consequentemente, faz com que seja desenvolvida cada vez mais a curiosidade dos educandos. Contudo, não se trata apenas da "repetição mecânica do 
gesto, este ou aquele, mas a compreensão do valor dos sentidos, das emoções, do medo que, ao ser 'educado', vai gerando a coragem" (FREIRE, 1996, p.45). Neste momento, torna-se interessante abordar alguns temas de forma mais crítica e rigorosa, para fazer com que os educandos consigam estabelecer relações entre o saber escolar e o senso comum.

O objeto a ser analisado, deve incitar no educando a curiosidade sobre os sistemas estabelecidos num fato, de forma a gerar a compreensão do objeto e discutir se tal análise foi feita de forma correta ao invés de recebê-la já pronta do professor, pois como defende Freire (1996, p.47) "ensinar não é transferir conhecimento, mas criar as possibilidades para a sua própria produção ou a sua construção”. Com isto, o educando poderá tomar decisões conscientes sobre suas ações e, à medida que adquira um senso cada vez mais ético sobre suas ações, ele insere no seu cotidiano práticas de responsabilidade social, mostrando que a análise crítica ensina a ter compromisso social.

Rossel (2012, p.460) afirma que "Paulo Freire, desde a pedagogia crítica, propôs uma ruptura epistemológica do paradigma egocêntrico e antropocêntrico da cultura ocidental", em que o pensamento proposto interroga as relações de poder que se estabelecem no meio social e reconhece as diferenças e as desigualdades que acontecem neste. Além disto, é proposto a superação das desigualdades sociais como a melhor forma de se atingir a situação social ideal, em que há uma junção da construção utópica com a realidade.

A partir do momento em que o educador reforça a capacidade crítica em seus educandos, estes estabelecem senso crítico e consciente para construir e desconstruir o saber que foi ensinado. Freire (1996, p.26) chama esta fase do ensino de "condições de verdadeira aprendizagem", pois neste ponto, o educando se tornaria também "sujeito do processo". A medida que os homens assumem uma postura crítica sobre os acontecimentos, Freire (2011, p.137) afirma que "tanto mais aprofundam a sua tomada de consciência em torno da realidade e, explicitando sua temática significativa, se apropriam dela". Ao fazer com que o educando tenha consciência crítica acerca de acontecimentos, este se torna cada vez menos neutros aos acontecimentos do mundo.

Contudo, o educador não pode se deixar levar pelo saber do senso comum e tão pouco se direcionar aos educandos de forma autoritária de dono do saber, pois "o diálogo em que se vai desafiando o grupo popular a pensar sua história social como a 
experiência igualmente social de seus membros, vai revelando a necessidade de superar certos saberes que, desnudados, vão mostrando sua 'incompetência' para explicar os fatos" (FREIRE, 1996, p.81).

Delval (2013, p.128) afirma que "la función del profesor es ayudar al niño a que comiece a reflexionar sobre su realidad y proporcionarle los recursos necesarios para que lleve a cabo ese análisis", pois o professor deve levar sempre em consideração a realidade com a qual o aluno tem contato para posteriormente fazer relações com ambientes que os alunos não conhecem ou não possuem muito contato. Neste sentido, Lucatto e Talamoni (2007) afirmam que a questão ambiental, quando estudada por meio de uma pedagogia que tenha a possibilidade de transformar a sociedade, mais humana e com um processo permanente de construção social fazem com que os alunos se tornem cada vez mais engajados socialmente.

Assim como os sujeitos estão em permanente construção, a escola também se faz e refaz frente aos desafios que lhes são impostos. A avaliação emancipadora propõe soluções que atingem o âmago da competência histórica da instituição escolar em termos de construção do conhecimento e realização da cidadania (SANTANA et al, 2013, p.180).

Neste sentido, a cidadania exercida pelos indivíduos de um meio deve ser pautada no coletivo pois esta "é sem dúvida uma questão de direito universal e de princípios republicanos, mas é também em seu acesso e exercício algo datado e situado, não de modo determinista, mas socialmente constituída" (CALLAI; MORAES, 2014, p.7).

O processo de ensino não deve se esgotar nas salas de aula, o educador deve fazer com que seus alunos consigam entender os conceitos aprendidos em sala e os relacionem com acontecimentos de seu dia-a-dia. Saito et al (2012) afirmam que deve haver um processo de codificação-descodificação nos meios e conhecimentos discutidos em sala de aula de forma a estabelecer uma busca cada vez mais constante "por justiça social e o fortalecimento da democracia”. Nesta afirmação reside o fato de que a afetividade e a identificação com questões relacionadas ao território podem fortalecer os laços estabelecidos com o meio, e que as atividades de campo devem ser voltadas para uma integração entre os temas abordados nas salas de aula, como uma forma de fixação do conteúdo discutido, mas também mostrar as relações estabelecidas entre o homem e o meio. Desta forma, “a produção simbólica destinada a compreender e balizar o mundo 
provém de um sujeito ativo e criativo, tem um caráter cognitivo e autônomo e configura a construção social da realidade" (BARROS, 2013, p.173).

O código, segundo Saito (1999), seria um instrumento relacionado a temas vividos no cotidiano nos alunos e ocorreria um processo de investigação da realidade, em que a descodificação se daria de forma a proporcionar aos alunos estabelecerem relações com mundo. "O processo de descodificação leva os indivíduos a interpretar a realidade codificada, revelando o que está escondido nas imagens do cotidiano e permitindo a compreensão dos conflitos socioambientais apoiados por conhecimentos científicos e tecnológicos" (SAITO et al, 2012, p.492). Paralelamente a este pensamento, nota-se em Freire (1996) ideias que constroem cada vez mais a continuidade do pensamento crítico, como pode ser observado abaixo:

Por isso é que, na formação permanente dos professores, o momento fundamental é o da reflexão crítica sobre a prática. É pensando criticamente a prática de hoje ou de ontem que se pode melhorar a próxima prática. O próprio discurso teórico, necessário à reflexão crítica, tem de ser de tal modo concreto que quase se confunda com a prática (FREIRE, 1996, p.39).

Tais linhas de pensamento, rompem com o pensamento tradicional de que a prática deve ser pré-estabelecida antes de se conhecer os educandos, mostrando que deve sim haver uma formação continuada e permanente dos educadores para que se tenham novas técnicas e métodos de discursão, seja sobre temas atuais ou não.

Neste sentido, o "ensinar" não se acaba no simples desconstruir do objeto e/ou do conhecimento, mas continua até o estabelecimento do aprender criticamente. Ao analisar a realidade, os indivíduos geram uma percepção que "condiciona também a forma de enfrentá-la, suas perspectivas, suas aspirações, suas expectativas. Condiciona também os vários níveis de percepção que, por sua vez, explicam as formas de ação dos indivíduos" (FREIRE, 2008, p.58).

Unir aspectos de ensino e afetivos faz com que haja uma aprendizagem mais intensa, fazendo com que se estabeleça uma identidade territorial entre o aluno e o meio ambiente com o qual ele tem contato, levando "a uma aprendizagem mais significativa e mostra a natureza do conhecimento científico como fruto do raciocínio lógico e também dos valores construídos durante a formação escolar" (SENICIATO; CAVASSAN, 2004, p.133). 
Os docentes, em suas práticas de ensino, e a escola como a instituição que tem como um dos elementos de ensino preparar os educandos para a convivência em sociedade, dentre os elementos pré-estabelecidos de ensino, também mostram a seus alunos algumas práticas de cidadania e convivência a serem seguidas na sociedade. Desta forma, docentes e discentes devem dialogar sobre as práticas a serem ensinadas nas salas de aula, a

[...] Forma como docentes e discentes consideram a questão de que a escola deve ensinar cidadania se traduz por um conjunto de fazeres que precisariam ser cumpridos, de ações que devem ser realizadas no cotidiano. Deste modo, está muito longe de ser possível realizar a reflexão que permita teorizar sobre as práticas, que levem a elaborar e construir os conceitos que são fundamentais para entender o mundo e viver a vida humana (CALLAI; MORAES, 2014, p.13).

Ensinar e aprender, na prática educacional crítica, seguem lado a lado, seja no conhecimento já existente ou no momento em que se constrói o conhecimento ainda não existente. Este ensino e aprendizagem são encarados de forma construtiva na prática da docência e da discência, sendo cada vez mais necessárias nos meios sociais, pois se está passando cada vez mais por mudanças não apenas conceituais, mas metodológicas também.

Constatamos, dessa maneira, que a experiência profissional pautada na crítica e reflexão contínuas sobre as práticas de sala de aula permite ao professor inventar e se apropriar conscientemente de uma série de esquemas práticos e estratégicos de ação, um rico e intenso processo de pedagogização da matéria ensinada que, armazenados, avaliados e retroalimentados, constituem-se em valioso acervo profissional do professor (LOPES; PONTUSCHKA, 2015, p.89).

No que tange às relações do cotidiano, a escola" pode "proporcionar experiências nas quais os alunos possam construir outras representações de ambiente" (MANÉIA; KROHLING, 2012, p. 1541). Freire (1996) sugere que o educador deve discutir com os seus educandos a realidade concreta associada à disciplina que será ensinada, estabelecendo desta forma, uma relação de intimidade entre os saberes estabelecidos pelos Parâmetros Curriculares Nacionais - PCN e a experiência social. "É

\footnotetext{
1 "Por isso mesmo pensar certo coloca ao professor ou, mais amplamente, à escola, o dever de não só respeitar os saberes com que os educandos, sobretudo os das classes populares, chegam a ela saberes socialmente construídos na prática comunitária mas também, como há mais trinta anos venho sugerindo, discutir com os alunos a razão de ser de alguns desses saberes em relação com o ensino dos conteúdos" (FREIRE, 1996, p.30).
} 
preciso por outro lado e, sobretudo, que o educando vá assumindo o papel de sujeito da produção de sua inteligência do mundo e não apenas o de recebedor da que lhe seja transferida pelo professor" (FREIRE, 1996, p.124).

\subsection{A paisagem no ensino segundo os Parâmetros Curriculares Nacionais - PCN}

Durante as práticas de ensino, não se recomenda delimitar uma determinada ótica aos educandos, pois

As pessoas têm a liberdade de dar significados diferentes para as coisas, e no seu cotidiano elas convivem com esses significados. Uma paisagem, seja de uma rua, de um bairro, ou de uma cidade, além de representar uma dimensão concreta e material do mundo, está impregnada de significados que nascem da percepção que se tem dela. No seu cotidiano os alunos convivem de forma imediata com essas representações e significados que são construídos no imaginário social. Quando um aluno muda de rua, de escola, de bairro ou de cidade, ele não sente apenas as diferenças das condições materiais nos novos lugares, mas também as mudanças de símbolos, códigos e significados com os lugares. Em cada imagem ou representação simbólica, os vínculos com a localização e com as outras pessoas estão a todo o momento, consciente ou inconscientemente, orientando as ações humanas (PCN, 1998, p. 23).

Os conceitos acerca da contextualização sociocultural envolvem unidades espaciais geográficas como paisagem, lugar, território, espaço globalizado/mundializado, e devido a isto, se estabelece a prática de ensino em que certos conteúdos tem uma ordem a serem seguidos. A escola, neste sentido, exerce um papel de fundamental importância no que tange a integrar temas diversos no ensino dos alunos, seja de forma transversal e/ou interdisciplinar, pois "o papel da escola ao trabalhar temas transversais é facilitar, fomentar e integrar as ações de modo contextualizado por meio da transversalidade, buscando não fragmentar em blocos rígidos os conhecimentos para que a educação realmente constitua um meio de transformação social" (SANTANA et al, 2013, p.192).

Desta forma, os PCN (1998, p.26) definem que "a Geografia tem por objetivo estudar as relações entre o processo histórico na formação das sociedades humanas e o funcionamento da natureza por meio da leitura do lugar, do território, a partir de sua paisagem". Assim, se espera que os educandos possam ser capazes de 
[...] Conhecer o funcionamento da natureza em suas múltiplas relações, de modo que compreenda o papel das sociedades na construção do território, da paisagem e do lugar; [...]conhecer e saber utilizar procedimentos de pesquisa da Geografia para compreender a paisagem, o território e o lugar, seus processos de construção, identificando suas relações, problemas e contradições (PCN, 1998, p.35).

Tendo como base as normas definidas quanto à prática docente de geografia, os professores, juntamente com as escolas, têm a tarefa de permitir o acesso a certos tipos de conhecimentos e de tal forma que faça com que os diversos perfis de alunos não apenas aprendam, mas também discutam os seus pontos de vista acerca do que está sendo discutido nas salas de aulas e na sociedade.

Ou seja, por outras palavras, retirar o maior benefício do princípio orgânico da multiplicidade. [...] Assim, para que as teorias da cidadania e da democracia tornem consequente a relação entre cidadãos e Estado, substantivando-a e sendo curso às formas de representação e de exercício de poder, bem assim como à articulação entre a modernização da administração e as políticas públicas, torna-se necessário que as teorias do multiculturalismo assumam novo relevo no campo da educação (MAGALHÃES, 2013, p.105).

O ensino nas escolas deve levar em consideração o fato de que "alguns princípios são gerais e básicos e universais e deles não se poderia abrir mão. Outros precisam ser contextualizados e considerados como possibilidade de avançar na superação das diferenças sociais que existem no Brasil” (CALLAI; MORAES, 2014, p.7).

No processo de construção de ensino, a Geografia aborda diversas escalas espaciais em diferentes épocas, inserindo neste meio as questões sociais, culturais e naturais das paisagens. Estas relações fazem com que os alunos possam entender as dinâmicas que ocorrem nos diversos processos que terão contato ao longo da vivência social. Assim, os educandos podem "identificar e relacionar aquilo que na paisagem representa as heranças das sucessivas relações no tempo entre a sociedade e a natureza em sua interação" (PCN, 1998, p.26).

Teoria e prática não são dois polos contrapostos senão complementários. A reflexão é a forma mais simples de fazer a ponte entre teoria e prática. Encontramo-nos com um duplo sentido no conhecimento didático: aquele orientado para a construção da disciplina mediante o crescimento do corpo teórico do conhecimento sobre o ensinoaprendizagem e o encaminhado à mudança ou inovação. Um e outro conhecimento 
exigem a vertente explicativa. Negar o caráter explicativo é negar sua possibilidade como construção científica. Mas a explicação resulta insuficiente (LA TORRE, 2012 p.30).

Quanto à formação dos docentes, estes devem estar em constante atualização de conhecimentos, pois há cada vez mais técnicas de ensino e assuntos a serem discutidos com os alunos. Desta forma, a docência estabelece uma relação de não apenas transmitir um tipo de conhecimento, mas também discutir a formação social dos alunos em que "a formação dos profissionais para uma ação docente de qualidade é hoje uma exigência de justiça social, destacando-se a responsabilidade das agências formadoras, das políticas de formação docente e, em especial, da pós-graduação" (BEZERRA, 2013, p.17-18).

O professor de geografia não pode se esquecer que o conhecimento vai além das salas de aula, além dos conteúdos programáticos de um livro didático ou da simples leitura de uma paisagem, "una educación democrática tiene que estar relacionada necessariamente con unos contenidos educativos determinados, pero también, y sobre todo, con uma forma de funcionamiento de las instituciones escolares, porque la democracia no es un conjunto de conocimientos sino que es ante todo una práctica" (DELVAL, 2013, p.120). Ele deve, juntamente com seus educandos, estudar a paisagem como um caminho para perceber as interações antrópicas e ambientais que ocorrem na construção dos espaços. Cavalcanti (2005), parte da premissa de que:

[...] Na relação cognitiva de crianças, jovens e adultos com o mundo, o raciocínio espacial é necessário, pois as práticas sociais cotidianas têm uma dimensão espacial, o que confere importância ao ensino de geografia na escola; os alunos que estudam essa disciplina já possuem conhecimentos geográficos oriundos de sua relação direta e cotidiana com o espaço vivido; o desenvolvimento de um raciocínio espacial conceitual pelos alunos depende, embora não exclusivamente, de uma relação intersubjetiva no contexto escolar e de uma mediação semiótica (CAVALCANTI, 2005, p.198).

Tratar questões ambientais como ocasionadas por acontecimentos sociais, culturais e econômicas se tornou cada vez mais constantes, pois ao se analisar um mesmo acontecimento por diversas óticas é possível estabelecer relações de causa e efeito.

É preciso que haja concepções teórico metodológicas capazes de permitir o reconhecimento do saber do outro, a capacidade de ler o mundo da vida e reconhecer a sua dinamicidade, superando o que está posto como verdade absoluta. É preciso 
trabalhar com a possibilidade de encontrar formas de compreender o mundo, produzindo um conhecimento que é legítimo (CALLAI, 2005, p.231).

Assim, analisar o meio social em que o educando está inserido se torna cada vez mais relevantes nos estudos da paisagem. Oliveira e Kunz (2014, p.142) sugerem uma "abordagem mais ampla de trabalho, cuja cidadania, autonomia e o desenvolvimento de habilidades e competências acabam sendo centrais". Em consonância com estes autores, Cavalcanti (2005, p.196) afirma que "o desenvolvimento do pensamento conceitual, entendendo que ele permite uma mudança na relação cognitiva do homem com o mundo, é função da escola e contribui para a consciência reflexiva do aluno". A paisagem local se torna cada vez mais importante para educadores e educandos, pois ela expressa as mudanças de pensamento e práticas de vivência que ocorrem ao longo do tempo. Neste sentido, ao fazer com que os alunos realizem atividades de campo com cunho social, os educadores fazem com que os alunos desenvolvam formas de analisar os acontecimentos como uma cadeia, mostrando como um acontecimento pode influenciar em outro, pois:

O ensino transdisciplinar é um ato intencional de construção de signos, significados, de desenvolvimento afetivo, cognitivo, perceptivo, relacional, de ampliação da consciência e de comprometimento do sujeito com a metamorfose planetária, social e antropológica. Nesse processo a tarefa da didática transdisciplinar é construir ambientes, metodologias, processos inovadores que ajudem os acadêmicos na autoecoorganização dos conhecimentos complexos, transdisciplinares e dialógicos construídos a partir da reforma do pensamento e da reforma da educação (SUANNO, 2012, p.221).

O professor exerce um papel de vital relevância no processo de aprendizagem, principalmente no que tange a transformações sociais e consequentemente no meio ambiente, "a qualificação do professor consiste em conhecer o mundo e ser capaz de instruir os outros acerca deste. Porém, sua autoridade assenta-se na responsabilidade que ele assume por este mundo" (SENICIATO; CAVASSAN, 2004, p.138). Mahdjoubi e Akplotsyi (2012) realizaram pesquisas relacionadas a formas de ensino, contudo eles não consideraram plenamente as questões individuais de cada aluno em seu estudo. Ao discutir temas que agregam o conhecimento escolar com o social, o professor faz com que os alunos criem uma relação de identidade com o meio, mostrando como as ações praticadas pelos alunos podem influenciar na sociedade e o quando a sociedade pode influenciar as ações dos alunos. 
Os questionamentos discutidos por meio dos Parâmetros Curriculares Nacionais fazem com que o professor "através de seu autoconhecimento, em um caminho próprio de conhecimentos, torna-se possível também compreender o outro, ajudar o educando a compor uma realidade em seu entorno, percebendo e entendendo a necessidade de mudanças no meio social em que se está inserido " (SANTOS; ANTUNES, 2013, p.303).

É definido para o terceiro ciclo, no estudo da Geografia, que o professor tenha como foco as mudanças ambientais geradas por questões sociais, pois "a paisagem local e o espaço vivido são as referências para o professor organizar seu trabalho e, a partir daí, introduzir os alunos nos espaços mundializados" (PCN, 1998, p.51).

De acordo com o segundo grupo de competências, os educandos devem conseguir "reconhecer os fenômenos espaciais a partir da seleção, comparação e interpretação, identificando as singularidades ou generalidades de cada lugar, paisagem e território" (PCN, 2000, p.35). Neste momento, é interessante que os educandos "compreendam alguns aspectos da história do povoamento e a expressão das desigualdades regionais, pelas marcas deixadas na paisagem natural e cultural" (PCN, 1998, p.111). Callai (2005, p.231) defende que “a clareza teórico-metodológica é fundamental para que o professor possa contextualizar os seus saberes, os dos seus alunos, e os de todo o mundo à sua volta”.

Portanto, no Ensino Fundamental, a Geografia tem como foco fazer com que o aluno seja capaz de entender os conceitos de paisagem, espaço, natureza, Estado e sociedade, para que posteriormente, possam entender como se estabelece as interações entre estes. Contudo, "o tipo de compreensão dos conteúdos implicado na tarefa de ensinar geografia ultrapassa as preocupações mais imediatas dessa disciplina e solicita, não raramente, conhecimentos mais diretamente relacionados a outras áreas do currículo escolar" (LOPES; PONTUSCHKA, 2015, p.82)

A paisagem, segundo PCN (2006, p.56), é uma "unidade visível do arranjo espacial, alcançado por nossa visão" que possui elementos gerados por ações antrópicas gerados sobretudo por questões econômicas e culturais. É na paisagem, natural ou não, que ocorrem as interações sociais e, devido sobretudo a esta relação social estabelecida com o meio, pode-se analisar a paisagem de maneira formal ou não.

Nesse sentido, a análise da paisagem deve focar as dinâmicas de suas transformações e não simplesmente a descrição e o estudo de um mundo 
aparentemente estático. Isso requer a compreensão da dinâmica entre os processos sociais, físicos e biológicos inseridos em contextos particulares ou gerais. A preocupação básica é abranger os modos de produzir de existir e de perceber os diferentes lugares e territórios como os fenômenos que constituem essas paisagens e interagem com a vida que os anima. Para tanto é preciso observar, buscar explicações para aquilo que, em determinado momento, permaneceu ou foi transformado, isto é, os elementos do passado e do presente que neles convivem (PCN, 1998, p.27).

Os PCN (1998, p.20) utilizam o conceito de paisagem definido por La Blache, em que "os conceitos de lugar, paisagem e região, como territorialidade, se sobrepunham. A ligação dos homens com os lugares ao longo da História produzia um instrumental técnico e cultural que acabava dando a esses lugares a sua identidade, criando padrões de comportamento herdados e transmitidos a outras gerações”.

Tal visão é caracterizada pela constante interação homem-meio e pela presença da paisagem histórica/natural e foi posteriormente foi chamada de gênero de vida. Desta forma, a definição de paisagem dada por La Blache serviu para compreender a diversidade do mundo". Tais pensamentos demonstram que a percepção, gerada através das memórias e interações de indivíduos se torna elemento importante para o geógrafo e seus estudos.

O tempo tem papel fundamental na análise da paisagem, pois com o passar deste, ocorrem interações sociais que farão com que o ambiente seja modificado ou conservado. "O homem se identifica com sua própria ação: objetiva o tempo, temporaliza-se, faz-se homem-história" (FREIRE, 2008, p.30-31). O desenvolvimento social gera modificações no ambiente físico, ocasionados principalmente por questões político sociais, culturais e econômicos.

Tais transformações fazem com que seja estabelecida uma relação de pertencimento a um local, gerando uma identidade social, que cada vez mais se torna relacionada a cultura local, e também fazer com que os alunos tenham cada vez mais "capacidad para analizar racionalmente las situaciones sociales, compararlas de forma critica y escoger entre ellas las más favorables para el bienestar no sólo próprio sino de todos. Por ello, um componente essencial de la vida democrática es la capacidad de decisión autónoma de los ciudadanos” (DELVAL, 2013, p.119). 


\title{
1.30 ensino e as interações socioculturais na paisagem
}

Os alunos, ao longo de práticas educacionais e sociais, entendem o desenvolvimento da sociedade e como se dá o processo de modificação na paisagem, assim como as relações entre esta e questões políticos, culturais e econômicas. Contudo, em alguns casos, o homem não age apenas numa forma de apropriação e modificações impensadas no meio ambiente, ele pode construir o ambiente pensando no social e adaptando o meio a unidades especificas da sociedade e da paisagem, dando uma dimensão naturalizada a uma região.

\begin{abstract}
Assim, como não há homem sem mundo, nem mundo sem homem, não pode haver reflexão e ação fora da realidade homem-realidade. Esta reflexão homem-realidade, homem-mundo, ao contrário do contato animal com o mundo, como já afirmamos, implica a transformação do mundo, cujo produto, por sua vez, condiciona ambas, ação e reflexão. É portanto, através de sua experiência nestas relações que o homem desenvolve sua ação-reflexão, como também pode tê-las atrofiadas. Conforme se estabeleçam estas relações, o homem pode ou não ter condições objetivas para o pleno exercício da maneira humana de existir (FREIRE, 2008, p.17-18).
\end{abstract}

As práticas docentes devem utilizar cada vez mais recursos que estimulem os alunos a estabelecerem relações entre as ações antrópicas e a paisagem, pois assim eles conseguirão entender os processos que ocorrem no meio ambiente e terem uma percepção cada vez mais crítica sobre suas ações e estabelecerem relações construtivas de pertencimento com o meio.

Apesar de o professor ensinar igualmente os alunos de uma turma, cada aluno terá uma aprendizagem diferente, de acordo com as experiências e vivências de cada um, "por isso, os saberes constituídos nas vivências interpessoais e nas práticas educativas são fundamentais nas ações dos docentes, ao enfrentar situações-problemas que porventura surjam" (SANTOS; ANTUNES, 2013, p.302). Neste sentido, Mahdjoubi e Akplotsyi (2012) defendem a ideia de que o professor deve perceber que os alunos têm diferentes conhecimentos e métodos para descodificar uma informação e posteriormente a utilizar, que pode fazer com que um aluno tenha um processo de aprendizagem mais rápido que o outro aluno.

É cada vez maior as modificações feitas na paisagem, seja pela demanda de recursos naturais seja pelas modificações no consumo da população, assim, as práticas educacionais exercem uma função de integrar a cidadania com a aprendizagem em que, 
a educação e a participação sociocultural "tem estado associada à cidadania e à inclusão, que são as virtualidades fundamentais do regime democrático, como regime orientado para o desenvolvimento econômico, cultural, social e individual" (MAGALHÃES, 2013, p.103). O ensino, voltado para questões ambientais, deve estar voltado para a promoção de técnicas que melhorem o meio ambiente, seja preservando-o ou modificando-o de forma consciente.

Nesse sentido e sem que seja aberto aqui o debate cultural, cabe reiterar que a escola se institui e desenvolveu dando substância e alento ao modelo sociocultural e às formas de viver urbanas. Não obstante, a reiteração do discurso inclusivo do rural, à aculturação escolar, deu sequência e legitimou a hegemonia do modelo urbano. Estão assim em confronto distintas dimensões de uma diversidade multicultural que a uniformidade do currículo escolar não permitiu proteger e menos ainda reconhecer e promover. Com efeito, reitere-se que o reforço das políticas públicas nem sempre tem impedido que a crise escolar seja extensiva à relação escola-sociedade (MAGALHÃES, 2013, p.109).

Segundo Cavalcanti (2005, p.198), “o aluno é o sujeito ativo de seu processo de formação e de desenvolvimento intelectual, afetivo e social; o professor tem o papel de mediador do processo de formação do aluno".

As questões ambientais estão cada vez mais inseridas no ensino geográfico, pois há cada vez mais a necessidade de educadores discutirem princípios e valores relacionados ao meio ambiente com seus educandos. Os professores devem ter em conta que "o papel da educação se forma em meio a conflitos, dogmas, ideologias e dúvidas, geradores de angústia. O indivíduo se forma na prática, através de atividades que promovem a transformação social" (MANÉIA; KROHLING, 2012, p.1543). Segundo os PCN (1997, p.44),

Espera-se que o aluno estabeleça relações entre o ambiente construído, nas diferentes formas de produção humana, e as modificações que isso impõe à paisagem natural ou anteriormente construída, compreendendo a relação de complementaridade e interdependência entre os diversos ambientes construídos, e entre estes e as condições naturais em que ocorreram (por exemplo, se a escolha da localização relativa para as casas e para as fábricas foi conveniente; se para uma nova construção haverá perda de um patrimônio natural, cultural ou paisagístico; se a agricultura está sendo feita da forma mais adequada àquele solo, evitando erosão; se o produto consumido na cidade vem da própria região ou de muito longe, por que isso se dá, qual a vantagem ou desvantagem, etc.) (PCN,1997, p.44). 
Assim, partindo desta sugestão, o estudo do meio ambiente e social com a utilização de imagens que mostrem locais que estes alunos se identifiquem em seu convívio social, facilita a didática utilizada na análise das modificações na paisagem. Com esta técnica, os alunos poderão construir e descontruir a percepção que possuem sobre o seu objeto de forma mais ampla e com suas próprias experiências e vivencias. Neste momento, os educandos poderão ler a paisagem de forma a fazerem comparações entre as paisagens de diversos locais e também a observar com maior clareza as relações entre a sociedade e a natureza. 


\section{PAISAGEM E ICONOGRAFIA NA GEOGRAFIA}

A paisagem, e consequentemente as análises feitas nela, mostram as diferentes formas e meios em que ocorrem as dinâmicas sociais e ambientais no meio. Estas modificações podem destacar um fator com mais ênfase, em detrimento de outros, como por exemplo a construção de prédios, a canalização de rios, e a organização de certos espaços. A paisagem nos mostra elementos do passado (herança) e do presente (vivido) que convivem cotidianamente em um mesmo espaço, seja de forma a preservar um aspecto natural, ou uma memória, ou paisagens culturais/antropizadas.

\subsection{A paisagem}

A análise da paisagem, acompanhou o processo de evolução científica e epistemológica, portanto passou por mudanças conceituais e metodológicas ao longo do tempo. Desta forma, não há consenso em torno de uma definição e uma metodologia única a serem seguidas, pois a paisagem torna-se o resultado dos acontecimentos históricos. Ao longo dos anos, os conceitos abordados pelos geógrafos passaram por modificações e adaptações, como por exemplo:

A geografia tradicional em suas diversas versões privilegiou os conceitos de paisagem e região, em torno deles estabelecendo-se a discussão sobre o objeto da geografia e sua identidade no âmbito das demais ciências. Assim, os debates incluíam os conceitos de paisagem cultural, gênero de vida e diferenciação de áreas. Envolviam geógrafos vinculados ao positivismo e ao historicismo, conforme aponta CAPEL (1982) ou, em outros termos, aqueles geógrafos deterministas, possibilistas, culturais e regionais. A abordagem espacial, associada à localização das atividades dos homens e aos fluxos, era muito secundária entre geógrafos como, entre outros, aponta CORRÊA (1986a) (CORRÊA, 1995, p.17).

Os geógrafos analisam a paisagem, dividindo majoritariamente, em paisagem natural e paisagem humanizada, fator este que gera discussões acerca da referência conceitual e da metodologia que deve ser utilizada em suas pesquisas/experimentos. A paisagem sempre esteve presente na ciência geográfica, e

É possível perceber a existência conceitual de várias paisagens, em forma de região, território, lugar, etc., se fazendo presente na geografia física, quanto na geografia cultural [...]. Diferentes legados e contribuições fundamentaram a concepção de paisagem, colocando-a como categoria de análise geográfica (BRITTO; FERREIRA, 2011, p.2). 
Os estudos envolvendo modificações na paisagem proporcionam uma análise acerca das interações físicas e sociais que ocorrem nela, além de fazer com que o pesquisador possa tomar mais de uma característica a ser analisada na sua dinâmica. A paisagem passou por diversas conceituações ao longo de anos e de diferentes territórios:

A geografia alemã, por exemplo, introduziu o conceito da paisagem como categoria científica e a compreendeu até os anos 1940 como um conjunto de fatores naturais e humanos (Otto Schlüter, Siegfried Passarge e Karl Hettner). Os autores franceses, sob influência de Paul Vidal de la Blache e Jean Rochefort, caracterizaram a paysage (ou o pays) como o relacionamento do homem com o seu espaço físico. A revolução quantitativa, iniciada nos anos 40 nos Estados Unidos, substituiu o termo landscape, que estava, até então, em uso nesse país sob influência da geografia alemã (Carl Sauer), pela idéia da "região" (Richard Hartshorne), sendo esta um conjunto de variáveis abstratas deduzidas da realidade da paisagem e da ação humana. Paralelamente, surgiu na Alemanha e no Leste europeu uma idéia mais holística e sinérgica da Landschaft, denominada Landschaftskomplex (Paul Schmithüsen), que definiu as unidades da paisagem pelo conjunto dos seus processos ecológicos. Esta idéia se encontra, entre outros, também na Landschaftsökologie (ecologia da paisagem), como foi proposta por Carl Troll e mais tarde por Hartmut Leser. A Human ecology, de cunho norte-americano, definiu igualmente a paisagem como um sistema ecológico (SCHIER, 2003, p.80).

Os autores franceses, influenciados por La Blache (1941), usam o conceito de paysage (ou o pays) para caracterizar o relacionamento que o homem estabelece com o seu espaço físico. Sauer (1998) e Claval (1999) afirmam em suas obras que é possível notar as diferentes configurações que as paisagens representam, sendo esta gerada da interação homem-meio, resultando na paisagem cultural.

Ritter (1865) sugere que a área de estudo seja delimitada e que suas particularidades sejam analisadas como próprias daquele lugar, para posteriormente serem comparadas a outras regiões. Deste modo, ele se destaca pelo estabelecimento de métodos comparativos entre diferentes regiões e paisagens, estabelecendo uma organização dos elementos ambientais e sociais.

Consequentemente, nota-se que é cada vez mais indispensável à análise dos valores e significados que a sociedade atribui às paisagens com as quais se relacionam. Logo, o conceito de paisagem foi utilizado pelos geógrafos como uma área que pode ser reconhecida e entendida tanto fisicamente quanto culturalmente, podendo ser também 
representada em mapas e imagens, não se restringindo apenas aos elementos alcançados pela vista.

As paisagens acabam sendo diferenciadas não apenas pelo contexto físico, mas também pelas consequências das ações culturais e da elaboração de signos representativos de cada cultura/lugar. Logo, os símbolos impostos, e também relacionados, a uma determinada paisagem "imprimem nesse espaço suas características culturais, ou seja, as paisagens naturais 'evoluem' para paisagens culturais" (CAETANO; BEZZI, 2011, p.455).

A geografia moderna, passou a incluir nos estudos da paisagem os elementos que compõem o espaço, sejam elementos visuais ou resultantes da percepção dos indivíduos, assim como também passou a analisar os eles naturais e os resultantes das ações antrópicas na paisagem. No que tange a relação temporal sofrida pela paisagem, Ferrara (1993, p.163) defende a ideia de que o

Ontem e hoje se espelham mutuamente e permitem à experiência de hoje se identificar no passado, porque lá encontra um padrão, um signo melhor elaborado dela mesma: uma aprendizagem que decorre da experiência sedimentada no repertório, visto, então, como memória da experiência, uma aprendizagem que se equilibra entre a secunridade da ação e a terceiridade alcançada pela inteligibilidade da experiência capaz de gerar um padrão de conduta, um hábito decorrente de ações e reações sedimentadas.

Ao se estudar a paisagem é indissociável o estabelecimento desta com as variações sofridas ao longo do tempo, pois não haverá apenas a paisagem física in natura mas também a paisagem cultural. A paisagem, ao ser compreendida como um emaranhado natural e social, deve ser estudada como "a relação entre a evolução de uma cultura no tempo e a transformação que ela provoca na paisagem natural. Essa paisagem cultural se afirmará desse modo, através das singularidades dos símbolos impressos na mesma, marcando a presença de determinado grupo cultural" (CAETANO; BEZZI, 2011, p.461).

Observar a paisagem e suas mudanças tornou-se importante para pesquisadores que trabalham com o território e questões ambientais, pois isto permite entender o lugar como condição social. Além disto, a percepção constrói e também descontrói a memória individual e coletiva, uma vez que "as lembranças se confundem, podem se confundir com as lembranças de outras pessoas ou ainda não serem efetivamente pessoais, mas passam a ser através de experiências advindas da oralidade, do espaço ou de outro 
veículo, desde que as pessoas envolvidas façam parte dos mesmos grupos sociais" (AZEVEDO, 2013, p.152). Consequentemente,

A evolução das diferentes abordagens filosóficas congrega o conceito de paisagem ora de forma estática, ora dinâmica, ora destacando seu caráter abstrato, ora como produto territorial das ações entre o capital e o trabalho, ora de caráter mais holístico. Atualmente, a paisagem, como um conceito que sintetiza o objeto geográfico, deve abarcar as questões ambientais e estéticas, incluindo o homem e suas ações, diretas ou indiretas, no espaço (BRITTO; FERREIRA, 2011, p.6).

Turri (2011) defende a ideia de que a paisagem se transforma continuamente devido a reterritorialização dos espaços onde o homem interage. Contudo, concomitantemente a modificação de algumas paisagens, a sociedade ainda conserva algumas paisagens, seja por questões de preservação ambiental ou porque fazem parte de momentos importantes em suas vidas.

Não se trata mais da interação do homem com a natureza na paisagem, mas sim de uma forma intelectual na qual diferentes grupos culturais percebem e interpretam a paisagem, construindo os seus marcos e significados nela. Nesta perspectiva, a paisagem é a realização e materialização de ideias dentro de determinados sistemas de significação (SCHIER, 2003, p.81).

A paisagem, portanto, pode ser compreendida como o aspecto visível das transformações sociais no espaço geográfico e a sua observação faz com que seja entendido os acontecimentos físicos e sociais que ocorrem/ocorreram em uma determinada região. Caetano e Bezzi (2011, p.454) dizem ser necessário “integrar o conhecimento físico-biológico ao se desenvolver um estudo atrelado ao processo de transformação da paisagem e a consequente repercussão dessas mudanças para os grupos culturais", pois a paisagem natural não possui as ranhuras causadas pelas ações antrópicas e, para ter uma visão geral das modificações seria necessário abordar a paisagem com as alterações geradas pelos diversos nichos sociais. A pesquisa por meio da percepção ambiental requer alguns cuidados pois,

Para uma pesquisa de percepção ambiental, a contextualização é a primeira etapa metodologicamente orientada e de importância fundamental, porque dela depende o levantamento de hipótese possíveis sugeridas por um contato ainda superficial com o espaço concreto, mas suficientemente sugestivo para permitir a apreensão de imagens urbanas que atritam a atenção e permanecem, para o pesquisador com um desafio a ser respondido cientificamente, uma curiosidade que só será satisfeita quando a possibilidade daquelas hipóteses for superada pela generalização, capaz de 
explicar manifestações urbanas que ocorrendo repetidamente em lugares diversos, permitem uma aproximação de lugares em um espaço mais concreto e real (FERRARA, 1993, p.156).

A percepção, na análise das modificações da paisagem, lança questões sociais e individuais sobre os processos de modificação no meio. As ideias acerca de um tema podem se atrelar aos sentimentos que cada indivíduo tem com uma paisagem, gerando com isto um juízo perceptivo que permite, por meio da experiência, a continuidade, ou não, de certos costumes.

A Geografia, por meio da experiência social, interpreta os signos e ações culturais na paisagem. Neste contexto, a imagem fotográfica se tornou um recurso de análise das variações da paisagem ao longo do tempo, pois pode mostrar a leitura que a sociedade possui sobre a paisagem e também sobre as questões relacionadas ao seu imaginário espacial. Ao longo da ocupação espacial e desenvolvimento cultural, "o Homem estabeleceu um conjunto de práticas através das quais são criadas, mantidas, desfeitas e refeitas as formas e as interações espaciais" (CORRÊA, 1995, p.35), o ambiente vai sendo moldado para suprir as necessidades do ser humano e tais práticas podem alterá-lo como um todo ou apenas algumas parcelas do ambiente natural.

\subsection{A paisagem como reflexo de ações sociais}

Segundo Turri (2011, p.169) “é necessário restituir a paisagem ao campo das manifestações culturais e do universo representativo dos indivíduos e da sociedade". Assim segundo o autor supracitado, a mudança na paisagem reflete a ação antrópica, revelando "os significados subjetivos dos valores histórico-culturais que reflectem [sic] uma identidade territorial". Desta forma, é possível encontrar diferenças conceituais entre regiões distintas, como é o caso das definições americana e russa:

[...] whereas the concept of landscape in the English-speaking world has typically focused on landscapes as molded by humanity or as understood, perceived, and represented in different ways, the Russian approach has generally emphasized landscape's biophysical characteristics and its potential for utilization or transformation by humanity (SHAW; OLDFIELD, 2007).

Contudo, a interação/modificação do homem com o meio ambiente está cada vez maior e se dando de forma mais consolidada que se torna difícil fazer uma análise ambiental sem levar em consideração a ação antrópica. Assim, interpretação das modificações nas paisagens dependem da "capacidade que o ser humano possui de gerar 
informações a partir dos impactos ambientais urbanos que constituem seu cotidiano, a partir dessa produção, o ser humano conhece seu ambiente e é capaz de, sobre ele, produzir significados e ações" (FERRARA, 1993, p.264).

A partir disto, pode-se concluir que a percepção das modificações no meio depende não apenas do conhecimento que o indivíduo possui, mas também dos signos que este estabeleceu com o meio, dos seus sentimentos e das práticas sociais e culturais vivenciadas por este indivíduo. Desse modo, como defendem Fiorin (2002) e Saussure (2008), a experiência de vida de cada indivíduo apresenta uma interpretação para uma determinada paisagem, pois os elementos adquirem significados ao serem inseridos em contextos sociais/culturais. A importância atribuída à paisagem depende da percepção do indivíduo para com o meio, pois:

[...] Dentro da Geografia, a paisagem adquiriu um caráter polissêmico, variável entre as múltiplas abordagens geográficas adotas e dependente das influências culturais e discursivas entre os geógrafos (BRITTO; FERREIRA, 2011).

Neste sentido, deve-se ter em mente que "as cidades expressam a manifestação das particularidades culturais de um grupo, apresentando as transformações simbólicas de uma cultura através da temporalidade" (CAETANO; BEZZI, 2011, p.461). As cidades passam por modificações cada vez mais constantes e, antigas paisagens dão lugar a paisagens modernas e de usos muitas vezes diferentes dos anteriores, mudando desta forma os símbolos que lhes foram anteriormente atribuídos.

Azevedo (2013, p.151) afirma que "é importante dizer que a memória coletiva de uma sociedade está também expressa no seu espaço. Logo, quando um espaço é modificado, transformado de forma intensa, a memória também sofre mudanças, podendo ser fragmentada, confusa, ou ainda apagada".

As pesquisas realizadas por Mahdjoubi e Akplotsyi (2012) mostraram que a percepção ambiental exerce diferentes estímulos nas pessoas, e tal percepção pode modificar a forma com as pessoas interagem com o meio, fazendo com que umas estabeleçam uma relação mais intensa do que outros. Carvalho et al (2009) defendem a ideia de que quando o sujeito relaciona suas lembranças e vivências a um meio, ele resulta afirmando e/ou negando mais uma vivencia em função de outra, este fato estaria diretamente relacionado às experiências vividas naquele meio.

Silveira (2009, p.12) defende a ideia de que a emergência das questões ambientais está ligada "à perda da qualidade de vida dos seres humanos, devido ao 
caráter predatório e degradador do meio ambiente relacionado a uma apropriação desregrada da natureza, culminando na alteração constante das paisagens". Tendo como base tal ideia, é necessário ter a paisagem não apenas como uma condicionante de desenvolvimento, mas também de uma espécie de reflexo das ações da sociedade, pois segundo Silveira (2009, p.12), a paisagem “compõe aspectos culturais relevantes da sociedade, que exprime valores, posturas e a própria existência humana como ser explorador e ao mesmo tempo contemplador".

Na paisagem, segundo Turri (2011, p.173), "podemos encontrar o reflexo da nossa acção [sic], a medida do nosso viver e agir no território", o que faz com que sejamos, em parte, responsáveis pelas mudanças na paisagem local, pois à medida que estabelecemos relações sociais atribuímos valores a paisagem e acabamos mudando alguns locais para suprir as nossas necessidades. Contudo, deve-se levar em consideração que:

A paisagem não é a simples adição de elementos geográficos disparatados. É, em uma determinada porção do espaço, o resultado da combinação dinâmica, portanto instável, de elementos físicos, biológicos e antrópicos que, reagindo dialeticamente uns sobre os outros, fazem da paisagem um conjunto único e indissociável, em perpétua evolução.

É preciso frisar bem que não se trata somente da paisagem 'natural' mas da paisagem total integrando todas as implicações da ação antrópica [...] (BERTRAND, 2004, p.141).

Tal ideia se tornou cada vez mais aceita pelos geógrafos, pois é na paisagem que se observam as mudanças na vivencia social, assim como as consequências das estratégias econômicas, que acabam resultando em uma identidade territorial da sociedade com a paisagem local. Neste sentido, Turri (2011, p.176) estabelece uma relação entre a teoria dos sistemas e a paisagem, afirmando que "a paisagem seria o momento comunicativo entre dois sistemas, o sistema social e o sistema territorial. Para o sistema social em particular, a paisagem eleva-se a referência perceptiva, mediada pela cultura, pelo seu operar na natureza". Assim, as pesquisas sobre a interação homem-meio são cada vez mais importantes para entender as mudanças que ocorrem na paisagem, pois:

[...] Os estudos de paisagem servem como base para reordenamento de territórios, gestão e planejamento de recursos naturais por parte de organizações não governamentais e organismos oficiais. Além disso, essa categoria espacial insere-se 
na produção científica e orienta estudos e ações de diversos profissionais, ligados à arquitetura, agronomia, biologia/ecologia (SILVEIRA, 2009, p.13).

Em consonância com o exposto acima, a paisagem exerce uma "função de referente visual fundamental para os fins da construção territorial" (Turri, 2011), pois nela ocorre a interação de um espaço sem significado/vazio de sentimento para se transmutar na paisagem que, após a interação cultural, agrega símbolos e sentimentos. As modificações na paisagem serviriam para garantir a sobrevivência e o desenvolvimento da sociedade. No que tange a percepção ambiental vivida pela sociedade,

A paisagem enquanto suporte material das lembranças assenta afetividade e efetiva acontecimentos, grupos sociais e saberes-fazeres, guarda as marcas do tempo, o movimento da história. Identidade é enraizamento, é sobreposição de objetos e ações e identificação com estes mesmos elementos; a paisagem-memória cumpre esse papel de enraizar para afagar a alma humana com receio de se perder ante a coletividade a fugacidade do mundo. Por um lado, se a paisagem é material, por outro, sua função é a de alimentar o subjetivo. Ela indica as correntezas das relações do passado e preserva as tradições técnicas no presente para, sobretudo, dar corpo a um imaginário sobre objetos, lugares e grupos a serem mantidos nas lembranças do futuro. As iconografias podem cumprir o papel de registro, de preservar, então, a sabedoria, os desejos, as necessidades, cumprir as técnicas e a ética sociais; preservar a paisagem cultural da humanidade é preservar singulares sentidos da vida material e intersubjetiva; é uma prática em defesa da memória social (COSTA, 2014, p..82-83).

Os usos que se dão a uma determinada paisagem, além de sua questão funcional, constroem a identidade social de uma região, onde o cotidiano pode gerar diferentes percepções sobre uma mesma paisagem. E, com o decorrer do tempo, a paisagem pode ser tornar cada vez mais inseparável a um sentimento, pois os usos e hábitos estabelecem uma ligação intima com o local e com seus símbolos e códigos.

A percepção ambiental deve estar ligada, às informações contidas nos símbolos e interações antrópicas estabelecidas com o meio natural, sobretudo ligada a desconstrução destes códigos e sentimentos intrínsecos a paisagem.

To become more socially relevant, landscape planners must become aware of, account for, incorporate, and challenge the problems and opportunities that cultural adoptability, economic viability, social equitability, and political relevancy have on the ecological condition of our landscapes. For although natural processes largely 
determine the ecological condition of our landscapes, social processes will continue to determine the directionality these processes take. Since the fate of our landscapes lies so squarely on the lap of society, it is imperative that our research move beyond our traditional descriptions of space, our academic divisions, and our rational methods (LINEHAN; GROSS, 1998).

As paisagens e a cultura de uma determinada região direcionam as mudanças que ocorrem em uma dada região e, como defende Bignante (2011, p.5):

[...]D’altra parte, benché forse in maniera meno invasiva rispetto a oggi, l'uomo è da sempre immerso in una cultura visuale. Le immagini giocano, oggi come in passato, un ruolo rivelante nell'influenzare mode, nel consolidare percezioni, nel trasmettere informazioni, nel costruire modalità di osservazione della realtá.[...].

As observações da paisagem demandam cada vez mais a utilização de diferentes abordagens, métodos cada vez mais complexos e ligados a questões de percepção e cultura. Portanto, as imagens são elementos necessários no estudo da paisagem, pois através delas pode-se estabelecer uma cronologia das modificações na paisagem e, consequentemente, dos acontecimentos sociais vividos pela população.

A paisagem pode ser entendida como resultante de inter-relações entre diversas unidades ambientais e sociais, onde de acordo com a Teoria Geral de Sistemas ${ }^{2}$ empregada por Christofoletti (1979) o grau de organização de um conjunto permite que este assuma uma função de que um todo é maior que a soma das partes. Esta teoria fez com que os estudos geográficos centralizassem suas pesquisas e dessem maior exatidão a seus estudos, além de propiciar oportunidade para reconsiderações críticas de muito dos seus conceitos. Desse modo:

As paisagens constituem respostas a um complexo de processos, cada um exigindo apropriadas escalas espacial e temporal para serem estudados. $\mathrm{Na}$ esculturação das formas de relevo essa complexidade é descrita pelas inúmeras variáveis envolvidas, havendo entre elas interação, interdependência e mecanismos de retroalimentação (CHRISTOFOLETTI, 1980, p.171).

Contudo, é importante salientar que o conhecimento acerca de alguns eventos naturais "sempre é imperfeito porque se expressa através dos recursos de determinada

\footnotetext{
${ }^{2}$ A Teoria Geral de Sistemas (TGS) surgiu com as pesquisas do biólogo alemão Karl Ludwig von Bertalanffy. Com esta Teoria, ele queria mostrar que o organismo é um todo maior que a soma das suas partes.
} 
linguagem. Cada linguagem apresenta possibilidades diferentes para a descrição e explicação dos fenômenos observados" (CHRISTOFOLETTI, 1980, p.176). A paisagem se vincula à um período de transformações na sociedade, mostrando a apropriação e a modificação do espaço.

Para Cosgrove (1998) a paisagem seria uma forma material que resulta da ação humana sobre a natureza primeira, em que ela deve ser sempre analisada juntamente às transformações econômicas, sociais, políticas e ambientais. Os principais problemas enfrentados nesta correlação é "identificar os elementos, seus atributos e suas relações, a fim de delinear com clareza a extensão abrangida pelo sistema em foco" (CHRISTOFOLETTI, 1980, p.2), mas é importante frisar que um elemento não necessariamente exerce uma hierarquia de importância sobre outro, sendo assim, todos devem ser analisados de forma igualitária.

\subsection{Paisagem e iconografia}

As fotografias representam a realidade vivida, a realidade selecionada, o olhar do indivíduo sobre algo. As informações contidas nas fotografias podem ter diferentes finalidades, mas de uma forma geral, expressam informações sociais e/ou ambientais, além de provocar no observador diferentes reações.

O fotógrafo exprime o seu olhar sobre a paisagem e a fotografa, mostrando nesta a sua visão de mundo. Neste sentido, "a fotografia não apenas reproduz o real, recicla-o - um procedimento fundamental numa sociedade moderna. $\mathrm{Na}$ forma de imagens fotográficas, coisas e fatos recebem novos usos, destinados novos significados, que ultrapassam as distinções entre o belo e o feio, o verdadeiro e o falso, o útil e o inútil, bom gosto e mau gosto" (SONTAG, 2004, p191).

A fotografia tem o poder de gerar no observador questionamentos acerca de algo, seja a fotografia utilizada como arte ou como meio de informação, pois ao ver a fotografia começa-se a pensar os pensamentos que levaram o fotógrafo a posicionar tal ângulo e tal olhar ao invés de outros.

Contudo, "o geógrafo deveria estabelecer para o uso da fotografia um compromisso desafiador. [...] O desafio seria o de empregá-la com vistas a uma análise crítica” (REIS JÚNIOR, 2014, p.32). Assim, Aumont (2011) sugere que a fotografia exerce funções psicológicas e, ao acentuar o real, estabelece a criação de códigos 
sociais, culturais e ambientais. Em consonância com estas ideias, Bignante (2011, p. 11) afirma que:

A lungo, dunque, il ruolo giocato dalle immagini, e dalla fotografia in particolare, nell'analisi geografica à stato soprattutto quello di produrre, attraverso l'osservazione, descrizioni visive il più possible complete e pertanto <<scientifiche〉>. Oggi tuttavia la geografia, prese le distanze dalla ricerca di un'oggettività scientifica nel proprio operare, in più modi ha messo in discussione la possibilità di produrre descrizioni definitive ed esaustive del mondo.

As fotografias mostram, ou ampliam, a realidade e produzem um sentimento de pertencimento a uma dada região, pois "não se pode possuir a realidade, mas pode-se possuir imagens (e ser possuído por elas) [...] Possuir o mundo na forma de imagens é, precisamente, reexperimentar a irrealidade e o caráter distante do real" (SONTAG, 2004, p.180), a realidade, por meio das fotografias, passaria a fazer parte das lembranças de cada indivíduo. A documentação iconográfica se torna cada vez mais relevante para se conhecer as relações antrópicas estabelecidas com o meio no período passado mostrando, principalmente, a história vivida e produzida.

O contexto social e geográfico preserva a memória de um determinado tempo e espaço, e na fotografia é possível ver as influências passadas pela paisagem. Tais imagens acabam se tornando "documentos para a história e também para a história da fotografia" (KOSSOY, 1989, p.16), pois o seu conteúdo mostra as interações homemmeio ao longo do tempo.

Ao reconhecer a realidade por meio das fotografias, o indivíduo pode se encontrar e reencontrar numa determinada paisagem, seja ela vivida em algum período de sua vida ou até mesmo imaginada, resultando numa "satisfação psicológica pressuposta pelo fato de "reencontrar" uma experiência visual em uma imagem, sob forma ao mesmo tempo repetitiva, condensada e dominável" (AUMONT, 2011, p.83). Neste momento, há uma representação da paisagem que proporciona diferentes formas de ver uma fotografia.

No que tange a realidade, Kossoy (2002, p.36-37) a classifica como primeira realidade e segunda realidade, em que:

A primeira realidade é o próprio passado. A primeira realidade é a realidade do assunto em si na dimensão da vida passada; [...] É também a realidade das ações e técnicas levadas a efeito pelo fotógrafo diante do tema - fatos estes que ocorrem ao longo do seu processo de criação - e que culminam com a gravação da aparência do 
assunto sobre um suporte fotossensível e o devido processamento da imagem, em determinado espaço e tempo. São estes, fatos diretamente conectados ao real. [...] Findo o ato a imagem obtida já se integra numa outra realidade, a segunda realidade.

A segunda realidade é a realidade do assunto representado, contido nos limites bidimensionais da imagem fotográfica, não importando qual seja o suporte no qual esta imagem se encontre gravada. [...] A segunda realidade é, a partir do conceito acima, a realidade de fotográfica do documento, referência sempre presente de um passado inacessível.

A paisagem, ao retratar sempre fatos passados, pois o instante fotografado não poderá mais voltar, se torna um importante instrumento de análise das modificações na paisagem, sejam elas naturais ou não. $\mathrm{Na}$ geografia, ela pode ser empregada de diferentes modos para pesquisa e de diversos usos, pois "le immagini, come si è detto, più che mostrare il mondo ne propongono tante, diverse, interpretazioni e escondo come le utilizziamo nell'attività di ricerca si permetteranno di leggere, studiare e analizare la realità e modalità differenti” (BIGNANTE, 2011, p.14).

Contudo, mesmo tendo um caráter científico, o evento deve ser fotografado até se completar e finalizar o pensamento originalmente definido pelo fotógrafo, pois isto faz com que não haja uma quebra de acontecimentos lógicos e encadeados definidos pelo fotógrafo.

Ao se fotografar uma paisagem, o fotógrafo pode interferir na imagem resultado, destacar algum fator ou ignorar algo. Assim, a "imagem pode ser entendida como uma das mediações do homem com o seu mundo, pois as imagens apresentam o mundo acessível e inacessível pela tradução de códigos capazes de decifrar eventos" (STEINKE, 2014, p.46).

Neste momento, o senso do fotógrafo seleciona situações e lugares, assim como julga os eventos como dignos ou não de serem fotografados. E, apesar de todo este processo de construção e desconstrução de um objeto e pensamento, "a foto ainda existirá, conferindo ao evento uma espécie de imortalidade (e de importância) que de outro modo ele jamais desfrutaria" (SONTAG, 2004, p.21-22).

A principal limitação da fotografia está no fato de esta não retratar a realidade como um todo, mas sim paisagens selecionadas e pré-definidas de um todo. Ao se analisar fotografias, é relevante não se ater apenas a imagem em si, e sim relacioná-la com fatores culturais e sociais, de vivencia e de produção de espaços. 
Ao mesmo tempo que a fotografia exprime recortes espaciais e temporais da realidade, ela gera uma linguagem visual resultante da escolha do objeto e da percepção do fotógrafo. Dessa forma, os fotógrafos (fotogeógrafos) que pretendem expressar um cunho social conscientizador e/ou problematizador supõem que seus registros imagéticos tem o poder de relevar a verdade.

Contudo, "por ser a fotografia sempre um objeto num contexto que molda qualquer uso imediato da fotografia - em especial o político - é imediatamente seguido por contextos em que tais usos são enfraquecidos e se tornam cada vez menos relevantes" (SONTAG, 2004, p.122).

A imagem-foto, apresenta um caráter próprio tanto do fotógrafo como da paisagem, e mostra um resultado que visa fornecer informações pré-pensadas e selecionadas, ou seja, a fotografia mostra uma aquisição de conhecimento já pensado pelo fotógrafo, onde este, através de seus símbolos e vivências direciona a lente da câmera ao que mais lhe interessa no momento a ser fotografado.

A fotografia, de acordo com o seu uso posterior, também funciona como um "registro da aparência dos cenários, personagens, objetos, fatos; documentando vivos ou mortos, é sempre memória daquele preciso tema, num dado instante de sua existência/ocorrência" (KOSSOY, 2007, p.131). No momento posterior ao apertar do botão da máquina fotográfica, a fotografia já se torna um código, um vestígio da realidade passada num dado contexto espacial e temporal.

Durante o processo de fotografar, o objeto se torna único, mas não sua análise posterior, pois cada indivíduo ao olhar uma fotografia pode, devido sobretudo à sua cultura, analisar uma fotografia de forma diferente da pensada pelo fotógrafo durante o seu processo de produção. Mostrando desta forma que, apesar de cada fotografia ter "sua origem a partir do desejo de um indivíduo que se viu motivado a congelar em imagem um aspecto dado do real, em determinado lugar e época" (KOSSOY, 1989, p.22), ela pode resultar em diversas interpretações sobre um mesmo objeto.

Contudo, não se pode esquecer de que "embora a câmera seja um posto de observação, o ato de fotografar é mais do que uma observação passiva" (SONTAG, 2004, p.22) ela também exprime os sentimentos do fotógrafo para com o local que foi escolhido.

Igualmente, a imagem retida pelas lentes dos fotógrafos, "fornece o testemunho visual e material dos fatos aos espectadores ausentes na cena. A imagem fotográfica é o 
que resta do acontecido, fragmento congelado de uma realidade passada, informação maior de vida e morte, além de ser produto final que caracteriza a intromissão de um ser fotógrafo num instante do tempo "(KOSSOY, 1989, p.22).

A fotografia, por meio da imagem gerada sobre uma paisagem, tem o poder de conter "em si um inventário de informações acerca de um determinado momento passado; ela sintetiza no documento um fragmento do real visível, destacando-o do contínuo de vida" (KOSSOY, 1989, p.69).

No processo e selecionar o objeto a ser fotografado, há o conflito entre objetividade e subjetividade, pois "embora a autoridade de uma fotografia sempre dependa da relação com um tema (de ser a foto de alguma coisa), todas as pretensões fotográficas como arte devem enfatizar a subjetividade da visão" (SONTAG, 2004, p.152), fazendo com que, por mais que tenha um caráter técnico, a fotografia tirada também pode ser encarada uma forma de arte.

O tempo é um dos principais responsáveis por evidenciar as práticas cotidianas, as interações sociais e a individualidade de cada ser na construção do imaginário espacial. Neste sentido, a fotografia tem o poder de mostrar as modificações visuais ocorridas no cotidiano social, pois em um dado momento "se pode encontrar o elo entre a cotidianidade e a fotografia, a fotografia como representação sócia e memória do fragmentário, que é o modo próprio de ser da sociedade contemporânea" (MARTINS, 2008, p.36). Portanto, a fotografia pode ser vista também como um elemento capaz de estabelecer um sentimento de continuidade de mudanças e do cotidiano social.

A fotografia proporciona ao sujeito uma revelação da realidade, muitas vezes como esta não era vista antes, dando assim um caráter revelador à fotografia. Assim, "na observação da representação da imagem capturada da realidade, utilizamos e expandimos nossa imaginação para análise e interpretação do momento, objeto ou fato registrado, na busca por explicações" (SOUZA; SOUZA, 2013, p.110).

Desta forma, além do caráter artístico da fotografia, ela adquire uma função de "imagem refletida da realidade", servindo como uma espécie de testemunha ou evidencia de algo, fazendo com que haja análises do cotidiano com as práticas de vivências culturais e ambientais.

A fotografia cria um sentimento de pertencimento à medida que o ser a analisa, fazendo com que a memória crie um arquivo visual ligada à sentimentos e ao conhecimento de mundo. 
No entanto, Kossoy (2002, p.45) sugere que "uma vez assimiladas em nossas mentes, deixam de ser estáticas; tornam-se dinâmicas e fluidas e mesclem-se ao que somos, pensamos e fazemos. Nosso imaginário reage diante das imagens visuais de acordo com nossas concepções de vida, situação econômica, ideologia, conceitos e préconceitos". O sentimento associado a uma determinada fotografia e interpretação desta faz com que a fotografia se torne cada vez mais um elemento necessário ao cotidiano, pois

A fotografia reforça a necessidade de representar. Nas fotografias, as pessoas fazem supor. Ao mesmo tempo, a fotografia se propõe como apontamento da memória, e não como memória, como lembrete do que se perdeu no cotidiano, na banalização, na secundarização de certos acontecidos, e não se quis perder (MARTINS, 2008, p.43).

Contudo, "como cada foto é apenas um fragmento, seu peso moral e emocional depende do lugar em que se insere. Uma foto muda de acordo com o contexto em que é vista [...] Cada uma dessas situações sugere um uso diferente para as fotos mas nenhuma delas pode assegurar seu significado" (SONTAG, 2004, p.122) e assim, o pensamento primeiro do fotografo pode ser interpretado de maneira não apenas equivocada, mas também de forma a não seguir a sua linha de raciocínio estabelecida durante o momento em que fotografava o objeto.

As imagens têm o poder de produzir em cada indivíduo uma reação diferente, pois a percepção depende da vivência de cada ser. Assim, as imagens podem também provocar impactos diferentes em cada ser e “é impossível haver 'interpretações-padrão' sobre o que se vê registrado nas imagens" (KOSSOY, 2002, p.46).

A dualidade de significados gerada pelas fotografias, mencionada anteriormente, resulta em uma ilusão criada pelo espectador que acaba por enganá-lo do real significado da fotografia. Neste sentido, "é claro que a maioria das imagens comporta elementos que, tomados isoladamente, pertencem ao domínio da ilusão. É o caso, em nível, microanalítico, de todas as ilusões 'elementares' presentes nas imagens" (AUMONT, 2011, p.99).

O geógrafo durante o seu processo de investigação, ao utilizar as fotografias em suas pesquisas, é relevante observar detalhadamente o seu objeto e descrevê-lo da forma mais natural possível para que haja o mínimo possível de dualidade nas interpretações de terceiros. 
A fotografia, por apresentar características materiais e subjetivas, mostra a paisagem como "o resultado da interação entre materialidade das formas e o sentimento que desperta nas pessoas que a observam e a vivenciam no cotidiano de suas vidas" (CAETANO; BEZZI, 2011) e com isto, pode-se dizer que "o estudo da paisagem pode ser realizado através do método iconográfico, que comtempla a análise dos símbolos e signos de uma determinada cultura" (SONTAG, 2004, p.26), pois a partir de tais correlações é possível analisar a paisagem e suas modificações de uma forma completa.

Ao longo do tempo, o sentimento que um indivíduo estabelece com um determinado lugar pode mudar, e por meio da fotografia, sua memória pode ser perpetuada. O sentimento, o saudosismo de uma época e de um lugar, de pessoas e animais pode ser lembrado por meio das fotografias, em que esta mostra o "espaço recortado, fragmentado, o tempo paralisado; uma fatia de vida (re)tirada de seu constante fluir e cristalizada em forma de imagem" (KOSSOY, 2007, p.133). A fotografia seria então "o efêmero e o perpétuo, [...], onde o elo imagético, codificado formal e culturalmente, persiste em sua trajetória na longa duração" (KOSSOY, 2007, p.133).

Portanto a observação da paisagem e suas alterações, tornou-se de suma importância para pesquisadores que trabalham com o território e questões ambientais. Como consequência dessa importância, a fotografia transformou-se em um mecanismo para estabelecer tal análise, pois pode "revelar" a paisagem em transformação ao longo do tempo e a interação estabelecida entre a sociedade e o meio ambiente com o qual se relaciona. 


\section{PROCEDIMENTOS METODOLÓGICOS}

A presente pesquisa teve como aporte metodológico os elementos referentes a paisagem, a fotografia, as políticas educacionais brasileiras e a geografia escolar. Estes elementos foram analisados de forma encadeada e interdependente. A paisagem analisada foi a da bacia hidrografia do rio Corrente pois, mostra o sistema como um todo e, nesta bacia foram analisadas as modificações na paisagem por meio das fotografias produzidas por alunos do Ensino Fundamental II. A escolha deste grupo amostral se deve ao fato de os Parâmetros Curriculares Nacionais - PCN direcionarem o estudo da paisagem e suas modificações para o $7^{\circ}$ ano do Ensino Fundamental.

A bacia hidrográfica do rio Corrente foi selecionada como área de estudo por ser uma unidade de planejamento ambiental que integra ambientes variados, onde elementos naturais e antrópicos se relacionam, sendo considerada por pesquisadores ambientais como uma boa unidade de manejo. "[...] A escolha da microbacia hidrográfica como tema gerador exige a pesquisa sobre quais são, como interagem e como são utilizados os elementos presentes na área da mesma, para que se possa compreender a dinâmica do sistema. Assim, a educação pela pesquisa se torna essencial" (LUCATTO; TALAMONI, 2007, p.392). Para Christofoletti (1980, p.102) “drenagem fluvial é composta por um conjunto de canais de escoamento interrelacionados que formam a bacia de drenagem, definida como a área drenada por um determinado rio ou por um sistema fluvial", neste sentido, a bacia hidrográfica estudada neste artigo é formada pelo principal rio que passa pelo município, o rio Corrente.

Tendo em vista as interações antrópicas e o conhecimento que os alunos devem ter sobre as questões ambientais, foi realizada inicialmente um levantamento acerca dos temas e conhecimentos que os alunos deveriam ter em algumas fases do ciclo escolar de acordo com os Paramentos Curriculares Nacionais, gerando como uma das abordagens a pesquisa-ação e atividades de campo.

No trabalho de campo foram selecionados os seguintes elementos: o rio, a vegetação e alguns elementos socioeconômicos. A fotografia foi utilizada como um meio para mostrar as modificações na paisagem, pois esta mostra como se dão as interações homem-meio ao longo do tempo, além de mostrar como algumas práticas educacionais podem ser aplicadas no estudo da paisagem. Os alunos produziram 1.267 fotografias que serão analisadas posteriormente. 
Figura 1: Mapa conceitual da pesquisa.

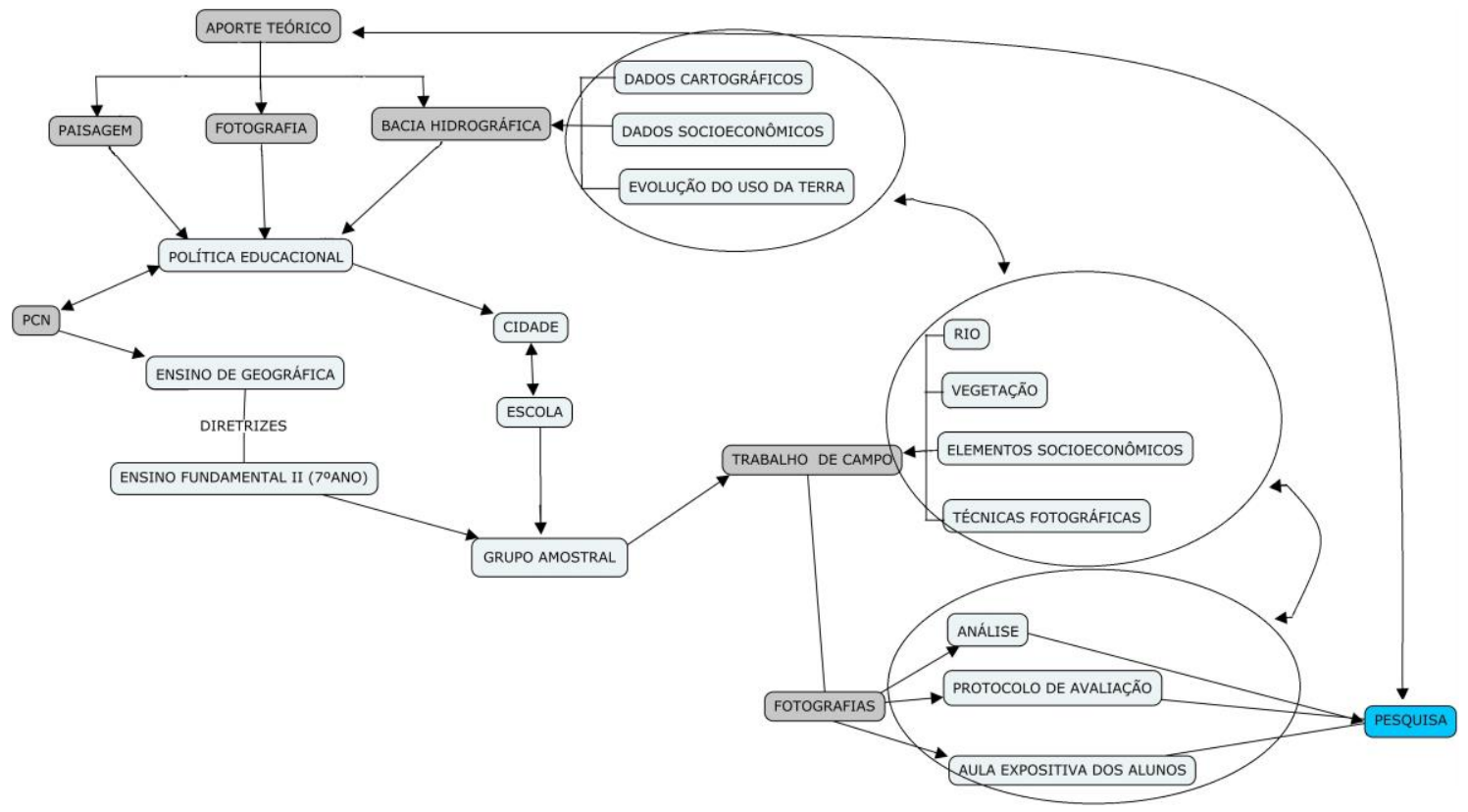

Fonte: NASCIMENTO, 2016.

Tendo como focos a paisagem, a fotografia e a bacia hidrográfica, ambos definidos por meio do aporte teórico que guiou esta pesquisa, houve a necessidade de saber o que e como a política educacional brasileira abordava destes elementos, assim como também em qual série os elementos geográficos analisados nesta pesquisa seriam estudados. A definição do perímetro urbano se baseou no fato de ser mais fácil para o transporte dos alunos, pois a escola se localiza relativamente próxima ao rio. Assim, foi realizado o trabalho de campo e os alunos fotografaram os elementos/características que mais lhes chamaram a atenção durante o trajeto. Todos estes elementos resultaram na presente pesquisa.

Os alunos foram direcionados a interagirem com o meio pois, segundo Turri (2011), quando o homem se coloca na condição de espectador é possível interagir com o meio de forma planejada. Logo, o homem deve notar as mudanças que pode fazer no meio para posteriormente conhecer e agir sobre o mesmo. "El lugar es el conocimiento construido en el tiempo que cada individuo tiene del espacio que habita. Lugar es el espacio vivido, cotidiano, que tiene sentido de identidad y pertenencia" (VALENCIA et al, 2013, p.58).

Ao se colocar na condição de espectador e de ator, o homem consegue estabelecer as consequências de suas ações no meio ambiente. Neste sentido, a metodologia foi pensada de forma a fazer com que os alunos pudessem entender as 
modificações na paisagem e também a pensarem, enquanto cidadãos críticos, no quanto a paisagem muda ao longo do tempo.

\subsection{Caracterização da área de estudo}

O município de Corrente se localiza no estado do Piauí, no Brasil. Situa-se

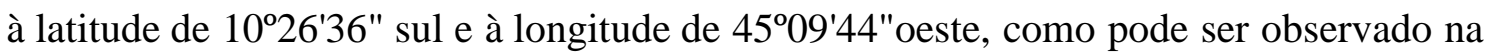
figura 2. Corrente pertence a Chapadas do Extremo Sul Piauiense, e segundos dados do senso Instituto Brasileiro de Geografia e Estatistica - IBGE (2010), a população de Corrente-PI era de 25.407 habitantes, com uma área de unidade territorial de $\mathrm{km}^{2}$ 3.048,446. A vegetação nesta região é majoritariamente composta por campo cerrado e caatinga arbórea e arbustiva (SANO et al, 2010). O clima é caracterizado como tropical subúmido quente, com duração do período seco de cinco meses.

De acordo com o IGBE (2010), em 1754, Corrente teve seus terrenos divididos por ordem do Rei de Portugal, tendo como primeiro nome Fazenda Corrente de Cima, onde foram desenvolvidas atividades que atraíram um grande número de pessoas, dando início ao povoamento da região. Ainda segundo esta fonte,

Com o seu desenvolvimento e, em consequência da Lei provincial $\mathrm{n}^{\circ} 782$, de $10 \mathrm{de}$ dezembro de 1872, o povoado foi elevado à categoria de vila, cuja instalação só se deu a 8 de dezembro do ano seguinte [...] De 1922 a 1924, Corrente sofreu as consequências da ação de bandoleiros, que então se verificou, tendo de um lado José Honório Granja, e de outro lado José Nogueira. Passando essa fase, Corrente tomou o seu desenvolvimento e, em 1947, foi criado o Ginásio do Instituto Batista Industrial. Em 1949, foi criado o Educandário Imaculada Conceição e, em 1953, o Ginásio São José pelo Padre José de Anchieta Melo, que chegou em fins de 1947 ao município, para assumir os trabalhos da Paroquia. Como se vê, a instrução constitui o ponto de referência da evolução histórica e de desenvolvimento de Corrente.

O estudo das principais modificações nesta bacia se dará principalmente pelas relações existentes em seu sistema, seja ambiental ou cultural, sendo imprescindível para tanto a análise das modificações na paisagem em diferentes escalas. 
Figura 2: Área de estudo

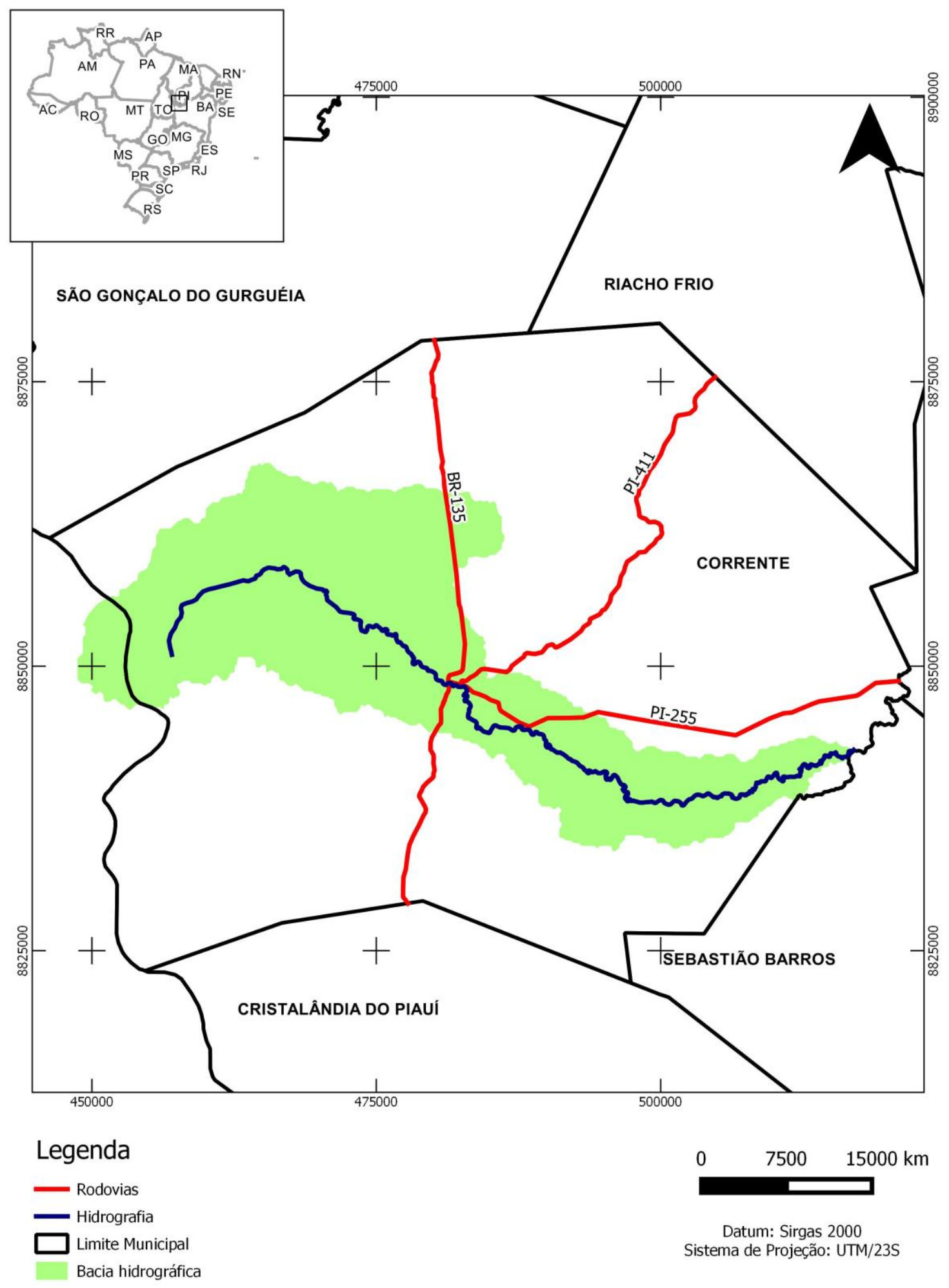

Fonte: NASCIMENTO, 2016. 
A produção agrícola do municipio de Corrente-PI, apresenta uma relativa diversidade, de acordo com o os dados do IBGE (2013), que pode ser observada nos quadros 1 e 2 .

Quadro 1

\section{A produção agrícola municipal - lavoura temporária}

\begin{tabular}{|l|l|}
\hline $\begin{array}{l}\text { A produção agrícola municipal - lavoura temporária - 2004 tem como seus maiores } \\
\text { exponentes }\end{array}$ & 612 toneladas \\
\hline Arroz (em casca) - quantidade produzida & 850 hectares \\
\hline Arroz (em casca) -área plantada & 3.600 toneladas \\
\hline Mandioca - quantidade produzida & 300 hectares \\
\hline Mandioca - área plantada & \\
\hline A produção agrícola municipal - lavoura temporária - 2013 tem como seus maiores \\
exponentes
\end{tabular}

Fonte: IBGE, 2013.

Quadro 2

\section{A produção agrícola municipal - lavoura permanente}

\begin{tabular}{|l|l|}
\hline $\begin{array}{l}\text { A produção agrícola municipal - lavoura permanente - 2004 tem como seus maiores } \\
\text { exponentes }\end{array}$ & 470 toneladas \\
\hline Manga - Quantidade produzida & 47 hectares \\
\hline Manga - Área destinada à colheita & 300 toneladas \\
\hline Banana - Quantidade produzida & 30 hectares \\
\hline Banana - Área destinada à colheita & \\
\hline A produção agrícola municipal - lavoura permanente - 2013 tem como seus maiores \\
\hline
\end{tabular}




\begin{tabular}{|l|l|}
\hline \multicolumn{2}{|l|}{ exponentes } \\
\hline Banana (cacho) - Quantidade produzida & 130 toneladas \\
\hline $\begin{array}{l}\text { Banana (cacho) - Área destinada à } \\
\text { colheita }\end{array}$ & 20 hectares \\
\hline Manga - Quantidade produzida & 112 toneladas \\
\hline Manga - Área destinada à colheita & 20 hectares \\
\hline
\end{tabular}

Fonte: IBGE, 2013.

De acordo com as tabelas acima é possível notar que a produção agrícola na região passou por mudanças consideráveis em seus maiores exponentes. Quanto a lavoura temporária, o cultivo da soja, no ano de 2013, ocupa a maior área de cultivo no município. No que tange a lavoura permanente, a manga e a banana continuam sendo os maiores representantes desde o ano de 2004 a 2013.

\subsection{Seleção dos alunos}

Os Parâmetros Curriculares Nacionais (PCN, 1998, p.55) afirmam que dentre os objetivos para o terceiro ciclo, “espera-se que os alunos sejam capazes de: Perceber na paisagem local e no lugar em que vivem, as diferentes manifestações da natureza, sua apropriação e transformação pela ação da coletividade, de seu grupo social; Saber utilizar a observação e a descrição na leitura direta ou indireta da paisagem, sobretudo mediante ilustrações e linguagem oral. ” Assim, tendo como base os PCN (1998), foram selecionados alunos do $7^{\circ}$ ano do Ensino Fundamental da Unidade Escolar Desembargador João Pacheco Cavalcante, no município de Corrente-PI.

Tendo como base o convívio escolar/social e os procedimentos estabelecidos pelos PCN (1998), Oliveira e Kunz (2014) defendem a ideia de que:

[...] Cabe ao professor a condução ou o apoio à organização do conhecimento e, ao mesmo tempo, a busca pelo aprendizado dessa nova produção do mundo, contribuindo para um direcionamento útil das coisas, conhecimento aplicado segundo as necessidades da sociedade como uma totalidade. Assim também, avaliando e aprendendo com as consequências positivas e negativas das contradições inerentes dos processos e práticas 
resultantes destas ações numa práxis libertadora (OLIVEIRA; KUNZ, 2014, p.139).

Nesta mesma ótica, Paulo Freire (1996, p.113) sugere ao educador estabelecer o diálogo com seus alunos, pois "o educador que escuta aprende a difícil lição de transformar o seu discurso, às vezes necessário, ao aluno, em uma fala com ele".

A realização desta investigação teve como principal agente as crianças do $7^{\circ}$ ano, visa pesquisar também como elas se relacionam com o espaço vivido, uma vez que muitas moram em casas construídas próximas ao leito do rio. Assim, as crianças deveriam descontruir o "rito do cotidiano", de frequentarem e viverem na paisagem a ser estudada, pois pelo fato de passarem diariamente por esta paisagem o seu olhar pode acabar se acostumando a ela e com isto eles poderiam não analisar a paisagem de forma crítica. Desta forma,

Para apreender a informação do espaço, é necessário fragmentá-la, transformando-o em lugar informado. É necessário ultrapassar aquela totalidade homogênea do espaço para descobrir seus lugares nos quais a informação se concretiza, na medida em que produz aprendizado e comportamento traduzidos nos seus signos: usos e hábitos. De um espaço de informação evoluímos para um lugar informado (FERRARA, 1993, p.153).

Aumont (2011, p.109) afirma que o espectador estabelece uma relação com a imagem, e esta relação possui "uma espacialidade referente à estrutura espacial em geral; tem além disso uma temporalidade referente aos acontecimentos representados e à estrutura temporal que deles decorre".

A escolha de se trabalhar as modificações da paisagem com os alunos busca quebrar o paradigma hierárquico da concentração do saber, principalmente aquele estabelecido de maneira formal e tradicional. Ao se empregar este método de pesquisaação, os alunos valorizam as suas impressões pessoais sobre a realidade e mostram, por meio das fotografias, as suas opiniões e posicionamentos frente às mudanças que estão vivendo no e com o meio. Espera-se com isto que os alunos mostrem sua autonomia e que se tornem indivíduos comprometidos com seus espaços produzidos contribuindo para sua formação como pessoas comprometidas com a preservação, transformação e valorização dos espaços geográficos. 


\subsection{O método}

Para o desenvolvimento da atividade de campo, foram realizados acompanhamentos dos alunos na escola, aula teórica sobre conceitos geográficos e ambientais, além de saída de campo em um trecho da área urbana da bacia hidrográfica e aplicação de um protocolo para a averiguação de características ambientais da bacia hidrográfica e apresentação dos resultados pelos estudantes aos demais alunos da escola e a comunidade.

A atividade de campo foi dividida em dois momentos: o primeiro, em que foi realizada uma saída de campo, com os alunos selecionados, em parte da bacia hidrográfica, dentro do perímetro urbano da cidade; e o segundo, em que foi realizada uma oficina na escola com os alunos, em que foram feitas algumas análises de fotos préselecionadas que foram registradas pelos alunos durante o primeiro campo.

Houve uma pesquisa documental e fotográfica nos arquivos que a Prefeitura Municipal de Corrente possuía sobre o rio Corrente e também um levantamento realizado junto a população correntina, pois "as representações fotográficas contêm em si informações iconográficas cobre o dado real e, em função disso, são de grande valor para a pesquisa e interpretação nas ciências humanas, exatas e biológicas" (KOSSOY, 2007, p.40).

O recorte espacial foi delimitado de acordo com as fotografias, desta forma, o recorte temporal acabou sendo delimitado por aproximadamente 50 anos, data aproximada da fotografia mais antiga do rio que foi encontrada na Prefeitura Municipal de Corrente-PI. Contudo, para a atividade de campo com os alunos foi considerado um trecho de aproximadamente $1 \mathrm{~km}$ dentro do perímetro urbano. Este trecho foi selecionado através de uma visita prévia para reconhecimento da área, pois era preciso delimitar o trajeto mais seguro para caminhar com os alunos.

Nesta primeira atividade, os alunos realizaram uma saída de campo em parte da bacia hidrográfica, e foram tirando fotografias dos lugares que mais lhe chamavam a atenção, que continham desmatamento e danos causados pela ação antrópica. A intenção foi fazer com que as crianças percebessem as modificações no meio que foram causadas por ação humana, olhando o cotidiano com uma visão mais crítica e consciente que anteriormente. 
$\mathrm{Na}$ segunda etapa a atividade, foi proposta e realizada uma oficina pedagógica na escola com os alunos que participaram do primeiro campo. Os alunos foram convidados a analisarem uma seleção de fotografias tiradas por eles e também a responder uma ficha de análise para avaliação de elementos presentes em cada foto. Posteriormente os alunos foram convidados a exporem os seus trabalhos na escola, mostrando para outros alunos suas experiências vividas durante a realização do primeiro campo e também da avaliação das fotografias.

O protocolo (APÊNDICE A) foi aplicado como um meio de avaliação dos alunos para com o meio em que tiveram contato. Este método de avalição visual teve como principal objetivo fazer com que os alunos reconhecessem as áreas mais críticas que viram na saída de campo, podendo fazer com que eles avaliassem os diversos impactos ambientais presentes na área. Este protocolo pode constituir "uma ferramenta na avaliação rápida da diversidade de habitats em trechos de bacias hidrográficas brasileiras" (CALLISTO et al, 2002, p.97), pois para responder ao protocolo, os alunos tiveram que aprender alguns conceitos-chave da geografia e realizaram uma saída de campo a região para fazer um reconhecimento da área a ser analisada.

Esta segunda atividade foi realizada com o intuído de fazer com que os alunos assimilassem melhor os conceitos estudados na primeira saída de campo e também fazer com que estes mostrassem o trabalho que eles realizaram para a comunidade escolar, realizando uma maior discussão acerca do assoreamento da bacia do rio Corrente.

Assim como sugere Mahdjoubi e Akplotsyi (2012), este protocolo foi adaptado de acordo com a legislação educacional vigente, no caso brasileiro os Parâmetros Curriculares Nacionais e pode ser utilizado para mostrar a situação que os alunos perceberam da área em que foi realizado o campo.

\subsection{A técnica}

As crianças, nesta pesquisa, foram entendidas como agentes críticos acerca das modificações na paisagem localizada na bacia hidrográfica no perímetro urbano. Assim, as fotografias que elas registraram na saída de campo, refletem como leem a paisagem e como a sociedade habita e se relaciona com a região. Desta forma, a fotografia, neste estudo, tem como principal característica mostrar as modificações nos usos e consequentemente, na paisagem local, pois “por serem também imagens, algumas fotos 
nos reportam, desde o início, tanto a outras imagens quanto à vida" (SONTAG, 2004, p.122).

As atividades de campo foram realizadas num período total de dois anos, no primeiro ano foi realizada a primeira atividade de campo e no segundo ano foi realizada a oficina pedagógica com os alunos na escola, esta metodologia se assemelha com a empregada por Carvalho et al (2009).

No primeiro estágio foi identificado os conhecimentos que os alunos possuíam acerca de conceitos geográficos pré-definidos pelos Parâmetros Curriculares Nacionais para o ano escolar que estavam e posteriormente foi realizada a saída de campo em um trecho da bacia hidrográfica. No segundo estágio foi realizada a oficina pedagógica com estes alunos, em que os mesmos foram convidados a responderem uma ficha protocolo sobre as condições ambientais dos pontos em que foram realizadas as paradas.

Durante uma semana foi acompanhada a vivência dos alunos na escola, observando a rotina diária e a convivência entre alunos e professores. Neste período, foi solicitado aos responsáveis, por meio de formulários entregues aos alunos, que autorizassem os menores a participarem da atividade.

Algumas orientações para a atividade de campo foram fornecidas, tais como levar uma garrafinha com água, utilizarem bonés ou algo que os protegessem dos raios do Sol, passarem protetor solar e utilizarem bermudas, chinelos e roupas confortáveis de uma forma geral, quanto ao lanche eu fiquei encarregada de levá-lo.

A atividade de campo foi realizada com os alunos do $7^{\circ}$ ano (antiga $6^{a}$ série) do Ensino Fundamental, na escola pública Unidade Escolar Desembargador João Pacheco Cavalcante, Corrente-PI. Duas professoras se dispuseram a acompanhar a atividade.

Ainda na escola, os alunos foram divididos em duplas e foi entregue uma câmera para cada dupla. Houve uma explicação prévia onde foram abordadas algumas definições de paisagem, espaço, assoreamento e desmatamento. Após este diálogo os alunos se dirigiram à região onde seria o ponto inicial da atividade de campo, próximo do rio. Segundo os PCN (1998, p.136) "a leitura da paisagem pode ocorrer de forma direta (pela observação da paisagem de um lugar que os alunos visitaram) ou de forma indireta (por meio de fotografias, da literatura, de vídeos, de relatos) ". Partindo de tal premissa, ao chegar neste ponto, os alunos foram orientados e tirarem fotografias de fatores que julgassem estar relacionado com o assoreamento do rio e ao desmatamento da vegetação localizada na região da Área de Preservação Permanente. 
Durante este primeiro momento, em que os alunos seguiram as orientações acerca do que deveriam priorizar como foco em suas fotografias, pois "um certo direcionismo fotográfico, tanto em relação à escolha do tema quanto em relação ao ângulo, à composição e outros recursos fotográficos empregados na concepção da imagem, é inevitável” (MARTINS, 2008, p.169).

Do ponto inicial ao ponto final do percurso foram feitas 4 paradas. No percurso de volta, os alunos foram orientados a tirarem fotografias do que mais lhes chamassem a atenção na região próxima ao rio, podendo ser resultado de ação antrópica ou não. A atividade de campo durou aproximadamente $2 \mathrm{~h}$.

Simultaneamente ao processo do registro iconográfico, os alunos expunham suas experiências com a região e suas motivações para escolha de determinados locais a serem fotografados. Assim, como afirma Frigério (2013, p.31), “[...] o olhar seleciona, recorta, registra ângulos, planos e tomadas, que se tornam imagens a serem compartilhadas com outros olhares". Neste sentido, Kossoy (1989, p.101), afirma que:

O fragmento da realidade gravado na fotografia representa o congelamento do gesto e da paisagem, e portanto a perpetuação de um momento, em outras palavras, da memória: memória do indivíduo, da comunidade, dos costumes, do fato social, da paisagem urbana, na natureza. A cena registrada na imagem não se repetirá jamais. $\mathrm{O}$ momento vivido, congelado pelo registro fotográfico, é irreversível (KOSSOY, 1989, p.101).

Desta forma, a iconografia pode se configurar como ferramenta na caracterização da mudança da paisagem ao longo de processos de assoreamento. Assim, as ferramentas de Sistema de Informação Geográfica (SIG) sendo utilizadas em conjunto com a iconografia podem permitir uma visão global do processo de assoreamento desencadeado nos rios em séries analíticas temporais. Contudo, ao se analisar o meio ambiente por fotografias, não se pode esquecer que "a fotografia é o paradigma de uma relação intrinsecamente equivoca entre o eu e o mundo - sua versão da ideologia do realismo às vezes prescreve um apagamento do eu em favor do mundo, outras vezes autoriza uma atitude agressiva diante do mundo a qual celebra o eu" (SOTANG, 2004, p.140).

Para a segunda etapa de campo foi realizada uma oficina pedagógica na escola com os alunos, que consistiu na aplicação de um protocolo de análise em que os alunos 
deveriam definir notas, de acordo com o explicitado no APÊNDICE A, para cada ponto onde houve uma parada na saída de campo realizada anteriormente. "O protocolo consiste em um conjunto de parâmetros que avalia as características físicas e nível de impactos ambientais decorrentes de atividades antrópicas e as condições de habitat e nível de conservação natural..." (BERGMANN; PEDROZO, 2008, p.541).

Houve uma explicação de como preencher o protocolo, assim como uma orientação a ser seguida durante o preenchimento. O tempo médio para responder a avaliação em cada ponto de parada foi de aproximadamente $30 \mathrm{~min}$, pois as duplas discutiam entre si quais os principais elementos presentes no ponto. Assim como sugere Carvalho et al (2009), os alunos foram convidados a identificar os principais problemas encontrados em cada ponto e a proporem possíveis soluções para os problemas que eles relataram. Desta forma,

Learning and engagement preferences on how children receive instructions are affected by the predominant sensory modality which the individual prefers to approach and engage with, as well as take in new information. Their learning modalities refer to the sensory pathways (i.e. visual, auditory and kinaesthetic) through which they send, receive and store information. (MAHDJOUBI; AKPLOTSYI, 2012, p.209).

Assim, os estilos de aprendizagem estariam intimamente relacionados com os estímulos que cada aluno recebeu ao longo de sua aprendizagem e também as memórias ambientais e sociais que possuem como o meio em que vivem. Contudo, "despite these advances, learning style models have remained largely concerned with the 'educational' aspect of information, and so far have ignored the role of the environment" (MAHDJOUBI; AKPLOTSYI, 2012, p.209).

A metodologia não seguiu a visão bancária de educação ${ }^{3}$, onde, segundo Freire (2011, p.81): "Na visão "bancária" da educação, o "saber" é uma doação dos que se julgam sábios aos que julgam nada saber. Doação que se funda numa das manifestações instrumentais da ideologia da opressão - a absolutização da ignorância, que constitui o que chamamos de alienação da ignorância, segundo a qual esta se encontra sempre no outro". Consequentemente, a metodológica foi definida de forma a fazer com que os

\footnotetext{
3 “' A consciência bancária' pensa que quanto mais se dá mais de sabe". Mas a experiência revela que com este mesmo sistema só e formam indivíduos medíocres, porque não há estimulo para a criação" (FREIRE, 2008, p.38).
} 
alunos retratassem, de acordo com a sua percepção e valoração, as paisagens que mais lhes julgassem significativas dentro do tema a ser estudado.

Contudo, Kossoy (2007, p.46) defende a ideia de que não se deve esquecer que "a documentação não pode ser pensada como um documento que vale por si só próprio, neutro, isento de manipulação" as fotografias devem ser analisadas cuidadosamente para que haja o "exame crítico que a metodologia da história impõe aos documentos".

\subsection{A abordagem}

Os PCN (1998), em sua abordagem, sugerem que "o estudo da paisagem local/global não deve se restringir à mera constatação e descrição dos fenômenos que a constituem", devendo explicar-se às crianças "os processos de interações entre a sociedade e a natureza, situando-as em diferentes escalas espaciais e temporais, comparando-as, conferindo-lhes significados" (PCN, 1998, p.32).

As atividades realizadas durante esta pesquisa tentaram estabelecer ligações emocionais dos alunos como meio, pois muitas observações e constatações são mais perceptíveis nas saídas de campo e não apenas nas atividades desenvolvidas nas aulas teóricas. Outro ponto importante foi que as atividades foram realizadas em duplas e com os alunos de uma forma conjunta, fazendo com que houvesse a colaboração e disseminação das mais diversas emoções e conhecimentos que os alunos possuíam.

[...] As emoções e sensações surgidas durante a aula de campo em um ambiente natural podem auxiliar na aprendizagem dos conteúdos, à medida que os alunos recorrem a outros aspectos de sua própria condição humana, além da razão, para compreenderem os fenômenos. Mais que compreender a realidade, trata-se também de considerar as emoções como fundamentais nos processos de tomada de decisão e de julgamento moral dos seres humanos, conforme afirma Damásio (2001), e assim inferir que as emoções participam tanto dos processos de raciocínio quanto na construção de valores humanos que garantirão a forma pela qual o corpo de conhecimentos vai influir na escolha entre as soluções possíveis para a ação na vida prática (SENICIATO; CAVASSAN, 2004, p.145).

A fotografia é tratada neste estudo como "[...] um fator de introdução de um tempo prospectivo em vidas vividas como e estivessem aquém desse além fragmentariamente real e episódico do vivido [...] A fotografia, na cotidianidade, é uma das mediações materiais simbólicas do vivido" (MARTINS, 2008, p.51). Desta forma, 
As imagens fotográficas, entretanto, não se esgotam em si mesmas, pelo contrário, elas são apenas o ponto de partida, a pista para tentarmos desvendar o passado. Elas nos mostram um fragmento selecionado da aparência das coisas, das pessoas, dos fatos, tal como foram (estética/ideologicamente) congelados num dado momento de sua existência/ocorrência (KOSSOY, 2002, p.21).

Tendo como ponto de partida esta abordagem, pode-se discutir com os alunos problemas sociais e ambientais da região em que eles vivem, assim como estabelecer a identidade territorial que eles estabeleceram no momento em que estavam fotografando. Com isto, seria possível aos alunos olharem o ambiente que convivem diariamente com olhar mais crítico sobre as ações sociais e suas consequências ao meio ambiente, além de ressaltar "a capacidade da imagem em incluir 'sinais' destinados ao espectador, que lhe permitem adotar uma posição de leitura conveniente" (AUMONT, 2011, p.92). Desta forma, é preciso considerar "as crianças como atores sociais, sujeitos produtores de cultura, seres ativos situados no tempo e no espaço" (FRIGÉRIO, 2013, p.26).

Contudo, ao se utilizar a fotografia como ferramenta em uma pesquisa científica, Oliveira (2008) enumera alguns fatos que não devem ser deixados de lado, sendo eles: a fotografia é um recorte da realidade, onde não se pode ver toda a paisagem; e a cultura e a vivência do fotógrafo influenciam a tomada de decisão, ao escolher um "objeto em detrimento de outro". Diante deste contexto, a fotografia foi utilizada como um signo, com múltiplas significações em um processo que proporcionava ao educando e desconstrução do seu objeto de análise.

Assim, por meio de registros iconográficos é possível notar as mudanças ocorridas na paisagem ao longo dos anos, sejam elas urbanas ou rurais, ao mesmo tempo em que se pode documentar as fisionomias geográficas, sejam elas humanas ou físicas, e suas mudanças no tempo e espaço. 


\section{RESULTADOS E DISCUSSÕES}

Analisar as modificações na paisagem requer uma série de cuidados, pois é necessário primeiramente fazer com que a sociedade consiga perceber a sua situação existencial no meio ambiente para posteriormente mostrar-lhes as modificações que suas ações causam ao meio. Posteriormente, pode-se estabelecer diálogos desafiadores e construtivos acerca de suas ações, tentando desta forma elaborar respostas que possam ser colocadas em prática para melhorar a paisagem deteriorada.

A discussão relacionada às modificações na paisagem demanda uma elaboração de conteúdos que abordem questões sociais e ambientais, que façam com que a população tenha uma identificação com tais questões, além de gerar um conhecimento ético e político. Neste sentido, é imprescindível, quanto geógrafo e quanto cidadão consciente, estabelecer que o

Nosso papel não é falar ao povo sobre a nossa visão de mundo, ou tentar impô-la a ele, mas dialogar com ele sobre a sua e a nossa. Temos de estar convencidos de que a sua visão de mundo, que se manifesta nas várias formas de sua ação, reflete a sua situação no mundo, em que se constitui. A ação educativa e política não pode prescindir do conhecimento crítico dessa situação, sob pena de se fazer "bancária" ou de pregar no deserto (FREIRE, 2011, p.120).

A utilização das fotografias mostra a paisagem passada, "um artefato que contêm em si um quadro determinado da realidade registrado fotograficamente" (KOSSOY, 1989, p.31) e que, por este motivo, serve como uma espécie de descrição de uma determinada porção do espaço na paisagem num determinado tempo. Assim, abaixo seguem imagens de diferentes períodos da área de estudo: 
Figura 3: Área de estudo no ano de 1984.

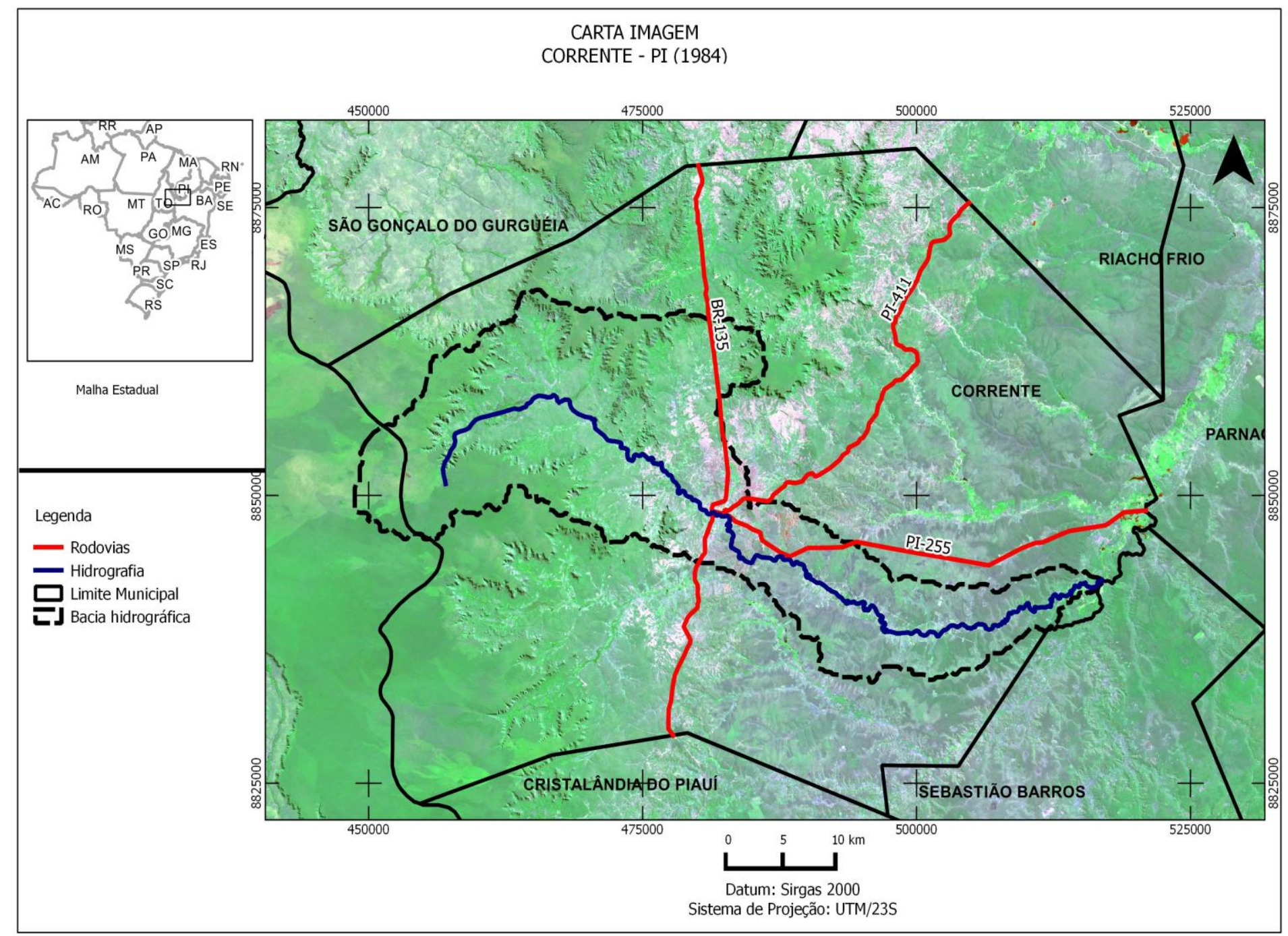

Fonte: NASCIMENTO, 2016. 
Figura 4: Área de estudo no ano de 2010.

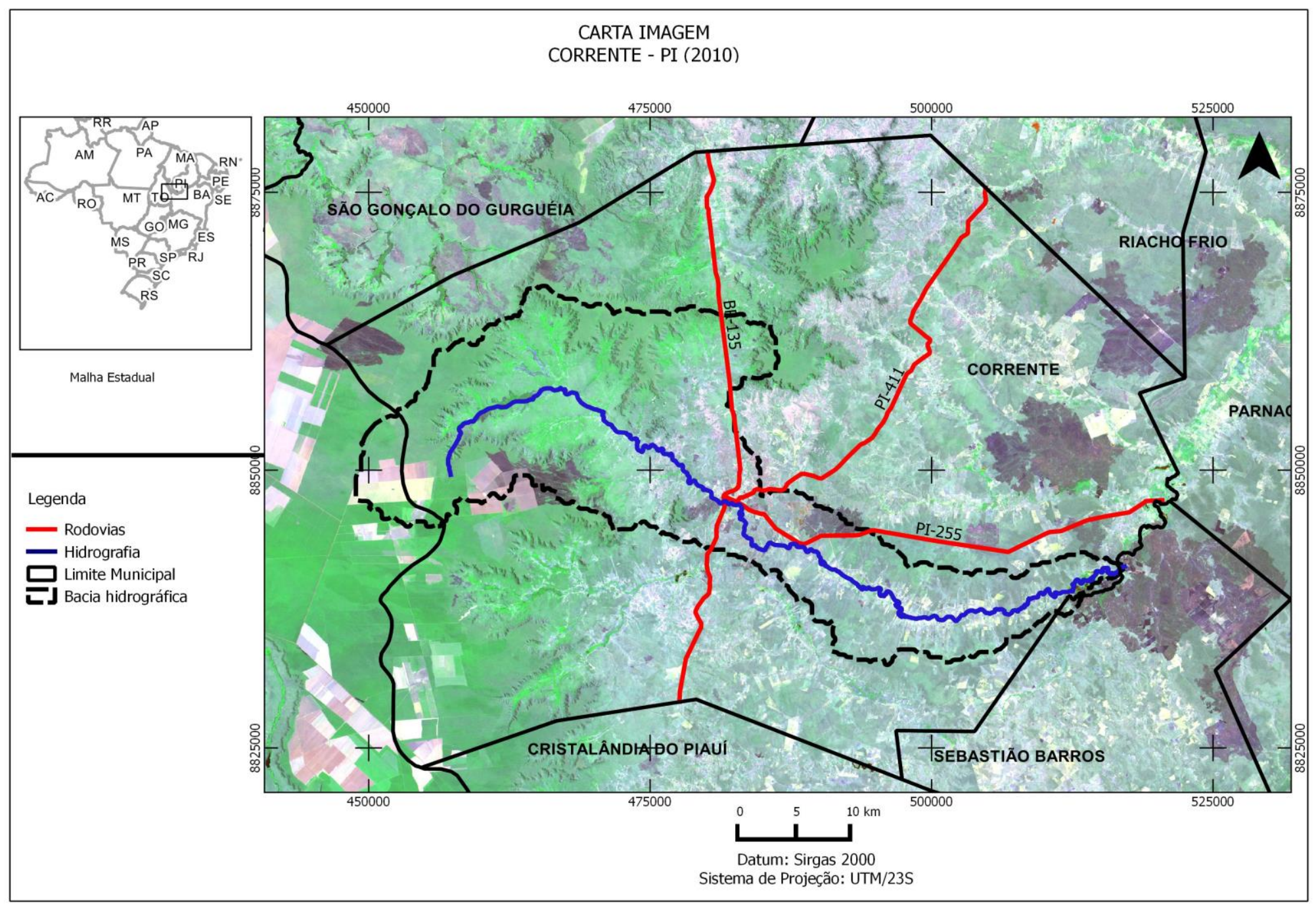

Fonte: NASCIMENTO, 2016. 
Figura 5: Uso da terra na área de estudo no ano de 1984.

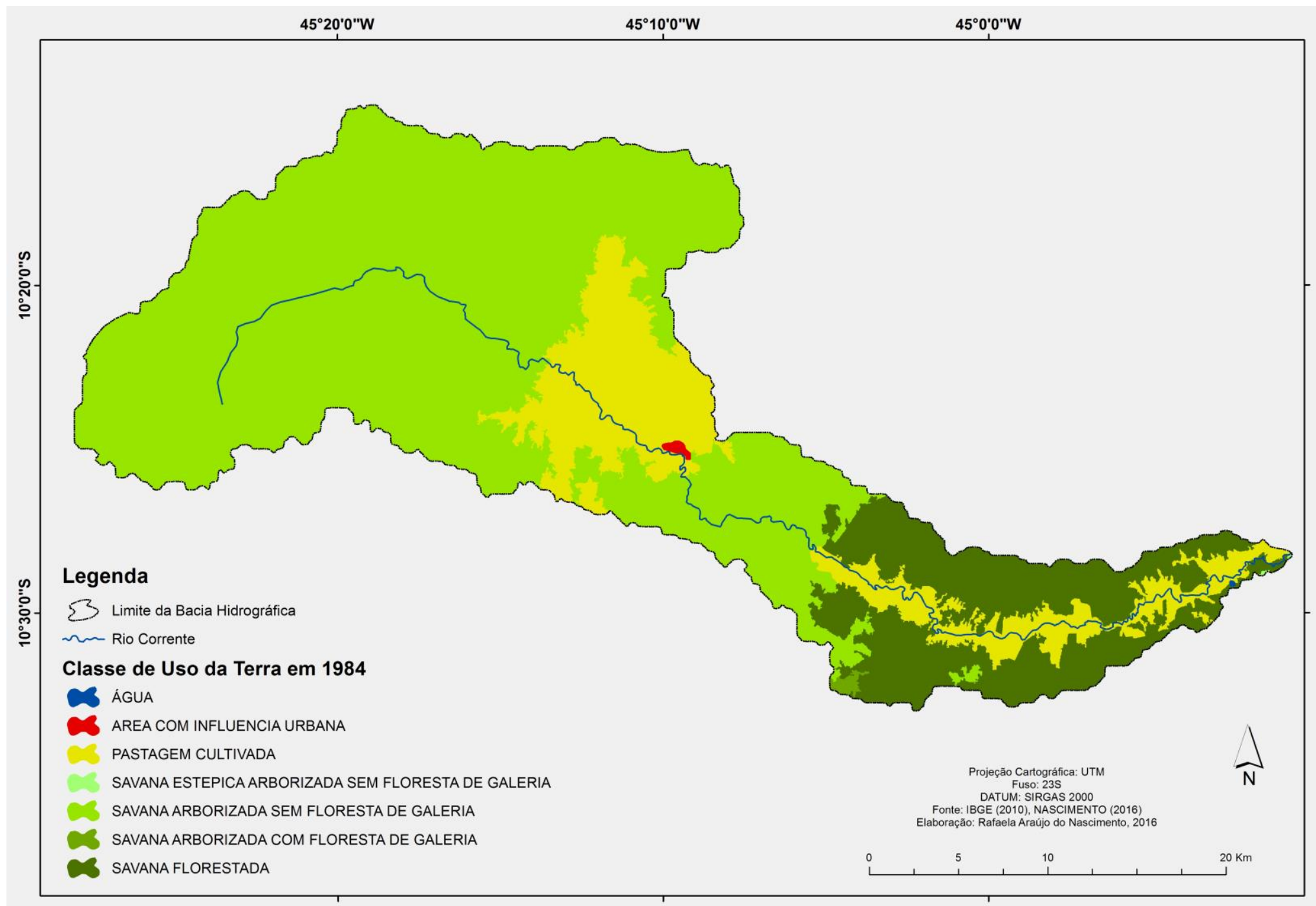


Figura 6: Uso da terra na área de estudo no ano de 2010.

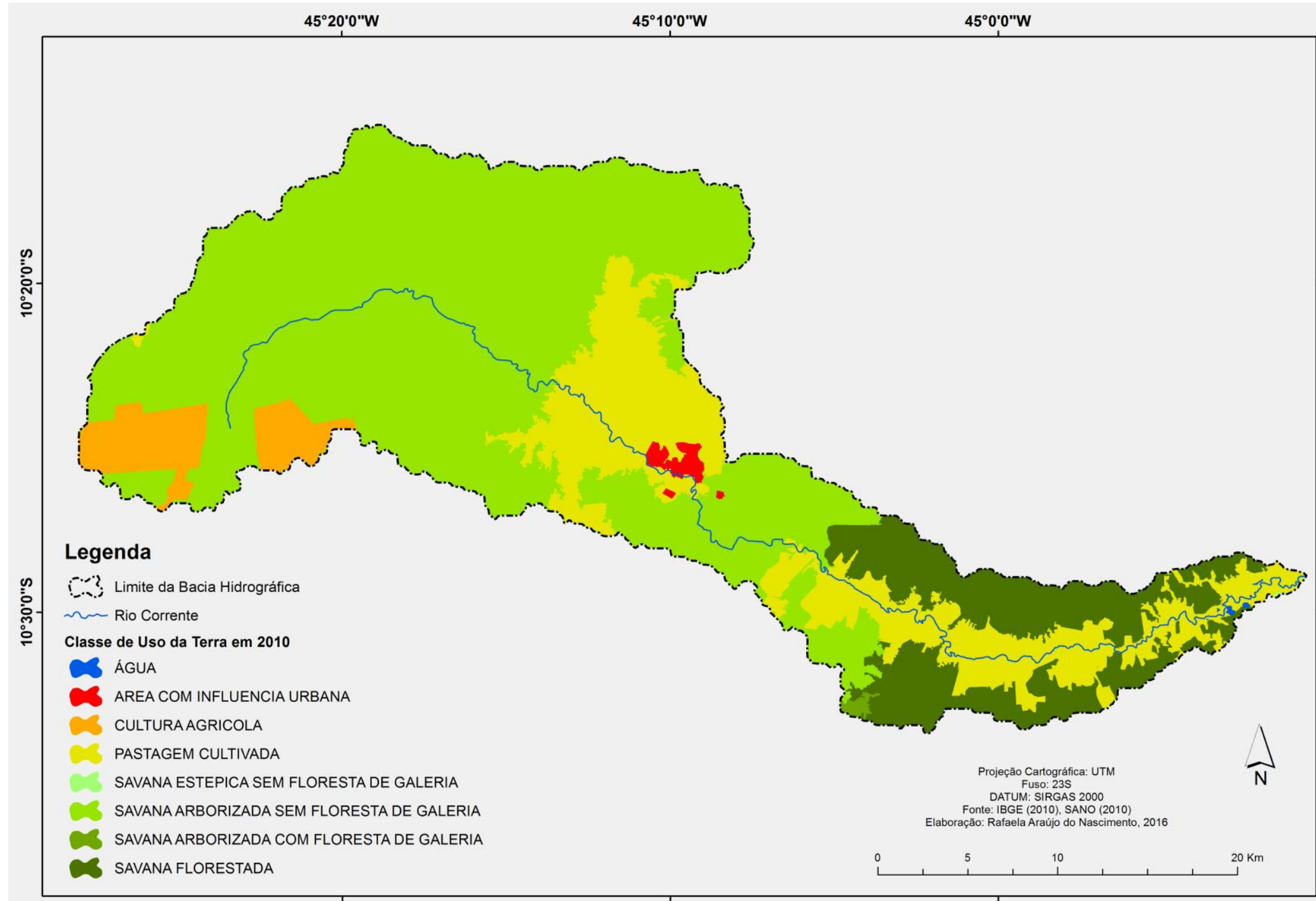


Nas figuras 3 e 5, verifica-se a presença de grandes porções de áreas verdes ainda preservadas, enquanto que nas figuras 4 e 6 nota-se a presença de diversas áreas desmatadas para plantação. $\mathrm{O}$ desmatamento concentra-se primordialmente nas regiões próximas a nascente principal do rio e nas margens do rio. Tal desmatamento se deve sobretudo a fertilidade destas áreas e a disponibilidade de água para irrigação das plantações. Nos mapas referentes ao ano de 2010, nota-se um aumento na área urbana da cidade e também um aumento da cultura agrícola presente na região.

A fotografia adquire importância científica quando a empregam de forma a mostrar os diferentes signos que existem numa paisagem. Assim, o contexto histórico e a vida social em que a paisagem pertence podem ser retratados e analisados por meio de fotografias, fazendo com que o signo oculto na fotografia e seus significados possam ser revelados por meio de suas interpretações.

Trabalhar a questão ambiental por meio de fotografias realizadas, em sua grande maioria, por alunos faz com que estes não se reduzam ao olhar mecânico, ajudando no processo de criação e no encadeamento de suas ideias e interpretações de problemas gerados por suas ações e pela sociedade em que vivem. $\mathrm{O}$ processo de investigação gerada por estes alunos faz com que seja estabelecida uma investigação crítica da realidade vivida mais do que apenas discutir os conceitos geográficos estabelecidos pelos PCN em salas de aula. Conscientizar os alunos de séries iniciais pode ajudar na proteção de ambiental de algumas áreas, pois:

No discurso da ação é necessário vigiar os comportamentos dos outros e os comportamentos próprios, porque há ainda muito pouca gente verdadeiramente sensibilizada para a proteção do ambiente (CASTRO, 2003). Neste pensamento, torna-se urgente a sensibilização dos alunos para os aspectos pró-ecológicos para que estes possam tornar-se vigilantes na proteção dos recursos naturais (CARVALHO et al, 2009).

Seniciato e Cavassan (2004) defendem a ideia de que "além dos aspectos emocionais envolvidos - e que podem ser importantes para a motivação em aprender -, as aulas de campo favorecem também uma abordagem ao mesmo tempo mais complexa e menos abstrata dos fenômenos estudados", pois fará com que os alunos interajam e vejam no dia a dia o que aprenderam nas salas de aulas.

O processo de aprendizagem, por meio de atividades externas de campo proporciona ao aluno uma inclusão em sua realidade e também faz com que este participe e se conscientize das mudanças que ocorrem no meio. 
Em outras palavras, a experiência do aluno com o conhecimento do mundo é sempre medida pelo outro, neste caso o educador, que fornece significados para os objetos de estudo à volta do aluno, dificuldades de aprendizagem ou não. Esta relação interpessoal representa a internalização da própria cultura e do conhecimento. Desse modo, parte-se da premissa que o desenvolvimento se dá de dentro para fora, com a intermediação do outro, num processo continuo de apropriação da cultura e do conhecimento. Assim, o ser humano está exposto a esta relação desde o momento do nascimento e por isso, a criança, internaliza a cultura, aprende a gesticular, emitir as principais palavras, dar nomes aos objetos e manuseá-los e colhe informações a respeito do mundo ao redor, pois o ser humano não nasce com instrumentos endógenos para seu desenvolvimento (AZEVEDO et al, 2014, p.175).

No que tange à realidade, os alunos poderiam simplesmente se submeter a realidade, mas não o fizeram. Os alunos estão acostumados com o desmatamento na área próxima ao rio, pelo fato de morarem e habitarem a região próxima a este rio, e por terem contato constante com pessoas que moram nesta região. Os questionamentos e levantamentos feitos na saída de campo mostraram o quanto eles se importam com o rio e com sua paisagem adjacente. Muitos não conseguiam perceber que casas e ruas estavam sendo construídas em áreas e locais irregulares por que muitos viviam naquela região e julgavam tais ações normais e certas. Eles não sabiam o que era uma Área de Preservação Permanente - APP, tão pouco conseguiam ver que, além de jogar lixo nas ruas e rio, outras ações poderiam ter consequências danosas a vitalidade do rio. 
Figura 7: Trajeto percorrido com os alunos.

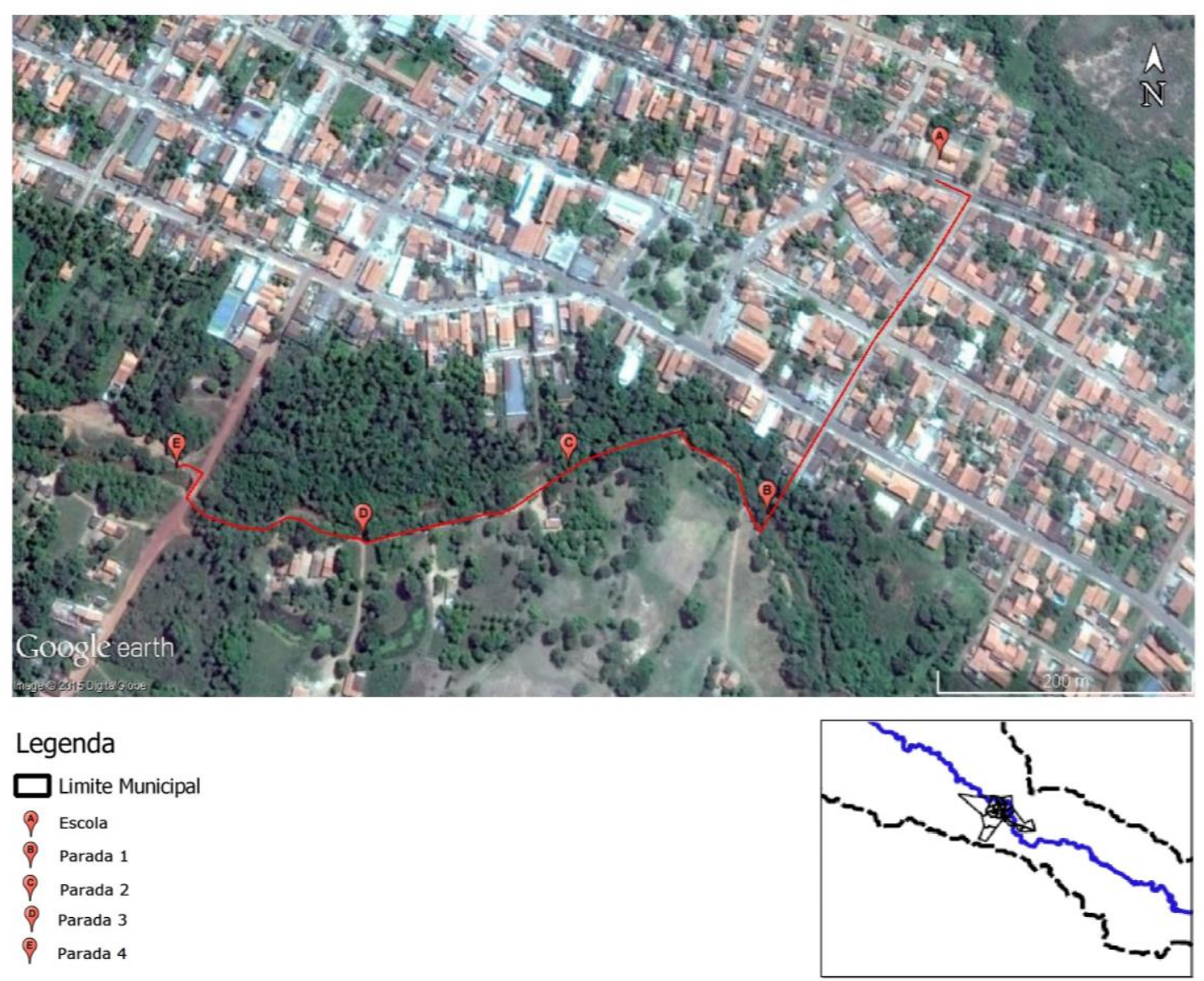

Fonte: NASCIMENTO (2016), com base no Googel Earth (2015). 
A seguir, algumas fotografias produzidas pelos alunos durante o trajeto na atividade de campo realizada no dia 18 de setembro de 2014, no período da manhã.

\section{*Parada 1 (ponto de partida próximo ao rio)}

Figura 8: Fotografia tirada na parada 1 durante o percurso de ida.

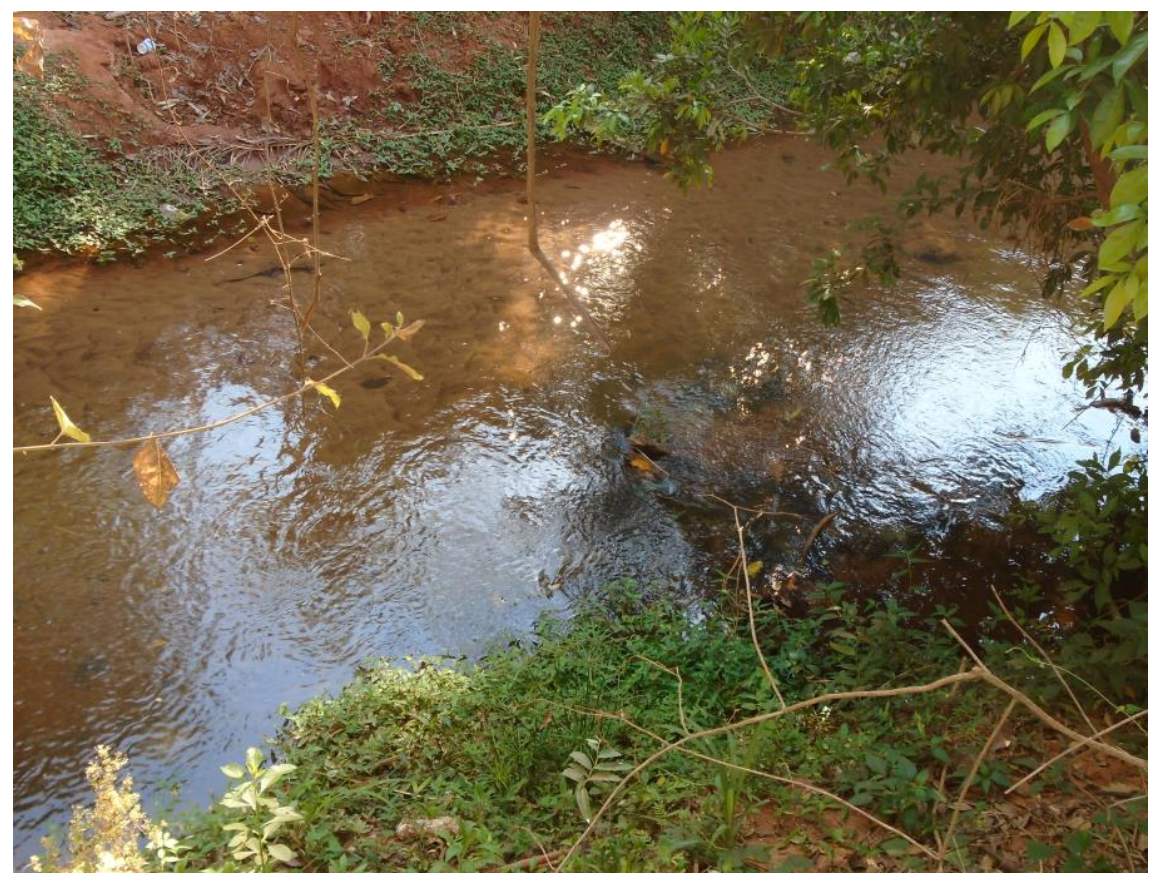

Fonte: Fotografia tirada pelos alunos Silvana e Daniel.

Ao saímos da escola, nos direcionamos à um beco que dá acesso ao rio. Lá os alunos foram orientados a tirarem fotografias dos elementos geográficos (paisagem, assoreamento, elementos antrópicos, deslizamentos, entre outros) que foram discutidos com eles na sala de aula. Posteriormente ao momento fotografado, foi solicitado a eles que explicassem a impressão que tinham da paisagem que estavam vendo.

Muitos afirmaram que "o rio está largado tia", num sentido de que este estava assoreado e sem a vitalidade de antes. Eles observaram que boa parte do leito do rio havia sido desmatado para a construção de uma estrada de terra que ligava algumas casas construídas nesta região para o centro da cidade.

As crianças descreviam que para passar pelo rio nem precisaria subir as calças porque ele não tinha água o suficiente para molhar e sujar suas roupas, alguns nem se deram ao trabalho de retirar as sandálias durante a travessia do rio. 
Figura 9: Fotografia tirada na parada 1 durante o percurso de volta.

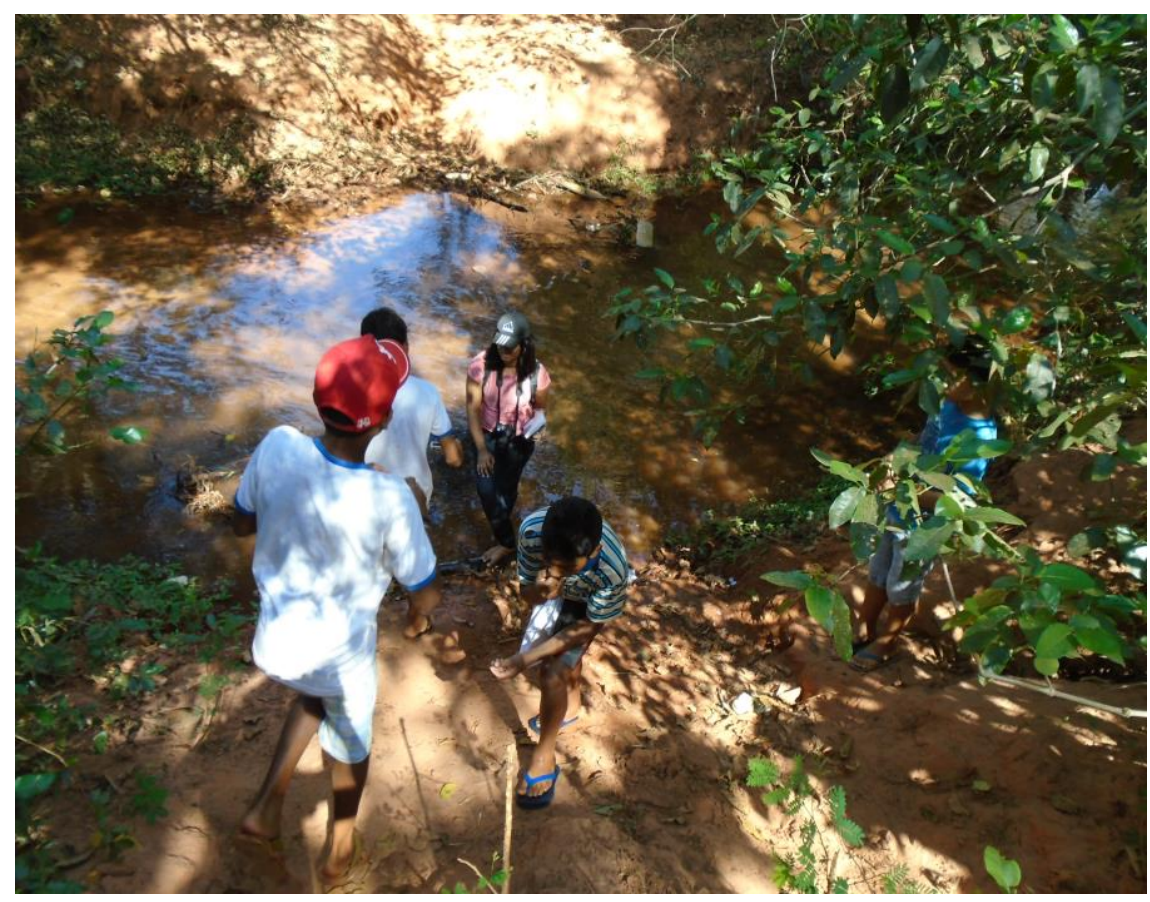

Fonte: Fotografia tirada pelos alunos Luciano e Eduardo.

$\mathrm{Na}$ volta, os alunos já estavam se sentindo mais à vontade com a minha presença e com a atividade. As brincadeiras foram inevitáveis e alguns sugeriram que eu me posicionasse próxima a eles para servir como uma "escala para mostrar o assoreamento" que havia na primeira parada. Eles afirmaram que tendo como parâmetro eles e eu, seria mais fácil poder mostrar à outras pessoas o quanto "o rio estava fino", mostrando o estreitamento do rio causado pela deposição de sedimentos em suas margens.

Ao longo da caminhada, fui conversando com os alunos e pude notar neles que este tipo de aprendizagem lhes mostrava a dualidade de imagens pensadas e que influência a representação urbana exercia sobre a percepção deles.

Na volta fui relatando a eles como era este trajeto na época em que eu morava na cidade e também fui lhes mostrando os pontos que mais haviam mudado e descrevendo como eram há aproximadamente uns 10 anos. Neste momento, pedi as professoras que estavam presentes que fossem falando de como a paisagem foi mudando ao longo do tempo em que elas tiveram os primeiros contatos com o rio. Os nossos relatos fizeram com que alguns alunos notassem que havia uma mudança nítida entre a cidade de ontem e a de hoje. 


\section{*Parada 2}

Figura 10: Fotografia tirada na parada 2 durante o percurso de ida.

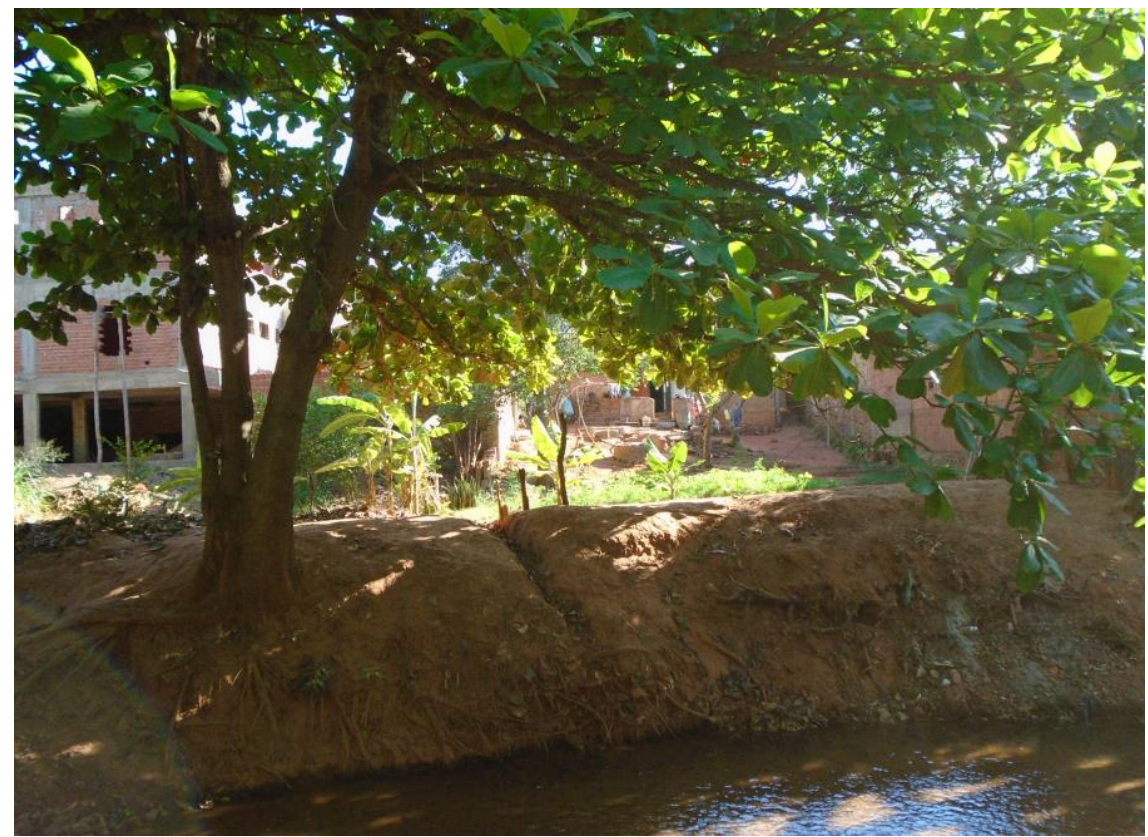

Fonte: Fotografia tirada pelos alunos Luciano e Eduardo.

Esta parada, a meu ver, foi a mais confusa para os alunos, pois muitos moram em áreas próximas ao rio e passam frequentemente por esta região. Por estarem tão imersos no meio e, mais especificamente, neste tipo de paisagem, eles não conseguiam analisar as consequências que as construções irregulares provocavam na modificação da paisagem. Neste momento, muitos se perguntavam por que não barraram as construções nesta região já que tais ocupações "matavam o rio".

Como geógrafa, me vi confusa neste momento, pois como abordar este tema com as crianças sem deixa-las culpadas ou gerar algum sentimento de descontentamento com os seus modos de ocupação, tendo em vista que estas não têm culpa destas ações sociais. O pensamento crítico delas me fez pensar e repensar, em uma forma prática e didática para aborda o tema. Então, tive que explicar a elas que algumas modificações são acentuadas pelo tempo e que não modificam a paisagem do dia para a noite, que há sim modificações danosas causadas pela ação antrópica, mas que estas não necessariamente eram culpa ou resultado de suas ações. 
Figura 11: Fotografia tirada na parada 2 durante o percurso de ida.

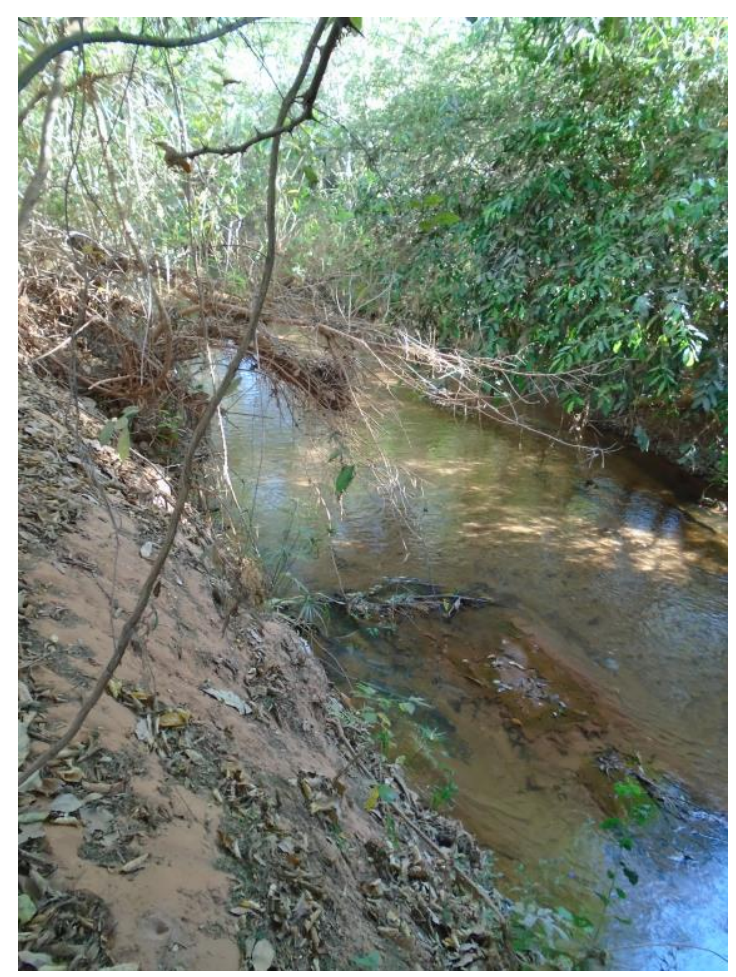

Fonte: Fotografia tirada pelos alunos Alcsander e Edimario.

Esta parada serviu para mostrar o que era o assoreamento para as crianças, pois muitas não sabiam de que se tratava este conceito. Ao mostrar o que é o assoreamento, muitas riram e falaram que viam isto constantemente no rio, mas que não saberiam identificá-lo na paisagem se não fosse esta atividade que fiz com eles.

Próximo a esta paisagem fotografada, há um esgoto que é lançado diretamente no rio. Os alunos ficaram surpresos em saber que isto acontecia ali, tão perto do centro da cidade e que, segundo eles, se o esgoto estava ali era porque ninguém fazia algo para tirar ele dali. Neste sentido, Lucatto e Talamoni (2007), afirmam que "atualmente, em todo o mundo, os rios são os corpos receptores de dejetos domésticos, agrícolas e industriais, que contaminam os ecossistemas e representam um risco para todos os seres vivo." 


\section{*Parada 3}

Figura 12: Fotografia tirada na parada 3 durante o percurso de ida.

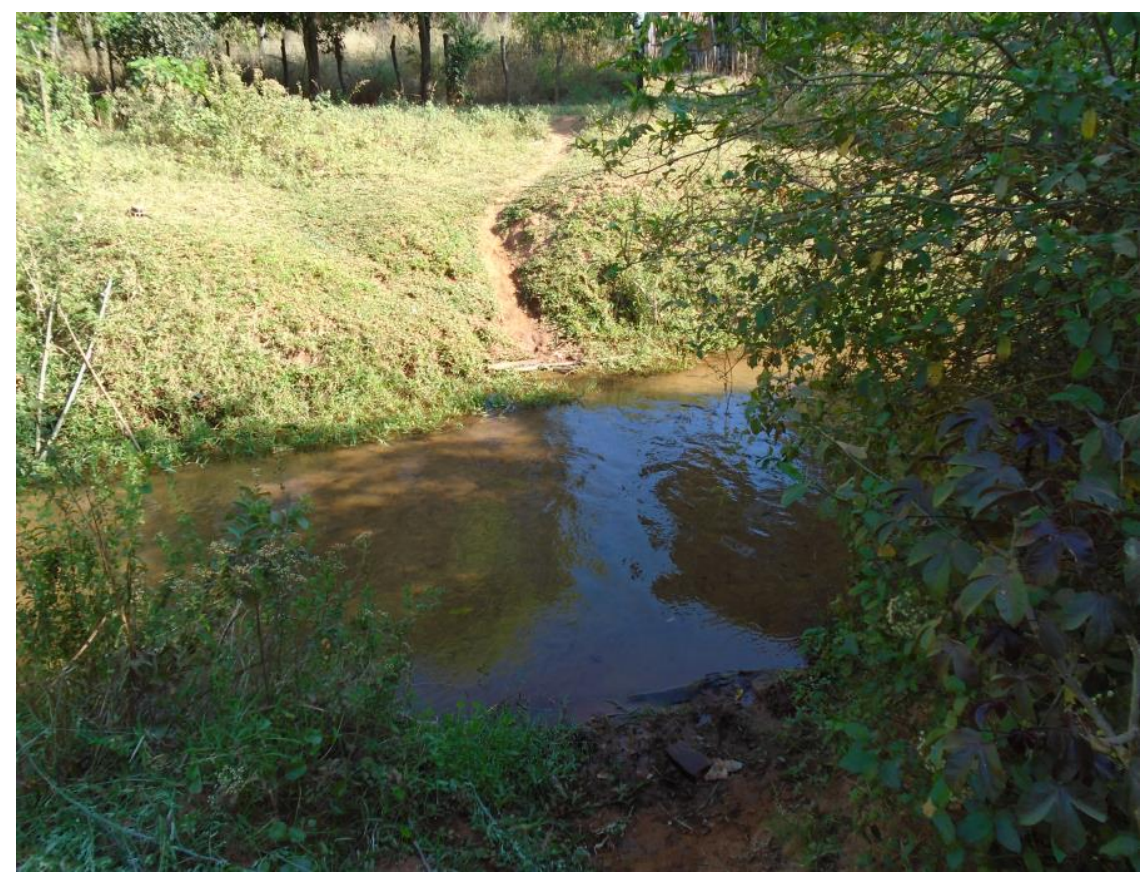

Fonte: Fotografia tirada pelas alunas Bruna e Marcela.

Ao chegar neste ponto, muitos alunos riram e começaram a correr dentro do rio. Eu os perguntei por que estavam fazendo isto e eles me mostraram que era porque precisavam chegar do outro lado para fotografar um deles que havia quase caído na lama que estava próxima a subida. Eles relataram que quando chove, isto é inevitável de acontecer e que não passam por aí neste período, mas sim pela ponte que liga o bairro Vermelhão (uma alusão ao tipo de solo vermelho encontrado no bairro, que por não possuir calçamento na maioria de suas ruas, fica vermelho de lama durante a época chuvosa) e o centro da cidade.

Neste momento, comecei a pensar nas competências e habilidades definidas pelos PCN para esta série escolar, em que eles devem reconhecer fenômenos espaciais, comparar e interpretar estes fenômenos; analisar e comparar as relações de degradação ambiental; compreender e aplicar os conceitos básicos de Geografia no dia a dia. Segundo os relatos dos alunos, esta atividade de campo facilitou a assimilação de alguns conceitos geográficos e também fez com que eles olhassem de outra forma os acontecimentos do cotidiano. 
Figura 13: Fotografia tirada na parada 3 durante o percurso de volta.

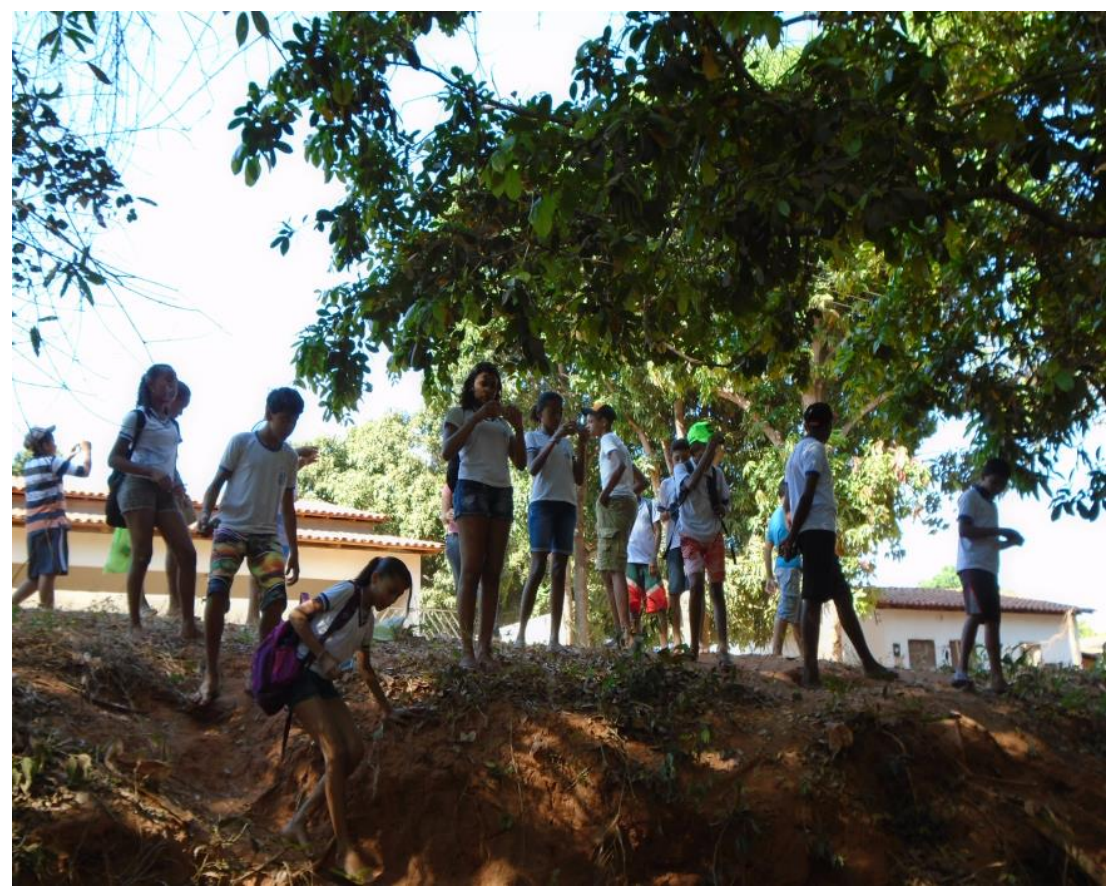

Fonte: Fotografia tirada pela autora.

O momento era de descontração entre os alunos, eles abordavam a realidade local de forma divertida e em grupo. Uma dupla tirava uma foto e mostrava a outra e vice-versa. Eu me posicionei dentro do rio para poder fotografar esta interação deles, com a paisagem e com eles mesmos.

O espaço urbano estava sendo lido de uma forma tão descontraída e leve que os alunos começaram a se perguntar o porquê de nunca terem olhado esta paisagem desta forma, um pensamento crítico sendo construído e um símbolo sendo descontruído. A intenção durante esta atividade foi justamente mostrar a eles a realidade que a maioria vê todos os dias, mas com outro olhar, o olhar de quem prática e reconhece as consequências de suas ações. A realidade criada estava sendo aos poucos descontruída. 


\section{*Parada 4}

Figura 14: Fotografia tirada na parada 4 durante o percurso de ida.

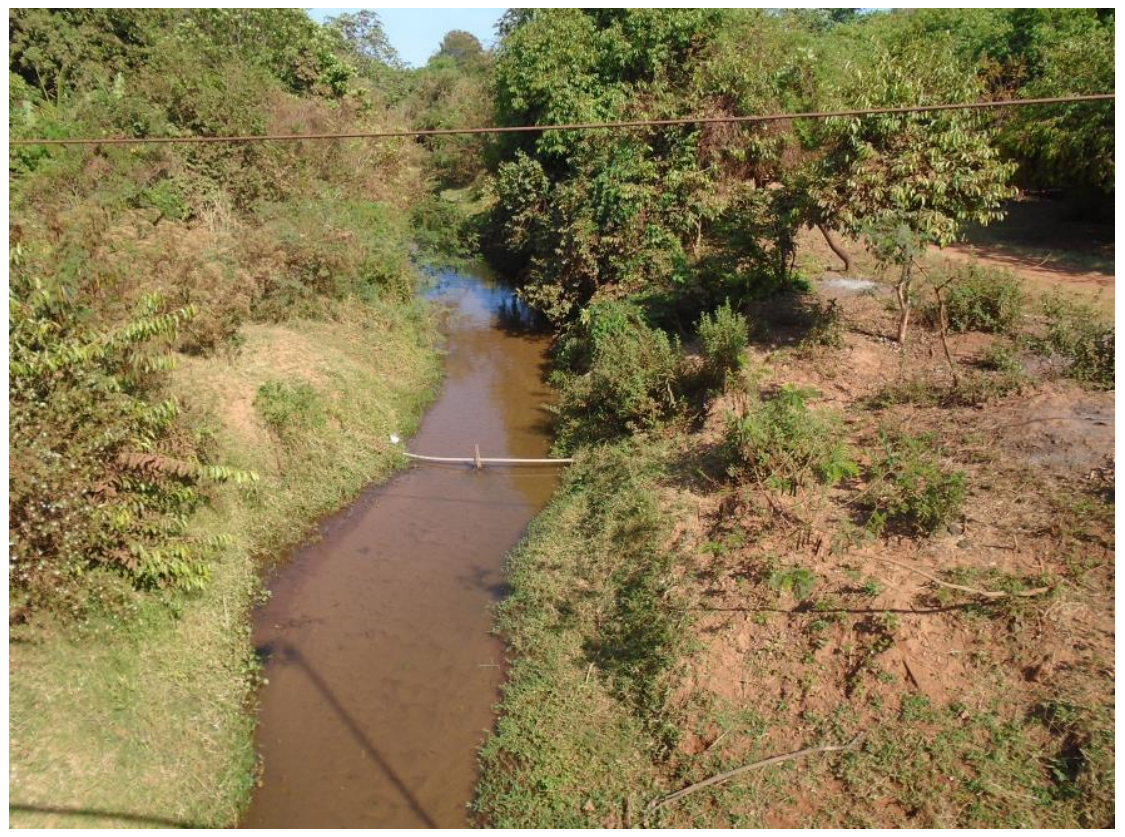

Fonte: Fotografia tirada pelos alunos Silvana e Daniel.

A última parada foi feita próxima a ponte que dá acesso do bairro Vermelhão ao centro da cidade. Neste momento os alunos focaram principalmente em tirar fotografias da largura do rio e muitos não entendiam porque o rio ainda não secou, pois muitos chamavam a atenção para o fato dele possuir pouca água, quase não ter árvores em suas margens e estar com cada vez mais areias em seu leito. Neste momento, alguns alunos se lembraram que, durante o período de chuvas na cidade, está área é a que mais fica alagada e atrapalha as pessoas a passarem de um lado da cidade para outro. Um dos alunos disse que já viu algumas pessoas que moram neste local saírem para casas de amigos e familiares com seus pertences para não perderem tudo na chuva. 
Figura 15: Fotografia tirada na parada 4 durante o percurso de volta.

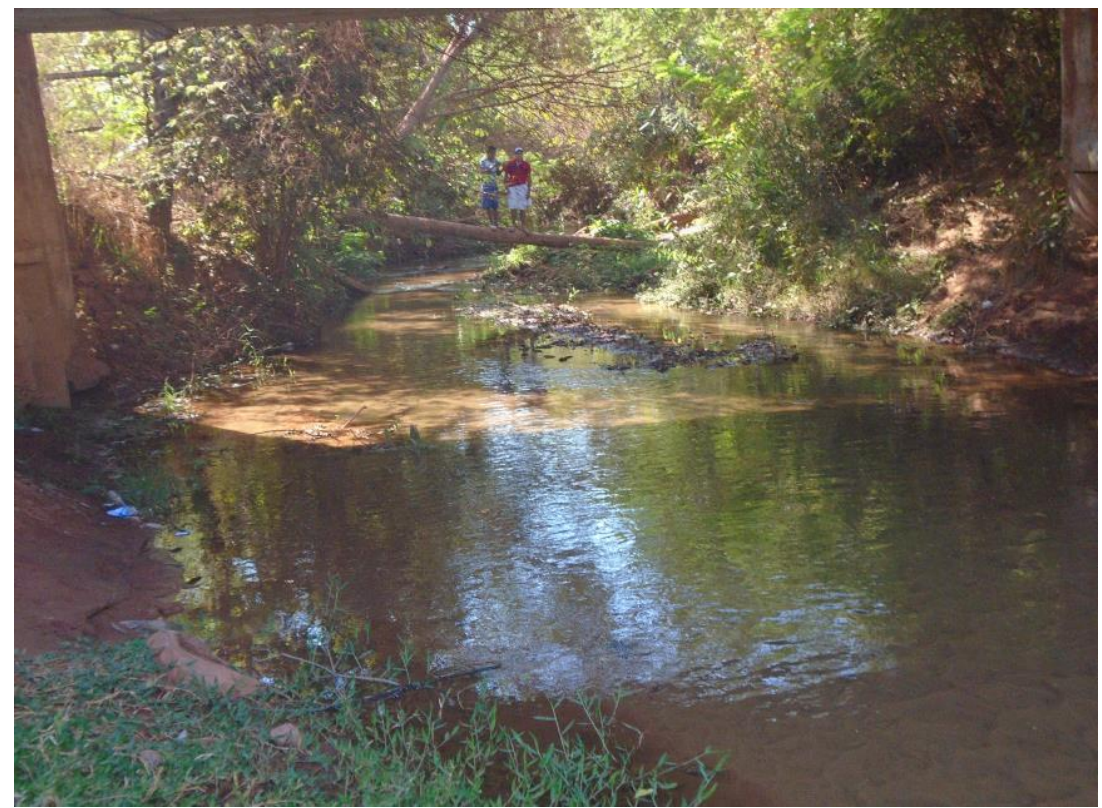

Fonte: Fotografia tirada pelos alunos Silvana e Daniel.

Ao se ambientarem com a paisagem, as crianças começaram a fazer brincadeiras e alguns chegaram a subir em uma árvore que estava caída sobre o rio. Foi inevitável pensar em brincadeiras que as crianças de uma cidade com menos de 30 mil habitantes podem fazer, principalmente por ainda terem contato com a natureza, mesmo ela tendo sofrido tantas ações antrópicas. Apesar de estarem fazendo uma atividade de campo comigo, os alunos não se esqueceram de que em primeiro lugar são crianças e que queriam aproveitar a atividade que estava sendo feita e produzida por eles, pois como diziam: "Tia, não é todo dia que paramos pra brincar por aqui. Normalmente a gente só passa, isto quando não estamos correndo pra não chegar atrasado na aula”.

Ao observá-los brincando percebi que aquele mesmo lugar que me remete tantas lembranças da infância pode, apesar de diferente, exercer influências nas crianças atuais. O meu saudosismo neste momento foi inevitável. Vê-los ali brincando, autorizados ou não por mim e pelas professoras, pude notá-los interagindo com a paisagem de uma forma tão natural, fotografando o que mais gostaram, suas brincadeiras, a paisagem e, inevitavelmente, sendo apenas crianças se divertindo em uma atividade fora da sala de aula. 
Após a aula de campo, passei um tempo conversando com os alunos sobre a atividade que realizamos, e pude notar que eles estavam usando mais os conceitos científicos e também estavam os relacionando mais com as ações antrópicas. Neste momento, pensei no que afirmam Seniciato e Cavassan (2004), "a experiência e as sensações vividas contribuem para que os alunos recorram aos aspectos concretos da realidade, guardando coerência com as características de interpretação do mundo [...] ". E assim como Mahdjoubi e Akplotsyi (2012), observei que as crianças fotografaram o que mais lhes chamaram a atenção e o que mais se identificavam na paisagem.

As fotografias, de uma forma geral, duram mais do que a modificação na paisagem real, pois a fotografia ao representar o momento vivido, o passado, é imutável, enquanto que a paisagem real está em constante transformação, seja devido a fatores sociais ou não. A fotografia permite mostrar que "o momento vivido, congelado pelo registro fotográfico, é irreversível. As personagens retratadas envelhecem e morrem, os cenários se modificam, se transfiguram e também desaparecem" (KOSSOY, 2002, p.139).

A imagem fotografada serve como uma espécie de cenário do passado, reunindo o conhecimento do passado com as possíveis análises do presente, fazendo-se entender a fotografia como um meio de representação social de uma realidade. Abaixo segue uma comparação entre duas fotografias tiradas de um mesmo lugar do rio em épocas diferentes, e visivelmente com paisagens diferentes também.

Ao conversar com pessoas mais velhas, que viveram na época em que esta fotografia foi tirada, elas afirmam que esta foto não foi tirada num período de cheia e o que rio tinha esta vazão ao longo dos períodos de seca.

[...]A fotografia é o inventário da mortalidade. Basta, agora, um toque do dedo para dotar um momento de uma ironia póstuma. As fotos mostram as pessoas incontestavelmente presentes num lugar e numa época especifica de suas vidas; agrupam pessoas e coisas que, um instante depois, se dispersaram, mudaram, seguiram o curso de seus destinos independentes [...] (SONTAG, 2004, p.85).

Estes moradores ainda relataram que os jovens costumavam descer o rio e passar por dentro destes canos, alguns acabavam ficando presos dentro dos canos e rezando para não morrerem afogados. Aos domingos, as pessoas iam tomar banho de rio, fazer piqueniques, namorar e jogar futebol nos campinhos que delimitavam à beira do rio. Muitos relatavam que seus pais não os deixavam ir sozinhos ao rio, pois tinham medo 
que eles morressem afogados ou que se machucassem nas brincadeiras. Abaixo segue uma fotografia atual desta mesma área.

Figura 16: Fotografia da área conhecida como “barragem”, aproximadamente, em 1970.

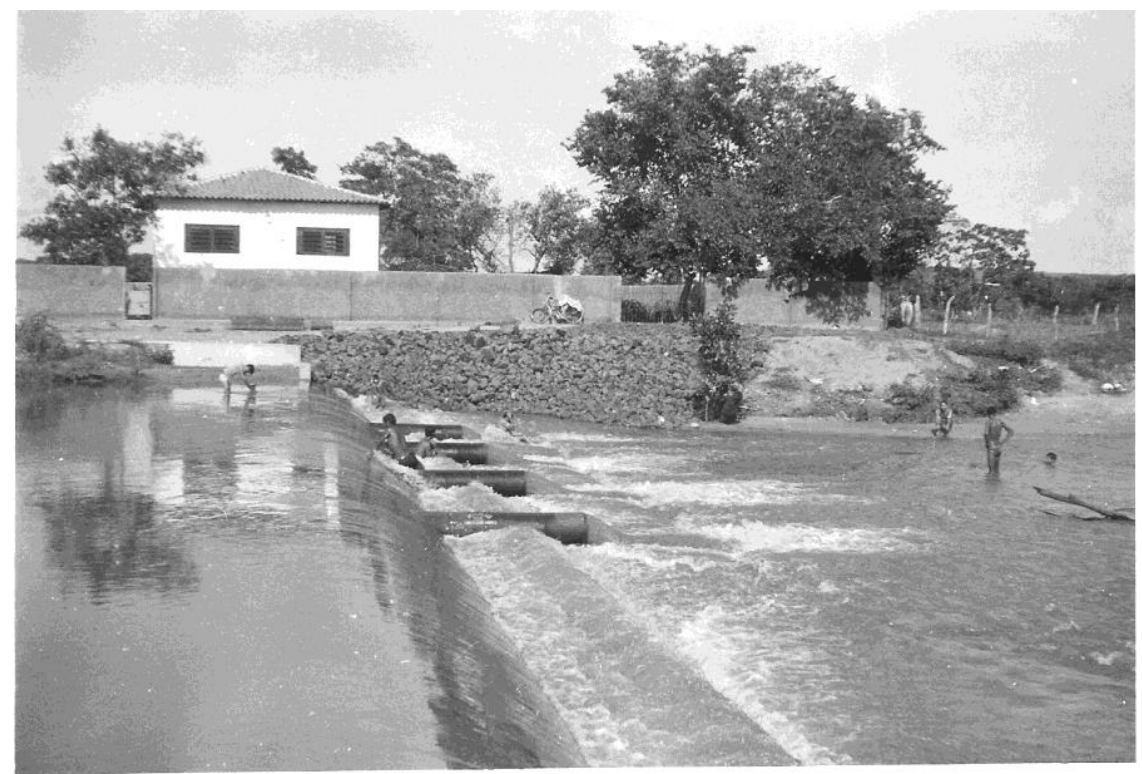

Fonte: Autor desconhecido. Imagem cedida pela Prefeitura Municipal de Corrente - PI.

Esta fotografia foi tirada na região de abastecimento de água de cidade, conhecida como barragem. As fotografias antigas podem ser classificadas como "fontes insubstituíveis para a reconstrução histórica dos cenários, das memorias de vida (individuais e coletivas), de fatos do passado centenário como do mais recente" (KOSSOY, 2002, p.133).

Figura 17: Fotografia da área conhecida como "barragem”, em 2014.

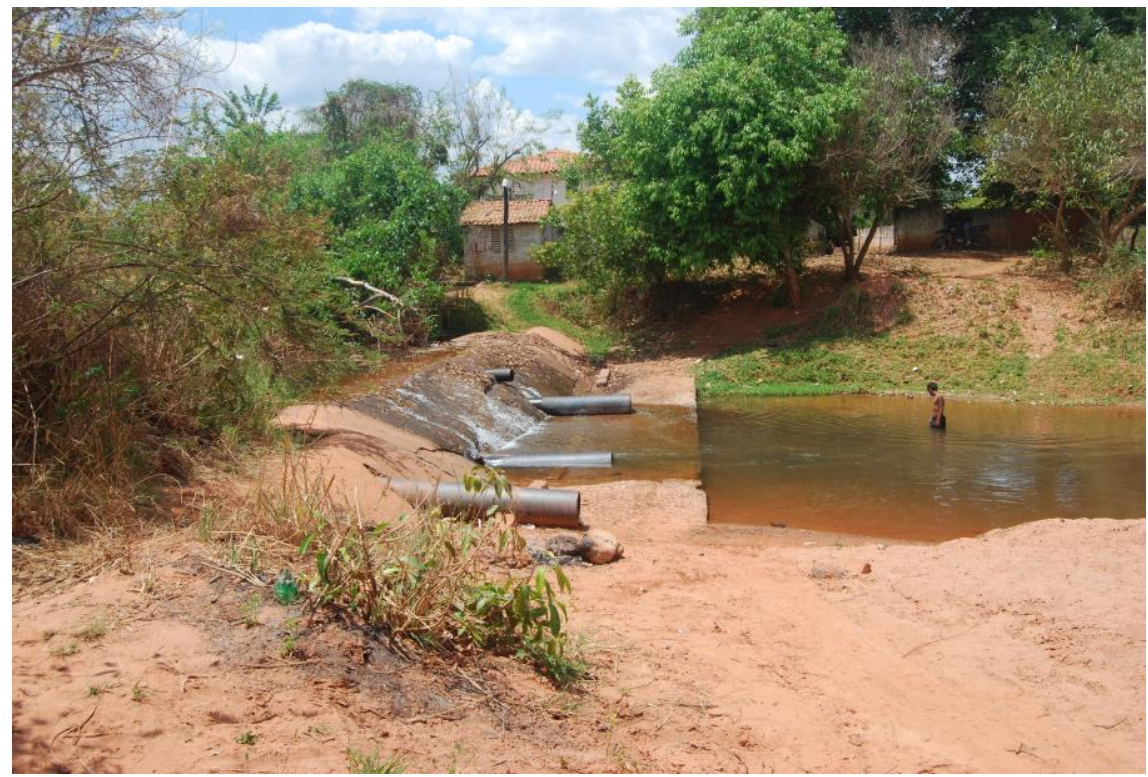

Fonte: Arquivo pessoal da autora. 
É nítido e chocante ver as mudanças nesta paisagem. Os jovens já não tomam mais tantos banhos no rio, as brincadeiras se tornam cada vez mais raras e a paisagem está cada vez mais degradada. A vazão do rio já não é mais a mesma, já não há mais tantas crianças associando sua vivência a paisagem ribeirinha.

A ocupação desordenada e a falta de preservação fazem com que cada vez mais o rio sofra com as ações antrópicas. As lembranças dos mais velhos ainda existem, mas os mais jovens, com o passar do tempo, não terão tantas lembranças a contar deste rio que antes proporcionava tantos momentos de descontração e lazer às pessoas de uma cidade que teve seu nome estabelecido por causa deste rio. "O espaço e o tempo implícito no documento fotográfico subentendem sempre um contexto histórico especifico em seus desdobramentos sociais, econômicos, políticos, culturais etc" (KOSSOY, 2002, p.26).

Analisando estas duas fotografias é inevitável não se colocar no lugar de pessoas que passaram a sua juventude brincando no rio e fazer questionamentos como: o que será que elas sentem hoje quando olham fotos assim? Será que seus filhos e netos vivenciarão alguma relação de identificação com a paisagem passada? A paisagem do presente é realmente a que a população quer que prevaleça? Será que o rio voltará a ter a vitalidade de tempos passados?

Mas o que seria o presente sem as modificações culturais e na paisagem? A paisagem sim pode, e em alguns casos deve mudar, mas quando se trata de preservar o principal rio de abastecimento da região a questão é mais complexa, pois há constantes questões a serem levadas em conta. Contudo, a principal delas é que não se pode deixar o rio morrer, olhar para o seu processo de assoreamento de forma passiva sem que haja um posicionamento crítico e um agir consciente da população.

No segundo campo, realizado no ano de 2015, com a mesma turma, foi aplicado um protocolo de avaliação das qualidades ambientais da área que foi percorrida durante a primeira atividade de campo. Esta parte da atividade foi realizada novamente em dupla e, desta vez, dentro da sala de aula dos alunos, onde lhes foram entregues uma folha contendo o protocolo de avaliação para cada dupla. Durante a atividade, foram discutidas as formas como deveriam ser preenchidas e avaliadas cada critério do protocolo.

Contudo, anteriormente a aplicação do protocolo, foi discutido com alguns professores da escola quais critérios melhor representariam a região e também a melhor 
forma de fazer os alunos entenderem, evitando usar uma linguagem muito técnica e científica. Após as adaptações sugeridas pelos professores, foi estabelecido um momento em que o protocolo deveria ser aplicado. Neste momento, os alunos se sentarem em duplas, tentando manter as mesmas duplas formadas na primeira atividade de campo ${ }^{4}$.

Abaixo seguem algumas análises feitas com base nas respostas dadas por estes alunos no protocolo.

Figura 18: Média das notas dadas pelos alunos no protocolo de avaliação, para cada parada.

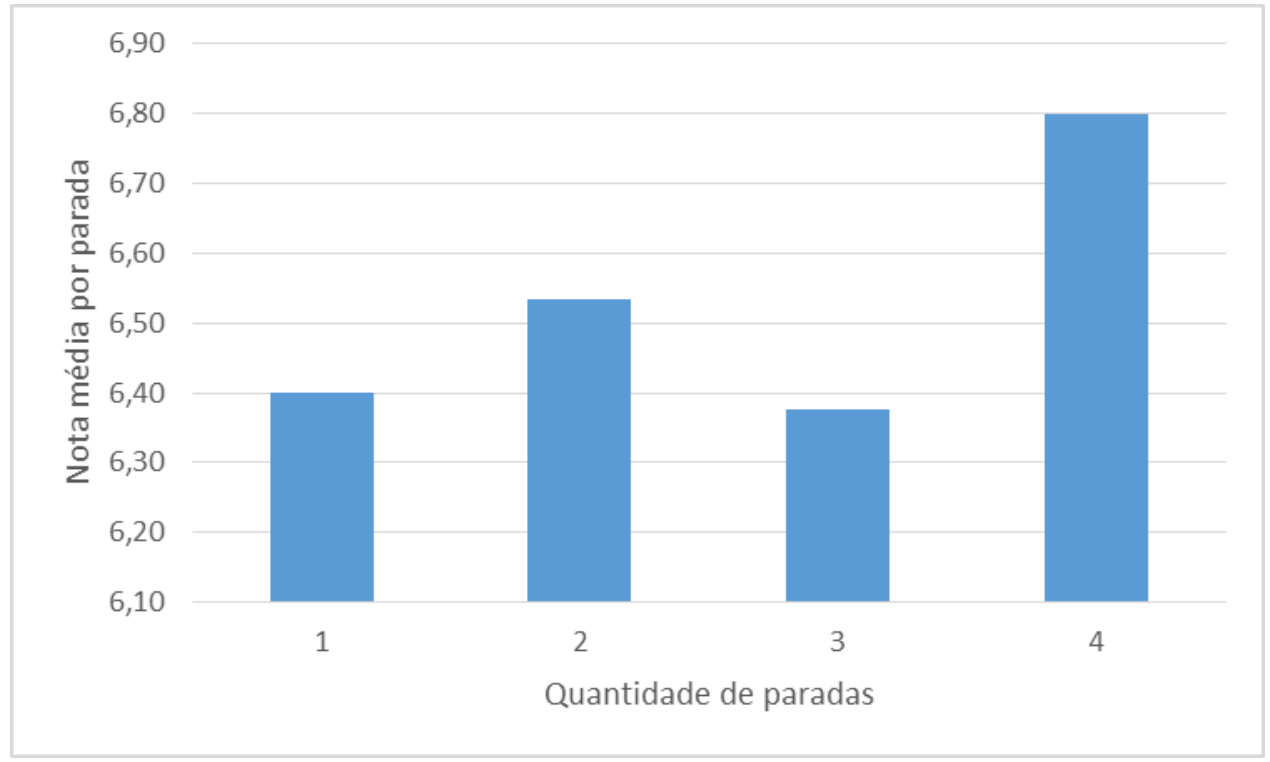

Fonte: NASCIMENTO, 2016.

A análise dos protocolos de avaliação mostrou que a parada de número 4 foi a que obteve a média mais alta das quatro, enquanto que a parada 3 foi a que obteve a média mais baixa de todas. A parada de número 4 estava localizada em uma área mais preservada, com vegetação mais fechada e o rio era mais profundo nesta área, ao contrário das outras áreas em que foram realizadas as paradas. De uma forma geral, as médias ficaram situadas entre os valores de 6 e 7, o que caracteriza este trajeto como não muito preservado e que precisa de recuperação ambiental. $\mathrm{O}$ trajeto percorrido como os alunos se deu de jusante a montante.

\footnotetext{
${ }^{4} \mathrm{Nem}$ todas as duplas foram mantidas porque dois alunos mudaram de escola e um reprovou de ano.
} 
De acordo com as análises subjetivas escritas por estes alunos em seus respectivos protocolos, é possível cruzar os dados com a quantidade de áreas preservadas que existem em cada parada. Ainda de acordo com as respostas dadas no protocolo, a quantidade de elementos antrópicos presentes em cada parada é inversamente proporcional a nota dada em cada ponto, pois quanto mais antropizados foram os elementos vistos em cada parada, menor foi a sua média.

Figura 19: Elementos naturais X Elementos antropizados fotografados na primeira saída de campo.

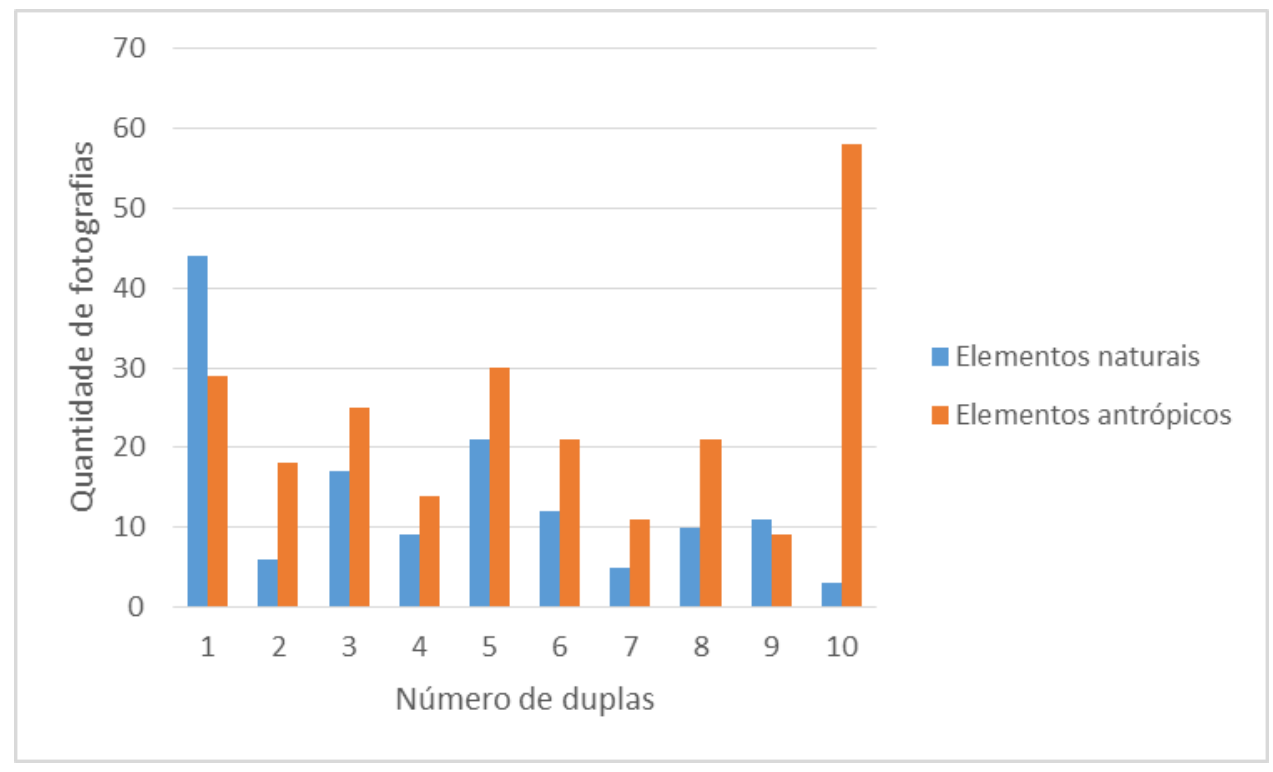

Fonte: NASCIMENTO, 2016.

Tendo como base as fotografias tiradas pelos alunos na primeira saída de campo, foram selecionadas $30 \%$ das fotos que cada dupla tirou para serem feitas as análises. A partir desta seleção, as fotografias foram analisadas de forma a separarem os elementos contidos em primeiro, segundo e terceiro plano, assim como também foram classificadas como contendo elementos antrópicos ou naturais. Com base neste gráfico, pode-se perceber que a dupla que tirou mais fotografias foi a dupla 1, assim como esta foi a que mais fotografou elementos naturais, enquanto que a dupla 10, com o segundo maior número de fotografias, foi a que menos fotografou elementos naturais.

Após a aplicação do protocolo, houve uma aula expositiva com estes alunos, onde foram convidados todos os alunos da escola. Os alunos, que participaram das atividades de campo, preparam apresentações ligadas a preservação ambiental, voltada principalmente para a preservação do rio Corrente. 
Na apresentação, estes alunos utilizaram os mapas que levei para a escola e, usando pincéis, foram riscando os mapas para mostrar aos demais presentes as localizações das áreas mais degradadas, onde fica a nascente do rio, onde se encontra o município de Corrente com relação a outras localidades próximas. Assim como aproveitaram para mostrar o caminho que percorriam para chegarem à escola.

Em um segundo momento, os alunos mostraram aos presentes algumas fotografias impressas, selecionadas por mim para a aplicação do protocolo, e uma apresentação digital que montaram com as fotografias da atividade de campo. Ao mostrarem as fotografias que eles mesmos tiraram, pude notar o quanto eles se divertiam em expor os seus trabalhos e o quanto isto estava sendo importante para eles, pois alguns, em suas exposições, chegavam a afirmar que seriam ambientalistas para cuidar da cidade e melhorar a qualidade ambiental e de vida da população correntina. A emoção transmitida pelos alunos durante a exposição dos trabalhos me fez pensar no fato de estarem envolvidos emocionalmente com o ambiente e com a forma com que foi abordado o assunto.

Figura 20: Alunos após a exposição dos trabalhos.

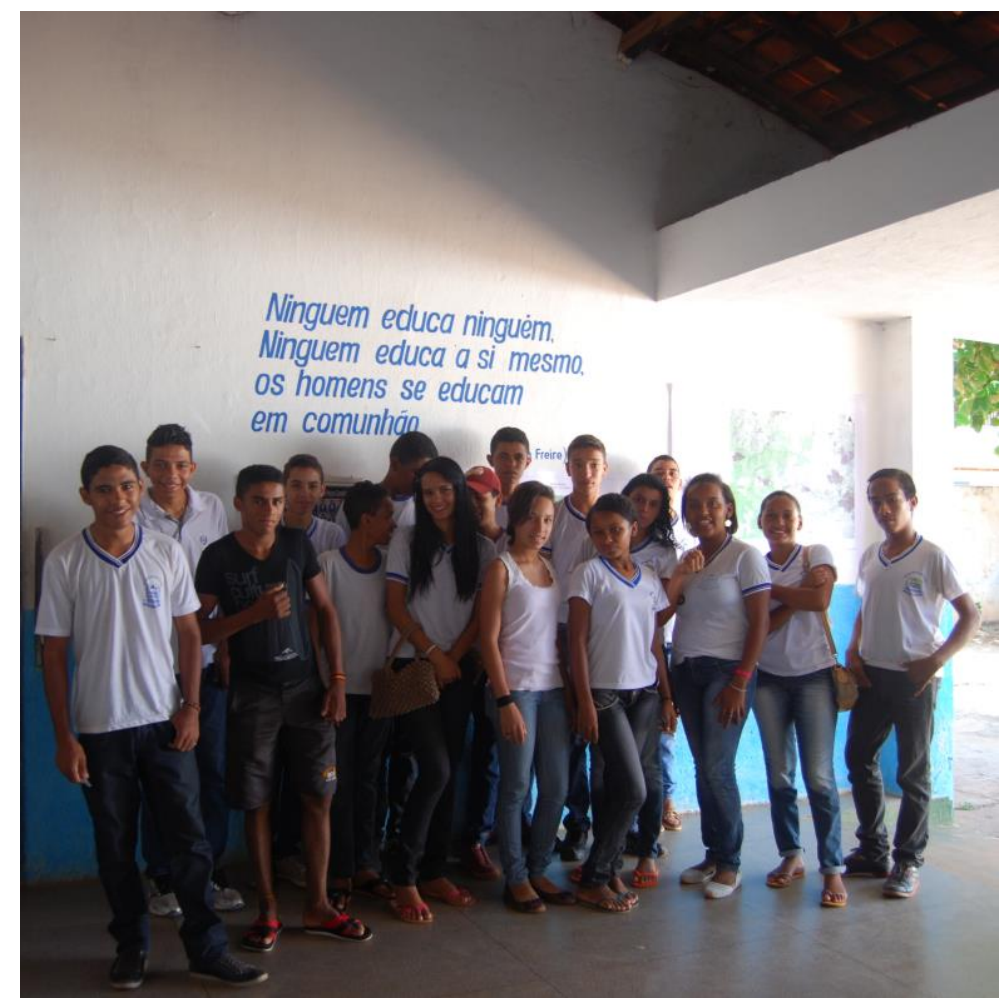

Fonte: Arquivo pessoal da autora.

A metodologia desta pesquisa, fazendo principalmente com que os alunos participassem das atividades, não como meros observadores, mas como seres dotados de 
conhecimento e vontades e vivências próprias, permitiu que fosse feita uma pesquisa que integrasse o conhecimento ensinado nas salas de aulas com aspectos inter e transdisciplinares na questão da modificação da paisagem, principalmente no que tange a paisagem urbana da bacia hidrográfica do rio Corrente. Esta pesquisa-ação mostra que é possível ter temas geradores que representem questões reais sendo discutidas e contextualizadas em salas de aula e atividades de campo, principalmente aquelas que mostram os elementos que foram discutidos em sala. Mostra ainda que há a necessidade de interação entre os alunos, os cidadãos, os professores e a comunidade escolar como um todo para que sejam discutidos temas de interesse comum, como é o caso da preservação do principal rio que abastece a cidade e para que haja a integração de alunos de séries iniciais do ensino na discussão de questões que também lhes dizem respeito.

\subsection{Considerações finais}

As fotografias produzidas por crianças mostram um olhar diferente, chegando a ser em certos pontos, até mais poético e romantizado que a de adultos. As crianças possuem um olhar diferente dos adultos, o cotidiano delas é diferente e o seu sentimento de pertencer a um dado local ou não, depende da relação de vivência que eles estabelecem com o meio. Uma criança pode passar diversas vezes por uma mesma paisagem, mas se não estabelecem uma relação de olhar-espectador com esta, não se sentem à vontade para interagir.

A presente pesquisa fez com que alguns professores mudassem a forma como abordavam alguns temas em suas aulas, como foi o caso das disciplinas relacionadas ao meio ambiente. Os professores relataram que gostaram de ver os alunos interessados por temas tão relevantes naquela localidade, de verem os questionamentos envolvendo teoria e prática, e a relação entre política e qualidade de vida sendo desenvolvidos naqueles alunos.

Nas fotografias, as crianças exprimem os seus sentimentos, a construção de seus símbolos e o recorte espacial que mais lhe chamam a atenção. Por meio das fotografias, é possível ver o seu repertório informal e que "é o repertório informacional que nos permite ver/interpretar a experiência e encontrar, no diagrama dos nossos juízos perceptivos, uma possibilidade de representação indutiva da experiência ou das hipóteses abdutivas apenas prováveis" (FERRARA, 1993, p.164). 
A investigação temática proposta nesta pesquisa tenta mostrar que crianças também percebem as modificações na paisagem, algumas de forma mais científicas que outras. Mas sobretudo, as crianças têm a liberdade de investigar as questões ambientais de uma forma mais próxima e, em alguns momentos, de forma crítica.

O educador deve ter em mente que algumas crianças não têm contato com abordagens científicas e que a temática deve ser abordada de uma maneira mais suave e branda. "A única dimensão que se supõe devam ter os investigadores, neste marco no qual se movem, que se espera se faça comum aos homens cuja temática se busca investigar, é a da percepção crítica de sua realidade, que implica um método correto de aproximação do concreto para desvelá-lo" (FREIRE, 2011, p.145), as crianças devem ser orientadas a terem questionamentos acerca de sua realidade, mas justamente por serem crianças, podem não ter uma definição clara de realidade social e ambiental.

Os alunos que participaram neste estudo, apresentaram alguns problemas ambientais que viram na área selecionada para a saída de campo, mostraram alguns elementos ecológicos que ainda estão presentes na área e, na escola, mostraram aos demais membros da comunidade escolar a relação estabelecida entre o conhecimento já existente nas salas de aula e aquelas novas informações que foram adquiridas com as atividades desenvolvidas nesta pesquisa.

As informações coletadas e geradas durante este trabalho nos permitem concluir que a situação do rio Corrente é preocupante, principalmente pelo fato de ele já estar seco em trechos que antes corria água corrente e com grande vazão. Alguns moradores de áreas rurais relataram que o rio não tem mais água para matar a cede dos animais de criação, como bovinos e equinos, e que só conseguem água para beber com a abertura de cisternas, bombas de água instaladas em trechos específicos do rio ou pela ajuda da Prefeitura no envio de água por meio dos carros pipas. No perímetro urbano, os moradores ainda não passam por situações deste tipo, mas se não forem preservadas as margens do rio e, consequentemente, as suas zonas de amortecimento, é bem provável que daqui alguns anos o rio não tenha vazão suficiente para matar a cede da população correntina.

A desconstrução dos signos e símbolos estabelecidos pelas crianças é um dos principais fatores a serem levados em conta durante as análises das fotografias, pois por estarem inseridas em seu objeto de estudo, elas podem não ter uma visão clara das consequências de suas ações. 
Algumas fotografias fazem com que o espectador viaje em seus pensamentos, sua experiência de vida, suas lembranças e seus questionamentos. A paisagem fotografada remete às lembranças que irão reconstituir vivências nos pensamentos de quem a analisa, "trata-se de um exercício mental de reconstituição quase que intuitivo" (KOSSOY, 2002, p.132).

O momento histórico representado se torna importante para o estabelecimento de significados, o fragmento visual provoca uma identidade cuja reflexão será centrada no conteúdo fotografado e no contexto histórico desta. O tempo faz com que a fotografia seja vista como um

[...] Conjunto narrativo de histórias, e não como mero fragmento imagético, se propõe como memória dos dilaceramentos, das rupturas, dos abismos e distanciamentos, como recordação do impossível, do que ao ficou e não retornará. Memória das perdas. Memória desejada e indesejada. Memória do que opõe a sociedade moderna à sociedade tradicional, memória do comunitário que não dura, que não permanece. Memória de uma sociedade de perdas sociais continuas e constitutivas, de uma sociedade que precisa ser recriada todos os dias, de uma sociedade mais de estranhamentos do que de afetos (MARTINS, 2008, p.45).

Quanto ao tempo, este é o grande responsável por tornar revelável as análises por meio das fotografias, pois "todo amanhã se crua num ontem, através de um hoje. De modo que o nosso futuro baseia-se no passado e se corporifica no presente. Temos de saber o que fomos e o que somos, para saber o que seremos" (FREIRE, 2008, p.33). As fotografias mostram que não há um processo de análise primário nem final, há apenas a interpretação de uma fotografia, de uma paisagem e de um olhar fotográfico. Trabalhar a fotografia com crianças mostra o quão interessante pode ser o olhar que estas possuem sobre o mundo com o qual tem contato, podendo, em muitos casos, mostrar um olhar que os adultos não possuem sobre uma mesma paisagem. 


\section{REFERÊNCIAS BIBLIOGRÁFICAS}

AUMONT, J. A imagem; Tradução: Estela dos Santos Abreu e Cláudio C. Santoro. Campinas, SP: Papirus, 1993. - (Coleção Ofício de Arte e Forma). 16a edição, 2011.

AZEVEDO, L. D. de. POTENCIALIDADES NARRATIVAS DE FOTO-GRAFIAS DE CIDADE. Revista Brasileira de Educação Geográfica, Campinas, v. 3, n. 6, p. 142157, jul./dez., 2013.

BARROS, M. C. M. S. Memória e representação social: o REAJA em Vitória da Conquista/Bahia (1997-2002). In: Educação e formação de professores: questões contemporâneas/ Ada Augusta Celestina Bezerra e Merilene Batista da Cruz Nascimento [organizadoras]. - Fortaleza: Edições UFC, 2013. 368 p.:il. Isbn 978.857282-576-4.

BERGMANN, M.; PEDROZO, C. da S. Explorando a bacia hidrográfica na escola: contribuições à educação ambiental. Ciência \& Educação, v. 14, n. 3, p. 537-53, 2008.

BERTRAND, G. Paisagem e geografia física global: esboço metodológico. RA'E GA O Espaço Geográfico em Análise, Curitiba, n. 8, p. 141-152, 2004. Disponível em: < http://ojs.c3sl.ufpr.br/ojs2/index.php/raega/article/view/3389/2718>. Acesso em: 14 out. 2013.

BEZERRA, A. A. C. Fundamentos e trajetória da obra. In: Educação e formação de professores: questões comteporâneas/ Ada Augusta Celestina Bezerra e Merilene Batista da Cruz Nascimento [organizadoras]. - Fortaleza: Edições UFC, 2013. 368 p.:il. Isbn $978.85-7282-576-4$.

BIGNANTE, E. Geografia e ricerca visuale. Strumenti e metodi. Finito di stampare nel maggio 2011. SEDIT - Bari (Italy). Per conta dela. Gius. Laterza \&Figli Spa.

BRASIL. Secretaria de Educação Fundamental. Parâmetros curriculares nacionais: introdução aos parâmetros curriculares nacionais / Secretaria de Educação Fundamental. - Brasília: MEC/SEF, 1997. 126p.

BRASIL. MEC. Secretaria do Ensino Fundamental. Parâmetros curriculares nacionais: Geografia. Brasília: MEC/SEF, 1998. 
Parâmetros curriculares nacionais: história. Brasília: MEC/SEF, 1998.

BRASIL. Parâmetros Curriculares Nacionais. Parte IV - Ciências Humanas e suas Tecnologias. Secretaria de Educação Média e Tecnológica. MEC/SEF, 2000.75 p.

BRASIL. Parâmetros Curriculares Nacionais. Orientações Educacionais Complementares aos Parâmetros Curriculares Nacionais. Secretaria de Educação Média. MEC/SEF, 2006. 101 p.

BRITTO, M.C.; FERREIRA, C.C.M. Paisagem e as diferentes abordagens geográficas. Revista de Geografia, Juiz de Fora, v.1, n.2, p. 1-10, 2011.

CLAVAL, P. A geografia cultural. Florianópolis: UFSC, 2011.

CAETANO, J. N.; BEZZI, M. L. Reflexões na geografia cultural: a materialidade e a imaterialidade da cultura. In. Soc. \&Nat., Uberlândia, ano 23, n.3, 453-466, set/dez. 2011.

CALLISTO, M; FERREIRA, W. R.; MORENO, P.; GOULART, M. \& PETRUCIO, M. Aplicação de um protocolo de avaliação rápida da diversidade de habitats em atividades de ensino e pesquisa (MG-RJ), Acta Limnol, Brasil, 14(1), 91-98, 2002.

CALLAI, H. C. Aprendendo a ler o mundo: a Geografia nos anos iniciais do Ensino Fundamental. Cad. Cedes, Campinas, vol. 25, n. 66, p. 227-247, maio/ago. 2005. Disponível em <http://www.cedes.unicamp.br>.

CALLAI, H. C.; MORAES, C. M.M. de. Educar para a formação cidadã na escola. XIII Coloquio Internacional de Geocrítica. El control del espacio y los espacios de control, Barcelona, 5-10 de mayo de 2014.

CARVALHO, E. M. de; ROCHA, V. S.; MISSIRIAN, G. L. B. Percepção ambiental e sensibilização de alunos do Ensino Fundamental para preservação da mata ciliar. E Rev. eletrônica Mestr. Educ. Ambient. ISSN 1517-1256, v. 23, julho a dezembro de 2009. ISSN 1517-1256

CAVALCANTI, L. de S. Cotidiano, mediação pedagógica e formação de conceitos: uma contribuição de Vygotsky ao ensino de geografia. Cad. Cedes, Campinas, vol. 25, n. 66, p. 185-207, maio/ago. 2005. Disponível em <http://www.cedes.unicamp.br>. 
CENSO DEMOGRÁFICO 2010. Características da população e dos domicílios: resultados do universo. Rio de Janeiro: IBGE, 2011. Disponível em: < http://www.cidades.ibge.gov.br/xtras/perfil.php?lang=\&codmun=220290\&search=piaui| corrente>. Acesso em: jun. 2015.

CHRISTOFOLETTI, A., 1936. Análise de Sistemas em Geografia - Introdução: Antônio Christofoletti. - São Paulo - HUCITEC: Ed. Da Universidade de São Paulo, 1979. (Geografia, teoria e realidade).

CHRISTOFOLETTI, A., 1936. Geomorfologia. São Paulo, Edgar Blücher, $2^{a}$ edição, 1980.

CLAVAL, P. A Geografia Cultural. Florianópolis, Editora da UFSC, 1999.

CORRÊA, R. L. Espaço: um conceito-chave da Geografia. In: Geografia conceitos e temas/organizado por Elias de Castro, Paulo Cesar da Costa Gomes, Roberto Lobato Corrêa. - Rio de Janeiro: Bertrand Brasil, 1995.

COSGROVE, D. E. Social formation and symbolic landscape. Originally published: London: Croom Helm, c1984, in series: Croom Helm historical geography series. With new introd. Includes bibliographical references and index. Copyright 1984, 1998 by Denis E. Cosgrove.

COSTA, E. B. Paisagem-Memória e Função Social da Fotografia. In: Geografia e fotografia: apontamentos teóricos e metodológicos / Organizadores: Valdir Adilson Steinke, Dante Flávio Reis Júnior, Everaldo Batista Costa. - Brasília: Laboratório de Geoiconografia e Multimídia - LAGIM, UnB, 2014.

DELVAL, J. Educación básica de niños, jovens y adultos: requisites para una educación substantivamente democrática. In: Educação e formação de professores: questões comteporâneas/ Ada Augusta Celestina Bezerra e Merilene Batista da Cruz Nascimento [organizadoras]. - Fortaleza: Edições UFC, 2013. 368 p.:il. Isbn 978.857282-576-4.

FERRARA, L. D. Olhar Periférico: Informação, Linguagem, Percepção Ambiental. São Paulo: Editora da Universidade de São Paulo, 1993. ISBN: 85-314-0117-8. 
FIORIN, José Luiz. Introdução à Linguística I: objetos teóricos. São Paulo: Contexto, 2002.

FREIRE, P. Pedagogia da autonomia: saberes necessários à pratica educativa. São Paulo: Paz e Terra, 1996 (Coleção Leitura). ISBN 85-219-0243-3.

FREIRE, P. Educação e mudança. Tradução de Moacir Gadotti e Lillian Lopes Martin. - Rio de Janeiro: Paz e terra, 1979. Coleção Educação e Comunicação vol. 1. Impresso no Brasil em 2008.

FREIRE, P. Pedagogia do Oprimido. 50 ed. rev. e atual. - Rio de Janeiro: Paz e terra, 2011.ISBN 978-85-7753-164-6.

FRIGÉRIO, R. C. MUNDO-RUA: conceito fotografado por crianças. In. Revista Brasileira de Educação Geográfica, Campinas, v. 3, n. 6, p. 25-46, jul./dez., 2013.

KOSSOY, B. Fotografia e história. São Paulo: Ática, 1989. 110 p. (Série Princípios; 176). ISBN 8508035187.

KOSSOY, B. Realidades e Ficções na Trama Fotográfica. Cotia, SP. Ateliê Editorial, 2002. $3^{\mathrm{a}}$ edição.

KOSSOY, B. Os tempos da fotografia: o efêmero e o perpétuo. - Cotia, SP: Ateliê Editorial, 2007.

LA BLACHE, V. DE ; JOSEPH P. M.; MARTONNE, E. Principes de geographie humaine. Paris: Armand Colin, 1941.

LA TORRE, S. de. Didática Evolucionista: passado, presente e future. In: Didática e formação de professors: perspectivas e inovacoes/ organizadoras Marilza Vanessa Rosa Suanno, Núria Rajadell Puiggrós. Goiânia: CEPED. Publicações e PUC Goiás, 2012.

LINEHAN, J. R.; GROSS, M. Back to the future, back to basics: the social ecology of landscapes and the future of landscape planning. Landscape and Urban Planning 42 (1998) $207 \pm 223$. 
LOPES, C. S.; PONTUSCHKA, N. N. O conhecimento pedagógico do conteúdo na prática profissional de professores de geografia. GEOUSP - Espaço e Tempo, São Paulo, v. 19, n. 1, p. 076 - 092, 2015.

Disponível em: http://www.revistas.usp.br/geousp/article/view/79809

LUCATTO, L. G.; TALAMONI, J. L. B. A construção coletiva interdisciplinar em educação ambiental no Ensino Médio: microbacia hidrográfica do Ribeirão dos Peixes como tema gerador. Ciência \& Educação, v. 13, n. 3, p. 389-398, 2007.

MAGALHÃES, J. P. de. Os professores, de novo pensados, em contexto de mudança. In: Educação e formação de professores: questões comteporâneas/ Ada Augusta Celestina Bezerra e Merilene Batista da Cruz Nascimento [organizadoras]. - Fortaleza: Edições UFC, 2013. 368 p.:il. Isbn 978.85-7282-576-4.

MAHDJOUBI, L.; AKPLOTSYI, R. The impact of sensory learning modalities on children's sensitivity to sensory cues in the perception of their school environment. Journal of Environmental Psychology 32 (2012) 208 e 215.

MANÉIA, A.; KROHLING, A. Transversalidade, meio ambiente e sustentabilidade na formação do educando. Rev. Elet. em Gestão, Educação e Tecnologia Ambiental (eISSN: 2236-1170). v(7), nº 7, p. 1540-1554, MAR-AGO, 2012.

MARTINS, J. de S. Sociologia da fotografia e da imagem. - São Paulo: Contexto, 2008.

OLIVEIRA, R. F. de; KUNZ, S. A. da S. Tecnologias de informação no ensino de geografia. In. Geografia em questão, v.07, n. 02, pág. 136-161, 2014. ISSN 2178-0234.

REIS JÚNIOR, D. F. Aspectos históricos da fotografia e realizações em Geografia. In: In: Geografia e fotografia: apontamentos teóricos e metodológicos / Organizadores: Valdir Adilson Steinke, Dante Flávio Reis Júnior, Everaldo Batista Costa. - Brasília: Laboratório de Geoiconografia e Multimídia - LAGIM, UnB, 2014.

RITTER, C.; GAGE, W. L. Comparative Geography. Review by: The North American Review Vol. 101, No. 208 (Jul., 1865), pp. 267-269. Published by: University of Northern Iowa. Stable URL: http://www.jstor.org/stable/25107841. Page Count: 3 
RODRIGUES, M. E. de C.; MACHADO, M. M. Vivenciando o referencial freiriano na universidade. In: Revista Linhas críticas, Brasília, DF, v.18, n.37, p.485-503, set/dez. 2012.

ROSSEL, N. C. Paulo Freire está vivo no movimento da educação popular.in: Revista Linhas Críticas, Brasília-DF, v.18, n.37, p.449-463, set/dez. 2012.

SAITO, C. H.; LUNARDI, D. G.; PORTO, C. B.; GERMANOS, E.; SAITO, I. T.; BARBOSA, R. G. Imagem e território como ponto de partida para uma educação ambiental dialógico problematizadora. Espaço \& Geografia, Vol.15, No 2 (2012), 491:516. ISSN: 1516-9375

SAITO, C. H. "Cocô na praia, não!" - Educação ambiental, ensino de ciências e lutas populares. AMBIENT. EDUC. Rio Grande, 4:45-47, 1999.

SANO, E. E.; ROSA, R.; BRITO, J. L. S.; FERREIRA, L. G.. Mapeamento do uso do solo e cobertura vegetal - bioma cerrado: ano base 2002 - Brasília:MMA/SBF, 2010. 96 p.;il. Color.: 29cm. (Série Biodiversidade, 36).

SANTANA, E.; GUEDES, J. T.; SANTANA, G. da C.. Temas transversais e prática docente: um estudo no Ensino Médio. In: Educação e formação de professores: questões comteporâneas/ Ada Augusta Celestina Bezerra e Merilene Batista da Cruz Nascimento [organizadoras]. - Fortaleza: Edições UFC, 2013. 368 p.:il. Isbn 978.85-7282-576-4.

SANTOS, B. S. dos; ANTUNES, D. D. Formação docente: processos motivacionais e subjetividade. In: Educação e formação de professores: questões comteporâneas/ Ada Augusta Celestina Bezerra e Merilene Batista da Cruz Nascimento [organizadoras]. Fortaleza: Edições UFC, 2013. 368 p.:il. Isbn 978.85-7282-576-4.

SAUER, O. A morfologia da paisagem. In: CORRÊA; ROZENDAHL (Orgs.). Paisagem tempo e cultura, Rio de Janeiro: EdUERJ, 1998.

SAUSSURE, Ferdinand de. Natureza do signo lingüístico. In Curso de Lingüística geral São Paulo: Cultrix,2008.

SCHIER, R. A. Trajetórias do conceito de paisagem na geografia. Editora UFPR. R. RA'E GA, Curitiba, n. 7, p. 79-85, 2003. 
SENICIATO, T.; CAVASSAN, O. Aulas de campo em ambientes naturais e aprendizagem em ciências - um estudo com alunos do Ensino Fundamental. Ciência \& Educação, v. 10, n. 1, p. 133-147, 2004.

SERVIÇO GEOLÓGICO DO BRASIL - CPRM. 2004. Disponível em <http://www.cprm.gov.br/rehi/atlas/piaui/relatorios/001.pdf $>$. Acesso em: 10 març. 2015.

SHAW, D. J. B.; OLDFIELD, J. D.. Landscape Science: A Russian GeographicalTradition. Annals of the Association of American Geographers, 97(1), 2007, pp. 111-126 r 2007 by Association of American Geographers Initial submission, December 2004; revised submission, July 2005; final acceptance, July 2006 Published by Blackwell Publishing, 350 Main Street, Malden, MA 02148, and 9600 Garsington Road, Oxford OX4 2DQ, U.K.

SILVEIRA, E.L.D. Paisagem: um conceito chave na Geografia. EGAL-12o Encontro. 2009.

SONTAG, S. Sobre fotografia. 1933. Tradução Rubens Fiqueiredo. - São Paulo: Companhia das Letras, 2004.

SOUZA, H. R. de; SOUZA, L. C. T. de. Outro olhar sobre o lugar: manejar as lentes para redescobrir o espaço vivido. Revista Brasileira de Educação Geográfica, Campinas, v. 3, n. 6, p. 105-123, jul./dez., 2013.

STEINKE, V. A.; Imagem e Geografia: o protagonismo da "fotogeografia". In: Geografia e fotografia: apontamentos teóricos e metodológicos / Organizadores: Valdir Adilson Steinke, Dante Flávio Reis Júnior, Everaldo Batista Costa. - Brasília: Laboratório de Geoiconografia e Multimídia - LAGIM, UnB, 2014.

SUANNO, M. V. R. Reorganização do Trabalho Docentena Educação Superior: inovações didáticas. In: Didática e formação de professors: perspectivas e inovacoes/ organizadoras Marilza Vanessa Rosa Suanno, Núria Rajadell Puiggrós. Goiânia: CEPED. Publicações e PUC Goiás, 2012. 
TURRI, E. A paisagem como teatro - do território vivido ao território representado. In: SERRÃO. A. V. Filosofia da Paisagem: uma antologia. Lisboa: Ed. Centro de Filosofia da Universidade de Lisboa. 2011.

VALENCIA, M. R.; CARO, M. A. T.; GRANDA, F. H. G. Reidentificación de la fotografia com una práctica pedagógica: configuración del concepto Lugafot. In. Revista Brasileira de Educação Geográfica, Campinas, v. 3, n. 6, p. 47-67, jul./dez., 2013. 
APÊNDICE A - PROTOCOLO DE AVALIAÇÃo

\begin{tabular}{|l|l|l|l|l|}
\hline \multicolumn{2}{|l|}{ Nomes da dupla: } \\
\cline { 2 - 4 }
\end{tabular}




\section{APÊNDICE B - PLANO DE AULA DA PRIMEIRA SAÍDA DE CAMPO}

- TEMA DA AULA: Modificações na paisagem, seja por questões antrópicas ou naturais;

- OBJETIVOS: Discutir com os alunos conceitos geográficos que, pela série que estão, deveriam ter conhecimento. Mostrar por meio de uma saída de campo estes elementos na natureza;

- DURAÇÃO: No máximo duas horas de saída de campo;

- OS RECURSOS: Garrafas com água, laches, protetor solar, câmeras fotográficas e bloco de anotações;

- METODOLOGIA: Primeiro será feita uma discussão, em sala de aula, sobre os conceitos chaves que serão observados no campo. Posteriormente serão fornecidas as instruções para a atividade de campo, divisão das duplas e distribuição das câmeras fotográficas que cada dupla irá usar no campo;

- AVALIAÇÃO: Após a saída de campo voltar para a escola com os alunos e saber suas principais impressões sobre a atividade de campo e sobre as observações que foram feitas durante as fotografias. 


\section{APÊNDICE C - PLANO DE AULA DA SEGUNDA SAÍDA DE CAMPO}

- TEMA DA AULA: Aplicação do protocolo de avaliação referente a primeira saída de campo com os alunos. Posteriormente marcar uma exposição dos trabalhos em que os alunos possam expressar as suas conclusões e avaliações sobre todas as atividades que eles participaram;

- OBJETIVOS: Verificar se os alunos de fato notaram as modificações na paisagem, para tanto será aplicado o protocoloco de avaliação e fazer com que os alunos interajam com os demais membros da sociedade sobre as questões ambientais.

- A DURAÇÃO: Para a aplicação do protocolo de avaliação duas aulas e para a aula expositiva uma manhã.

- OS RECURSOS: Fotografias impressas, protocolo de avaliação impresso para cada dupla, projetor digital para expor as fotografias e mapas para durante a exposição dos alunos e notebook.

- A METODOLOGIA: Discutir com os professores da escola o protocolo a ser aplicado com os alunos, fazer adaptações se for o caso; aplicar o protocolo com os alunos explicando o que deve ser observado em cada questionamento das paradas que foram realizadas na primeira saída de campo; conversar com os alunos sobre a aula expositiva e ajudá-los no que precisarem; marcar a aula expositiva e chamar os responsáveis de cada aluno;

- A AVALIAÇÃO: analisar os protocolos e a aula expositiva, assim como a impressão dos alunos acerca das atividades realizadas. 


\section{APÊNDICE D - AUTORIZAÇÃO DE USO DE IMAGEM, SOM DE VOZ, NOME E DEPOIMENTO}

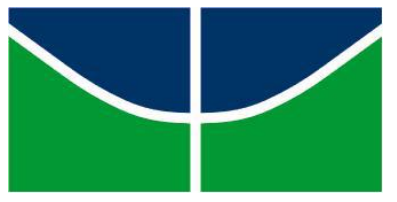

Universidade de Brasília

Instituto de Ciências Humanas

Departamento de Geografia

Laboratório de Geoiconografia e Multimídias - LAGIM

$\mathrm{Eu}$, responsáve

1 pelo(a) aluno(a) autorizo o uso da imagem do(a) aluno(a) supracitado(a), som da sua voz, nome e depoimento por ele (ela) concedido e qualquer material entre fotos e imagens, para compor o acervo do Laboratório de Geoiconografia e Multimídia - LAGIM, com sede no Campus da Universidade de Brasília - Darcy Ribeiro, Ala Norte, Módulo 23, Subsolo.

As imagens, som da sua voz, depoimentos, entre outros, poderão ser utilizados em todo e qualquer projeto e/ou obra com fins educativos, acadêmicos, científicos, sócio-culturais, tecnológicos, entre outros, sem qualquer ônus ao LAGIM ou a terceiros por este expressamente autorizado em todo território nacional e no exterior.

A presente autorização abrange os usos acima indicados tanto em mídia impressa (livros, catálogos, revista, jornal, entre outros) como também em mídia eletrônica (programas de rádio, podcasts, vídeos e filmes para televisão aberta e/ou fechada, documentários para cinema, internet, televisão, entre outros).

As obras que utilizarem as imagens, sons, nomes e depoimentos da presente autorização, poderão ser disponibilizadas, a exclusivo critério do LAGIM.

Por esta ser a expressão da minha vontade declaro que autorizo o uso acima descrito sem que nada haja a ser reclamado a título de direitos conexos a imagem, som de voz, ou a qualquer outro do(a) aluno(a) o qual sou responsável, e assino a presente autorização.

Corrente-PI, de de 2014.

Assinatura do(a) Responsável

\begin{tabular}{|l}
\hline Nome: \\
\hline Endereço: \\
\hline Cidade: \\
\hline RG N$^{\mathbf{0}}:$ \\
\hline
\end{tabular}

